NBER WORKING PAPER SERIES

\title{
INTERNATIONAL PRICE-FIXING CARTELS \\ AND DEVELOPING COUNTRIES: A DISCUSSION OF EFFECTS AND POLICY REMEDIES
}

\author{
Margaret Levenstein \\ Valerie Suslow \\ Lynda Oswald \\ Working Paper 9511 \\ http://www.nber.org/papers/w9511 \\ NATIONAL BUREAU OF ECONOMIC RESEARCH \\ 1050 Massachusetts Avenue \\ Cambridge, MA 02138 \\ February 2003
}

\begin{abstract}
Margaret Levenstein is Associate Professor of Economics, University of Massachusetts, Adjunct Associate Professor of Business Economics and Public Policy, University of Michigan, and Faculty Research Fellow, National Bureau of Economic Research. Valerie Suslow is Associate Professor of Business Economics and Public Policy, University of Michigan. Lynda Oswald is Professor of Business Law, University of Michigan. An earlier version of this paper "Private International Cartels and their Effect on Developing Countries" was written as a background paper for the World Bank's World Development Report 2001. We are grateful for comments from Simon J. Evenett and participants in seminars at Yale University and the University of Massachusetts. Our thanks to Julia DeBeers, Arjun Jayadev, Jessica Nowicki, Natalia Lukito, Kurt Rademacher, and Sukmi Sukmiwaty for excellent research assistance. Special thanks also go to Charlie Perkins of Pipe Logix for providing data and to Dennis McNamara for assistance with chemical industry classifications. The views expressed herein are those of the author and not necessarily those of the National Bureau of Economic Research.
\end{abstract}

(C)2003 by Margaret Levenstein, Valerie Suslow, and Lynda Oswald. All rights reserved. Short sections of text not to exceed two paragraphs, may be quoted without explicit permission provided that full credit including Cnotice, is given to the source. 
International Price-Fixing Cartels and Developing Countries:

A Discussion of Effects and Policy Remedies

Margaret Levenstein, Valerie Suslow, and Lynda Oswald

NBER Working Paper No. 9511

February 2003

JEL No. L4, F1, O1

\section{$\underline{\text { ABSTRACT }}$}

We examine the possible effects of private international cartels on developing countries by looking in detail at three recent cartel cases, as well as at a broader cross-section of 42 recently prosecuted international cartels. We discuss the indirect effects on developing country producers, either as competitors or co-conspirators, as well the direct effects of cartels on developing country consumers. By combining trade data with a sample of US and European prosecutions of international cartels in the 1990s, we are able to estimate the order of magnitude of the consequences of these cartels on developing countries as consumers. In 1997, the latest year for which we have trade data, developing countries imported $\$ 54.7$ billion of goods from a sub-sample of 19 industries that contained a price-fixing conspiracy during the $1990 \mathrm{~s}$. These imports represented $5.2 \%$ of total imports and $1.2 \%$ of GDP in developing countries.

Margaret Levenstein

University of Michigan Business School

Ann Arbor, MI 48109-1234

and NBER

maggiel@umich.edu

Lynda Oswald

University of Michigan Business School

Ann Arbor, MI 48109-1234

ljoswald@umich.edu
Valerie Suslow

University of Michigan Business School

Ann Arbor, MI 48109-1234

suslow@umich.edu 


\section{Introduction}

The U.S. Department of Justice, the European Commission, and the Organization for Economic Cooperation and Development have all recently voiced concern about, and in the former two cases, increased their prosecution of, international cartels. These recent prosecutions of international cartels in a wide range of industries demonstrate that cartels have pernicious effects on consumers despite the obstacles created by legal prohibitions on collusion and individual firm's incentives to compete rather than collude.

As with private international cartels through history, most of the cartels recently caught in the antitrust net of the U.S. or EU competition authorities are made up of producers in industrialized, OECD countries. Therefore, it is not surprising that most prior studies of the impact of these cartels focused on the better-documented effects on wealthy, industrialized countries. ${ }^{1}$ This appears to be true of both business and public policy players, as there has been little activity on the part of developing country governments or developing country consumers to respond to these cartels even after they have been shown to exist. This contrasts with the actions of the Canadian government, which has consistently pursued anti-competition cases against firms who have been investigated first by either the U.S. Department of Justice or the European Commission. One exception to this generalization is Mexico, which took action against the lysine cartel, and is investigating the vitamins cartel. ${ }^{2}$ The lack of action in response to these cartels also appears to hold true of private parties in developing countries, which have, with only a few exceptions, apparently not actively sought civil remedies against cartel participants to the extent that consumers in western, industrialized countries have. There are a variety of reasons - legal, political, and economic -- why this may be the case. But, as this paper demonstrates, a lack of impact on developing countries is probably not one.

\footnotetext{
${ }^{1}$ Organisation for Economic Co-operation and Development, see Hard Core Cartels, 6 (Paris, France 2000). See also speech by Mr. Mario Monti, Member of the European Commission in charge of Competition, Fighting Cartels: Why and How? Why should we be concerned with cartels and collusive behavior?, Address at the Third Nordic Competition Policy Conference (Stockholm, September 11, 2000) and the U.S. DePARTMENT OF Justice International COMPETITION POlicy Advisory COMmitTeE, FinAl Report (U.S. GPO Washington, DC 2000).

${ }^{2}$ Brazil is also contemplating action against the lysine cartel. See Scott Kilman, European Commission Sets ADM Fine, WALL ST. J., June 8, 2000, at A4.
} 
This, in turn, suggests that a more comprehensive approach to promoting competition may be necessary. Current regulatory institutions are neither international enough nor sufficiently focused on promoting competition rather than simply prohibiting particular anti-competitive techniques to assure that global markets will be competitive and open to new producers. There is currently no competition authority that considers it within their purview to assure that developing country producers have access to markets uninhibited by restraints from private agreements by established producers.

The extant research on the impact of cartels on developing countries focuses on commodity price stabilization schemes among developing country producers of primary products. In these studies, the analysis focuses on developing countries as producers and industrialized countries as consumers. In contrast, the cartels in our sample produce sophisticated manufactured goods or services; their members are largely international corporations based in industrialized countries. We examine two aspects of the impact of these cartels on developing countries. First, we look at developing countries as producers, either competitors to or collaborators with, these international cartels. In three case studies, we examine the creation of barriers to entry by cartels and their impact on developing country producers or potential producers. We also examine the methods that may be used to induce cooperation with the cartel by developing country producers. Second, we take a cross-section sample of all international cartels prosecuted by the U.S. and EU in the 1990s and ask how price-fixing conspiracies may have affected developing country consumers. This two-pronged approach gives a more complete picture of the varied direct and indirect effects of international cartels on developing countries.

Section II begins with a brief overview of basic cartel theory and outlines the possible effects of international cartel activity on developing country producers and consumers. Section III describes three recent cartels and their effects: the citric acid, graphite electrodes, and seamless steel tubes cartels. Section IV presents a cross-section sample of forty-two private international cartels from the 1990s and estimates the effect of these cartels on developing country trade. Section V discusses the legal issues posed by foreign plaintiffs seeking antitrust remedies in U.S. courts for the anticompetitive conduct of international cartels. Section VI presents conclusions and policy implications. 


\section{Cartels and Their Effects}

\section{A. Cartel Basics}

There are a wide variety of organizations that may reasonably be described as international cartels. The focus of this paper is explicit price-fixing or market division agreements, known in policy circles as "hard core" cartels, among private producers from multiple countries. These agreements are illegal in the U.S. and the European Union. They have been the focus of increased prosecution by U.S. and European Union competition policy authorities over the last decade. (They are illegal in many other countries as well, although laws and enforcement vary.) There are other types of cartels, such as purely domestic cartels, private export cartels, and staterun cartels. Our analysis is limited to private hard-core international cartels. ${ }^{3}$

Producers form a cartel with the goal of limiting competition. By restricting output and increasing price, ideally to the price a monopolist would set (if the cartel controls the entire market), profits will be jointly maximized. Assume for the moment that the firms in an industry have overcome the coordination problems necessary to establish a cartel. Upon its creation a cartel immediately faces the problem of how to escape from the Prisoner's Dilemma: by raising price above marginal cost, the cartel creates an incentive for each producer to cheat. ${ }^{4}$ Each firm has an incentive to shave its price, increase its output and market share, and thereby increase its profits. But if each firm did so, collusion would immediately dissolve into competition. Repeated interaction (over time or across markets) can, by providing the incentive of future collusive profits, deter firms from cheating in the present and allow them to escape this Prisoner's Dilemma. This tradeoff can be expressed very generally as requiring that the

\footnotetext{
${ }^{3}$ Cartels with significant state involvement, such as OPEC, can certainly have important economic effects. Their goals, however, are much more complex than private cartels, including not only the maximization of joint profits, but economic stability and international political influence as well. The economic models that we use here, which presume a simple profit-maximizing objective function, are inadequate to address the functioning and impact of this set of international cartels. Thus, we have chosen to exclude them from our analysis.

${ }^{4}$ The classic presentation of firms' incentive to cheat on collusive agreements is George J. Stigler, $A$ Theory of Oligopoly, 72 J. POLIT. ECON. 44 (1964). For further discussion of cartel economics and a survey of empirical research on cartel stability, see Margaret Levenstein and Valerie Suslow, What Determines Cartel Success?, University of Michigan Business School Working Paper, 02-001 (January 2002).
} 
discounted expected stream of profits from future collusion exceed the profits earned by cheating today:

$$
\mathrm{E}\left[\Pi_{\text {cheating today }}\right]+\mathrm{E}\left[\Sigma\left(\Pi_{\text {following an incident of cheating }}\right)^{\delta}\right]<\mathrm{E}\left[\Sigma\left(\Pi_{\text {colluding forever }}\right)^{\delta}\right]
$$

This means that the likelihood that an industry will bother to exert the effort to establish a cartel will depend on several very basic factors that determine the expected profits associated with colluding. These include the benefits of colluding, the benefits of cheating, the extent of repeated interaction, and the discount rate.

Consider first the benefits of colluding. The incentive to create a cartel depends fundamentally on the cartel members' assessment of the potential for an increase in price to lead to an increase in profits. This depends, in turn, on such factors as the price elasticity of demand (as demand is more elastic, the potential for increasing profits decreases and the incentive to create a cartel decreases); the rate at which future profits are discounted (as cartel members become more impatient, collusion is harder to sustain); and variance in demand (at a minimum, demand fluctuations create coordination and complexity problems, as the optimal price changes whenever demand shifts).

Next, consider the benefits of cheating. If the benefits to cheating are sufficiently low relative to the gains from colluding, the industry will find that it lies within the bounds in which collusion is possible. In order to successfully collude, it will also be necessary for cartel members to devise punishment mechanisms that provide necessary further deterrence to cheating. That is, the second term on the left side of the inequality above (profits earned following an incident of cheating), must be very low or even negative. The extent of multi-market contact -- the number of times and places that two firms interact - is one determinant of the number of opportunities to punish cheating; as it increases, so does likelihood that collusion will succeed. Another important factor is industry structure on the buyer's side of the market. If consumption is concentrated in just a few customers, it is more likely that a cartel member would succeed in 
increasing its market share substantially with a small cut in price and therefore be more tempted to cheat. ${ }^{5}$

The ability of the cartel to punish cheaters also affects the benefits of cheating. Antitrust enforcement can make it difficult for a cartel to punish its members, particularly via a price war, as such punishment would make its existence more obvious to the antitrust enforcement authorities. Antitrust enforcement also limits the use of fines as punishments; in permissive antitrust environments, cartels have frequently used mechanisms in which a firm that has sold over its quota or in some other way violated the agreement (e.g., sold below the agreed upon price or outside its assigned territory) simply compensates the other parties. These mechanisms leave a trail of evidence, however, that must be avoided if there is a possibility of prosecution.

Following Stigler (1964), as developed by Green and Porter (1984), economists have focused on the importance of the observability of cheating to collusive stability. When cheating cannot be observed, it is harder to give firms an incentive not to cheat. It is more likely that collusion will be disrupted either by cheating or by events that are empirically indistinguishable from cheating. For this reason, firms in the cartel may find it useful to invest in information collection in order to support the collusive equilibrium. ${ }^{6}$ In addition, cartel members often find that there is no substitute for frequent face-to-face meetings, in order to compare market information and discuss alleged occurrences of cheating.

Finally, having established sufficient incentives for existing industry participants to collude, the ultimate critical element to sustainable cartel profitability is the existence of barriers to entry.

\footnotetext{
${ }^{5}$ On the other hand, our sample of recent prosecutions of international cartels suggests that successful collusion is possible in industries with large customers. The vitamins cartel, for example, lasted many years and sold to very large customers.

${ }^{6}$ David Genesove and Wallace P. Mullin, The Sugar Industry Learns to Organize Information Exchange, in LEARNING BY DoING IN FIRMS, MARKETS AND COUNTRIES 103 (Naomi Lamoreaux et al. eds., 1999) and Margaret Levenstein, Do Price Wars Facilitate Collusion? A Study of the Bromine Cartel Before World War I, 33 EXPLOR. ECON. HIST. 1107 (1996) examine the information collection procedures of two cartels in the sugar and bromine industries, respectively. Industry associations often engage in the collection and dissemination of information, which may facilitate collusion. The government may encourage this information dissemination, as the federal government did during the open price policies under the National Industrial Recovery Act, or as state governments did in the $19^{\text {th }}$ century salt industry. See Barbara Alexander, The Impact of the National Industrial Recovery Act on Cartel Formation and Maintenance Costs, 76 REV. ECON. STAT. 245 (1994) and Margaret Levenstein, Mass Production Conquers the Pool: Firm Organization and the Nature of Competition in the Nineteenth Century, $55 \mathrm{~J}$. ECON. HIST. 575 (1995).
} 
When firms do manage to coordinate their conduct on incentive-compatible collusive strategies, they create an incentive for outsiders to enter the industry. Coping with and preventing entry can undermine the best-laid collusive plans. In some industries it may be that firms resist the temptation to collude because they know that it would only lead to entry (which might, given any cost of exit, make the incumbent firms worse off).

The next section outlines the possible effects that an international cartel could have on either developing country consumers or producers. The price effects are clear enough. Therefore, we focus on the hidden entry barriers that may be created as a necessary part of the cartel.

\section{B. Potential Effects of Cartel Activity on Developing Countries}

For developing country consumers, or consumers in any country for that matter, the direct cost of a cartel is plain: price will increase if the cartel is successful. There may be other costs as well, such as decreased product choice (if the cartelized product is differentiated and geographic markets are allocated among producers) or a slower rate of technological change.

For developing country producers, again as with producers worldwide, there are both potential costs and benefits. Developing country producers may benefit from an industry price umbrella set by a U.S. or EU cartel, allowing non-cartel producers to sell at that price, or slightly below, without having to adhere to a cartel production quota. There are, however, potential negative effects as well, and developing country producers may be particularly susceptible to these effects. In order to ensure cartel survival, international cartels may engage in activity that blocks or slows entry by developing country producers. For example, cartel members may use tariff barriers and antidumping duties to prevent entry by developing country participants. International cartels may also use government-authorized, non-tariff barriers to prevent entry (e.g., quotas or regulation) or punish outsiders (e.g., using trade reporting and import surveillance by government agencies to track where other firms are selling). If these cartelimposed costs are significant, there will be a cost to the pace of economic development and the development process.

In addition to those barriers intentionally or inadvertently provided by national governments, cartels can also use private barriers to prevent entry. Historically, cartels have used a variety of 
different techniques to block entry. These include the threat of retaliatory or predatory price wars, use of a common sales or distribution agency (i.e., vertical foreclosure), and patent pooling. For the most part, the public record on recent price-fixing cartels does not discuss whether the cartel engaged in activities to block entry because such evidence is not necessary for a criminal conviction, at least in the United States where price fixing is per se illegal. In part, because of the secrecy surrounding cartel operations, we must rely largely on anecdotal evidence from which only tentative conclusions can be drawn. However, we have found descriptions of activities by contemporary international cartels that may have been attempts to deter or block entry by developing country producers.

One example is provided by the price-fixing conspiracy in the EU steel beam market between 1988 and 1994. Steel makers who were colluding to fix the price of steel beams "restrict[ed] the flow of information ... in order to freeze out any new competitors," according to Karl Van Miert, the EU competition commissioner. ${ }^{7}$ It is not clear from the published record what type of information steel producers were trying to restrict in the steel beam case, but we do know that in many industries information about technology and more formally, patent pools, have been used by cartels in the past to create barriers to entry. ${ }^{8}$

Or, consider the actions of graphite electrode producers from the U.S., EU, and Japan between 1992 and 1997 (discussed more fully below). The U.S. Department of Justice alleged that graphite electrode producers engaged in activity to disadvantage outsiders to their cartel, claiming that they "agreed to restrict non-conspirator companies' access to certain graphite electrode manufacturing technology." Again, while this charge appears in every individual indictment, indicating it was agreed upon by all cartel members, the details of the firms' actions are not given.

\footnotetext{
${ }^{7}$ Charles Goldsmith and Martin DuBois, European Commission Fines Steel Makers $\$ 116.7$ Million, WALL St. J. EUROPE, February 17, 1994, at 3.

${ }^{8}$ See, for example, Steven W. Usselman, Organizing a Market for Technological Innovation: Patent Pools and Patent Politics of American Railroads, 1860-1900, 19 BUS. AND ECON. HIST. 203 (1990), and Leonard S. Reich, Lighting the Path to Profit: GE's Control of the Electric Light Industry, 1892-1941, 66 Bus. HIST. Rev. 305 (Summer 1992).

${ }^{9}$ U.S. Dep't of Justice, Japanese Subsidiary Charged with International Conspiracy to Fix Prices for Graphite Electrodes in the U.S., Press Release, February 23, 1998.
} 
In another case, U.S. producers of ferrosilicon formed a cartel in 1989 and proceeded to use antidumping laws in the U.S. and Europe to bar entry to non-cartel members. ${ }^{10}$ However, the claim that firms were systematically filing anti-dumping claims and then withdrawing them following a, presumably threat-induced, agreement with importers has not stood up to rigorous empirical tests. $^{11}$

These kinds of activities may be particularly effective in limiting entry from developing country producers who are just entering international markets. If effective, developing country producers may be excluded. Even after cartels are broken up, the existence of these barriers may force developing country producers into joint ventures that limit their distribution or restrict it to certain markets. Such joint ventures could then function as a way for colluding firms to accommodate developing country entry into a cartel under their own terms or to engage in an implicit cooperative pricing arrangement. These arrangements give developing country producers access to the world market, but may do so at some cost to the degree of competition that would otherwise obtain in the industry. In several recent international cartel cases, joint ventures have been established in the years following the forced break-up of the cartel. This may reflect an attempt to consolidate and restructure the industry in a more direct way, in light of the break-up of the cartel.

Of course, both developing country entrants and established producers could also have other, welfare-enhancing motives for establishing such joint ventures, such as sharing technology, local market expertise, or capital. It is important to note that these explanations for joint ventures are not mutually exclusive; a joint venture might well accomplish both welfare-enhancing and competition-reducing goals of the participating firms. Joint ventures (and mergers) in industries known to have a history of international price-fixing should be scrutinized by regulatory authorities and structured so as to support the welfare-enhancing gains from cooperation while

\footnotetext{
${ }^{10}$ Richard J. Pierce, Jr., Antidumping Law as a Means of Facilitating Cartelization, 67 ANTITRUST L. J. 725 (2000).

${ }^{11}$ Using data from 1990 to 1997, Taylor (2001) finds that most withdrawn anti-dumping cases either have no effect on market price and quantity, or are followed by a decrease in price and increase in quantity. See Christopher T. Taylor, The Economic Effects of Withdrawn Antidumping Investigations: Is There Evidence of Collusive Settlements, U.S. Federal Trade Commission, Working paper 240 (August 2001).
} 
allowing consumers in both developing and industrialized countries the benefits of enhanced competition.

Given this overview of basic cartel operations and how cartel activity might affect developing countries, we now turn to three contemporary international cartel cases to find specific illustrations of these activities. In each case, we provide a brief overview of the industry and then discuss the price-fixing conspiracy and its possible effects.

\section{Three Illustrative Cartel Cases}

As we will discuss in Section IV, there have been approximately forty international cartels indicted and prosecuted in the 1990s by the U.S. Department of Justice and the European Union's European Commission. Of this sample, we have selected three cases to show the potential effects of international cartels on developing countries: citric acid, graphite electrodes, and seamless steel tubes. In these cases the effects of the cartel were felt worldwide and the cartel exported a significant percentage of the product to developing countries. Also, although the quality of the data varies, there is at least some price data obtainable in each case. There are other contemporary cartel cases where the cartel, although international in its membership, covered only a limited geographic scope (e.g., Western Europe). These cartels may have had significant effects for a period of time, but are not ideal for our focus on developing countries. In addition, there are other recent cartels in the sample that probably did have worldwide effects, but were either services or customized products, so adequate price and trade data are not available (e.g., cable-stayed bridges). In contrast, the three cases selected satisfy our criteria of having both broadly felt effects and publicly obtainable price data.

\section{A. Citric Acid Cartel \\ 1. Industry Background}

Citric acid is used primarily as a flavor enhancer and preservative, falling into a general category of chemicals called acidulants. Acidulants are naturally occurring acids that inhibit the growth of bacteria and can offset product sweetness with their tart flavor. In general, the main uses for citric acid are in soft drinks (its largest end use), processed food, detergents, and pharmaceuticals 
and cosmetics. The acidulant class also includes lactic, fumaric, malic and tartaric acids. Fumaric acid, for example, competes against citric acid as a preservative. It is generally cheaper, but has certain chemical characteristics (e.g., a stronger acid taste than citric acid), that make it an inferior substitute for many processed foods. ${ }^{12}$ Citric acid is the most widely used acidulant, accounting for about two-thirds of the total acidulant market.

Buyers can be large or small, but the large customers account for the bulk of citric acid sales. Given that the greater part of citric acid production goes to beverage companies, such as Coca Cola and Pepsi, the buyers are very large indeed. Procter \& Gamble is also one of the largest U.S. consumers of citric acid. In fact, in the United States, approximately 70 percent of citric acid and sodium citrate sales go to 10 to 15 end users. ${ }^{13}$

There are two primary production processes - shallow pan and deep tank fermentation. The deep tank process is preferred in most industrialized countries due to lower labor requirements and better quality control. This process does, however, require large amounts of energy as an input. ${ }^{14}$ Connor (1998) estimates the marginal cost of production at $\$ 0.60$ per pound during the conspiracy period. ${ }^{15}$ The shallow pan process is more labor intensive and less capital intensive, and therefore operates on a smaller scale.

Production is concentrated in the U.S., Europe, and China, although there are citric acid producers scattered throughout the world. In the late 1990s Western Europe, the U.S., and China together had an $88 \%$ market share of world capacity, estimated at approximately 1.2 billion pounds in 1994. Table 1 provides a summary of the key firms in the industry, their capacity, and market shares. The U.S. industry in 1990, just prior to the start of the conspiracy, had three players: ADM, Cargill, and Bayer AG (a German firm whose U.S. marketing was handled by Haarmann \& Reimer, its U.S. subsidiary). Cargill entered the industry in 1990, as the first

\footnotetext{
${ }^{12}$ Fumaric Acid, Chemical Marketing Reporter, July 24, 2000, at 33.

${ }^{13}$ Petition for the Imposition of Antidumping Duties: Citric Acid and Sodium Citrate from the People's Republic of China, filed by Akin, Gump, Strauss, Hauer, \& Feld, L.L.P. with the U.S. Int'1 Trade Comm'n, filed December 15, 1999, at 17. (Public version of document obtained from ITC website: http://dockets.usitc.gov.) Hereinafter referred to as "ITC Petition."

${ }^{14}$ ITC Petition at 15.

15 John M. Connor, What Can We Learn From the ADM Global Price Conspiracies?, Dept. of Agricultural Economics, Purdue University, Staff Paper \#98-14, August 1998, at 11. Hereinafter referred to as "Connor (1998)."
} 
producer vertically integrated forward from corn refining into citric acid production. All producers are now vertically integrated. In Europe in the early 1990s there were five producers in the citric acid market; the three largest were Bayer, Hoffmann-La Roche (a division of Switzerland's Roche Holding), and Jungbunzlauer International AG (Switzerland). These European companies, as well as smaller Chinese importing companies, satisfied most of the U.S. import demand during the mid-1990s.

Chinese producers have presented the most vigorous competition to U.S. and European manufacturers. Up to one hundred small firms entered the industry in the mid-1990s with the help of the Chinese government. Although the exact price differential has varied, in general Chinese citric acid sells in the U.S. for 10 to 20 cents less per pound than domestic supplies and European imports. Some consumers consider China's product to be lower quality and will not consider buying it, despite the price difference. For others, particularly industrial users, price is the major decision variable. Chinese exports peaked around 1994 and then dropped off as the Chinese government withdrew its subsidies and raw materials prices increased. Exports from China rebounded after the cartel was broken apart, suggesting that the effect of cartel barriers to entry on limiting Chinese production was greater than the incentive effect of a price umbrella. The Chinese producers as a group currently hold about $15 \%$ of the U.S. market share.

\section{Price-Fixing Conspiracy and Its Effects}

According to U.S. Department of Justice documents, firms in this industry fixed prices from approximately July 1991 to June $1995 .{ }^{16}$ Although the citric acid cartel did not control world production, it did account for $75-85 \%$ of sales in North America and Western Europe. ${ }^{17}$ Citric acid firms have been convicted for these activities in the United States, Canada, and the European Union. The fines are detailed in Table 2.

\footnotetext{
${ }^{16}$ U.S. Dep't of Justice, Justice Department's Ongoing Probe Into Food and Feed Additives Yields Second Largest Fine Ever, Press Release, January 29, 1997. The reported cartel dates vary somewhat, depending on the particular firm charged and the antitrust authority or private plaintiff bringing the suit. Connor (1998), for example, notes that DOJ indictments filed against the European participants in the conspiracy list July 1991 to December 1996 as the cartel dates. See Connor (1998), at 11.

${ }^{17}$ Connor (1998), at 13.
} 
There have been several follow-on suits by customers claiming damages. One civil suit filed by bottlers and food processors was settled in 1996 for a total of \$94 million (ADM, H\&R, HLR, and Jungbunzlauer were defendants). Cargill was named in this civil suit, but exonerated. In the court opinion of September 1, 1999 the judge wrote: "It is true that between 1990 and 1997 ADM, H\&R, and Cargill always changed list prices within a month of one another and generally did so in the same month...Although there appears to have been little competition in citric acid list prices, Cargill did price aggressively in actual contracts." This difference between list and transactions prices is important to keep in mind when we look later at the price trends in the industry in the past decade. In particular, large customers generally pay less than list price.

The members of the citric acid cartel fixed prices and allocated sales in the worldwide market, issued coordinated price announcements, and monitored one another's prices and sales volumes. ${ }^{18}$ In addition, the cartel members recognized the importance of policing and enforcing the agreement. They shared monthly sales figures and took stock at the end of the year of each company's total sales. A company selling more than its quota was required the next year to purchase citric acid from a cartel member that was under quota. ${ }^{19}$

The structure put in place by the citric acid cartel members was quite elaborate. The senior executives responsible for determining the broad outline of the cartel agreement were nicknamed "the masters." At first, when the cartel began in 1991, only the masters held meetings. Later, in 1993, "the sherpas" (lower-level executives) began to hold meetings as well in order to handle the day-to-day workings of the cartel and work out grievances between members. ${ }^{20}$

The U.S. price trend from 1990 through 1999 is shown Figure 1. Two price series from two different sources are plotted: Chemical Marketing Reporter (CMR) and Purchasing Magazine $(P M) .{ }^{21}$ One can see from the graph that the $C M R$ data is more representative of a list price, while the $P M$ data reflects, at least to some degree, true transactions prices. Prior to the

\footnotetext{
${ }^{18}$ U.S. Dep't of Justice, Justice Department's Ongoing Probe Into Food and Feed Additives Yields Second Largest Fine Ever, Press Release, January 29, 1997.

${ }^{19}$ Kurt Eichenwald, U.S. Wins A Round Against Cartel, New York Times, January 30, 1997, at 1.

${ }^{20}$ European Commission document DN: IP/01/1743. (05/12/2001)

${ }^{21}$ Most of these data (1987-97) are taken from Connor (1998) Appendix Table 1, which presents price data compiled from various issues of CMR and PM. We have updated the data series from the same two sources through 1999.
} 
conspiracy, during the time when the industry was adjusting to Cargill's entry and Pfizer's exit, there was a price war. Prices in early 1991 were driven down to the high-50 cent range. ${ }^{22}$ The price war ended in early 1991. List prices rose steadily after that, stabilizing at 85 cents per pound in the U.S. between 1993 and 1996 (this is reflected in the CMR line). According to Connor (1998), actual transactions prices, as reflected by the $P M$ line in Figure 1, stayed from 1 cent to 5 cents lower than list prices. For example, in 1991 CMR reported that "despite the 68cent list price, agreements are currently settled at about 63 cents." 23

Although the transaction price increase is slightly less dramatic, both price series in Figure 1 show a steady increase in price and then a decline after the conspiracy ended. EU Competition Commission Mario Monti reported that citric acid prices rose by 50 percent during the conspiracy. $^{24}$ One has to be careful, of course, about drawing strong conclusions from such statements or from the price charts included in this paper, since they do not control for other factors affecting price. For example, there are seasonal effects in pricing due to increased demand from the beverage market in late spring and early summer.

More generally, charges of increased cartel prices must be interpreted with care because some portion of the increase may reflect other factors such as rising raw materials costs or increases in demand. The price charts are purely descriptive, and do not purport to control for other relevant factors that may have affected prices during the conspiracy period. In addition, we do not estimate what the price would have been in the "but-for" world. That is, although it is clear that there was a conspiracy and that firms have admitted their guilt, we have not attempted to estimate the competitive price or the price that would have prevailed absent the cartel. Any conclusions, therefore, about the effects of cartel activity must be drawn with great care. ${ }^{25}$

In order to provide an estimate of the order of magnitude of the effect of this cartel on developing country consumers, we start with Connor's (1998) estimate that buyers in the U.S.

\footnotetext{
${ }^{22}$ Melissa Shon, Cargill, Jungbunzlauer Slate Citric Acid Additions, Chemical MARKeting Reporter, March 30, 1992, at 7.

${ }^{23}$ David Axinn, Citric Acid Marks Rise as Market Settles Down, Chemical Marketing Reporter, July 22, 1991, at 18.

${ }^{24}$ Competition: Monti Calls for Higher Fines on Cartels, EuROPEAn RePORT (September 13, 2000). Unfortunately, Monti does not specify whether he is referring to US or European price increases (or whether they were the same.

${ }^{25} \mathrm{We}$ are not able to estimate but-for prices due to lack of publicly available cost and transaction price data.
} 
paid an extra 21-24\% during the conspiracy, using marginal cost as the "but-for" or counterfactual price. $^{26}$ If we simply round down and assume that prices increased $20 \%$ on an approximately 300,000 million pound per year market in the "Rest of the World" (i.e., markets outside the United States, Canada, and Europe), so that the prices charged were ten cents per pound above the competitive level (which is substantially less than the observed price increase), this would amount to a cost of $\$ 30$ million per year to consumers. The cost to these consumers is also the benefit to cartel members. The monopoly profits earned in these markets provide an incentive for firms to collude; no corresponding punishment or fine has lessened this incentive.

It is possible that developing country producers may have received an increased price during the conspiracy period by riding on the coattails of the major producers. Conversely, developing country producers may have been damaged if the cartel was able to somehow prevent imports into its territory. The existing literature has reached no consensus on the net impact of these effects on cartel outsiders. We do have some evidence of attempts to limit entry from citric acid anti-dumping cases that were filed during the conspiracy period. India imposed anti-dumping duties on citric acid imports from China in November 1998. Before the duties were imposed, China had captured close to $40 \%$ of the Indian market for citric acid. If China was being excluded from the U.S. and European markets, either through anti-dumping cases or private restraints, they may have turned to India as an outlet for their product. Thus, this may not relate directly to the cartel, but could be an indirect consequence. It is even possible that the multinational firms that participated in the cartel were able to influence Indian policy toward Chinese imports. $^{27}$

\footnotetext{
${ }^{26}$ Connor (1998), at 10. Lawrence J. White, Lysine and Price Fixing: How Long? How Severe?, 18 REV. IND. ORGAN. 23 (2001). Lawrence J. White disputes Connor's use of marginal cost as the "but-for" price for the lysine conspiracy. White argues that the true "but-for" price was higher, based on the fact that the market was a four-firm oligopoly that probably would not have converged at an equilibrium price at marginal cost. White also argues for a shorter cartel period than Connor. Of course, from a policy perspective, the relevant question is what is necessary to achieve a competitive price that assures an efficient allocation of producers' resources and individual consumption decisions. Thus, for our purposes, the marginal cost price is the relevant comparison.

${ }^{27}$ There are other examples of attempts by international cartels to use anti-dumping laws to sustain collusion. The ferrosilicon price-fixing conspiracy lasted from 1989-1991 and involved producers from the U.S. and Norway. Five of the six major US manufacturers pleaded guilty and were fined. These same firms asked for, and received, antidumping duties that were placed on Brazil, China, and other countries. When the International Trade Commission found out about the U.S. firms' involvement in a cartel, it reversed the tariffs.
} 
U.S. producers have twice tried to use the government to help protect the domestic industry from Chinese imports. First, in 1995, while the cartel was still intact, producers lobbied the Office of the U.S. Trade Representative to include citric acid on the list of various Chinese imports to be hit with a high tariff. A last-minute agreement prevented the sanctions from being imposed. ${ }^{28}$ The second anti-dumping allegation was brought at the end of 1999 by ADM, Cargill, and Tate \& Lyle, who reacted to the rise in imports of citric acid from China by filing a petition with the Department of Commerce and the International Trade Commission seeking anti-dumping duties of $350 \%$ on Chinese imports. While U.S. prices in early 2000 averaged around 63-66 cents per pound, citric acid from China was selling for about 53 cents per pound. ${ }^{29}$ According to claims made in the case, the filing was prompted in part because two of the largest consumers of citric acid, Proctor \& Gamble and Ashland Chemical Inc. (a distributor) switched to Chinese citric acid for their raw material needs. Contradictory testimony was given regarding whether the quality of citric acid from China met U.S. standards. One Chinese supplier tried to qualify to supply Quaker Oats, for example, and was turned down (although this same supplier does sell to smaller U.S. food manufacturers). The ITC dismissed the case in February of 2000, after deciding that there was no material injury. ${ }^{30}$ At the hearings, it certainly weighed against the producers that these same producers had just been convicted and fined for cartel behavior. U.S. and European governments must be extremely wary of such attempts by firms to use the state as a tool for creating barriers to entry.

There has been rapid consolidation in the industry since the price-fixing conspiracy was revealed. Internationally, Hoffmann-La Roche completed its sixth joint-venture facility in China in 1997. Its partner, Wuxi Zhongya, is one of China's three largest producers. ${ }^{31}$ Cargill and Tate \& Lyle are both investing in Brazil, where a high quality and low cost sugar supply is attracting citric acid manufacturers. ${ }^{32}$ There are two ways to interpret these events. One is that, following the demise of the cartel, western producers are accepting entry from developing country

\footnotetext{
${ }^{28}$ Cheryl Cullinan Lewis, Citric Acid, PurChasing, May 4, 1995.

${ }^{29}$ Feliza Mirasol, DOC Investigates Possible Dumping of Citric Acid, ChEMICAL MARKETING RePORTER, January 17,2000 , at 4 .

${ }^{30}$ Clay Boswell, Pucker Up: A Taste for Tartness Drives Acidulants, Chemical Marketing Reporter, May 29, 2000 , at 16.

${ }^{31}$ Kevin Gopal, Keeping the Faith, PharmaceuticAl EXeCUTIVE, January 1, 1998, at 36.
} 
producers. The alternative is that former cartel members are attempting to re-establish market dominance, absent the cartel, through these joint ventures.

Prices have fallen, both in the U.S. and in Europe since the demise of the cartel. Figure 1 shows the general downward trend in U.S. prices since late 1995. CMR and PM both report that prices are down and stable, despite the fact that demand is strong. European prices, which tend to be lower than U.S. prices, have followed a similar pattern: the average price per kilogram ranged from $\$ 1.68$ - \$1.82 in 1995, \$1.04 - \$1.39 in 1997, and \$1.06 - \$1.17 in 1999 (still well above Connor's estimate of marginal cost). ${ }^{33}$

\section{B. Graphite Electrodes Cartel}

\section{Industry Background}

Graphite electrodes (GE) are large carbon columns used by electric arc furnaces (EAF) or "minimills" in the making of steel. These mini-mills use graphite electrodes to generate the enormous heat necessary to melt scrap metal and convert it back into a marketable steel product. GEs are made from synthetic graphite, for which the primary raw materials are petroleum coke, coal tar and petroleum pitch. The petroleum coke is crushed and mixed with the pitch into a paste, which is then extruded through a press. The electrodes are baked and undergo a series of refinements. The electrodes are then machined to meet the customer's specifications.

GEs are the only material that can generate sufficient heat to melt scrap steel. There is no competitive substitute, other than the more traditional methods of making steel (i.e., open hearth and basic oxygen). GEs make up about 6-7 percent of the cost of converting scrap to steel. Almost fifty percent of GE costs are raw materials costs, the bulk of which is petroleum coke (also called needle coke for electrodes applications). Labor costs represent about twenty percent

\footnotetext{
${ }^{32}$ Kiernan Gartlan, Tate \& Lyle To Expand Brazilian Citric Acid Operations, Dow Jones COMMODITIES SeRvicES, October 19, 2000.

${ }^{33}$ Citric Acid, European Chemical News, March 6-12, 2000.
} 
of total costs. ${ }^{34}$ The production process is highly electricity intensive, and therefore the electricity portion of the cost varies by location within a country and across countries.

A new plant takes 3-4 years to build. A civil complaint filed by numerous steel producers against the GE manufacturers highlights the significant barriers to entry that exist even without a cartel: "The production of GEs is a mature, capital-intensive business that requires detailed product and process know-how. It takes approximately four years to build a new plant with a 20,000-ton capacity. No significant new player has entered the industry since 1950." ${ }^{35}$ Thus entry is limited not only by high capital requirements but also by the importance of implicit technical and market knowledge.

There was a shakeout and consolidation in the industry in the late 1980s and early 1990s, just prior to the price-fixing conspiracy. The consolidation was precipitated by slumping steel production. In fact, GE industry capacity has shrunk by one-third since the mid-1980s. ${ }^{36}$ The number of producers has since stabilized. Table 3 provides a summary of the major firms in the industry and their market shares. In this highly concentrated market, UCAR International of the United States and SGL Carbon Corporation of Germany dominate, with a combined world market share of roughly two-thirds. Both firms manufacture electrodes in many countries (including such developing and transition economies as Brazil, Mexico, South Africa, Russia, and Poland) and sell throughout the world. There are also a number of other firms who are not global producers, but who do sell their product globally. The C/G Group, for example, has plants only in the United States, but sells throughout the world. Supporting this world market are fairly low transportation costs, generally less than $5 \%$ of the cost of the electrodes. ${ }^{37}$

\footnotetext{
${ }^{34}$ Barbara Martinez, Robert Krauss Chairman CEO and President of UCAR International, Dow JONES INVESTOR NETWORK, October 6, 1995.

${ }^{35}$ Ferromin International Trade Corp., et al. v. UCAR, et al. In the United States District Court for the Eastern District of Pennsylvania, Second amended complaint, filed May 1, 1999, at paragraph 47. Hereinafter referred to as the "Ferromin complaint."

${ }^{36}$ New Issues - UCAR International IPO, STANDARD \& POORS EMERGING AND SPECIAL SitUation Newsletter, November 14, 1994, at 15.

${ }^{37}$ Ferromin complaint, paragraph 50.
} 
The share of EAF production as a percentage of total world steel production has grown rapidly over the past two decades. Mini-mills now comprise about one-third of total steel production. Table 4 shows how EAF production was distributed around the globe in $2000:^{38}$

\section{Price-Fixing Conspiracy and Its Effects}

Price-fixing by graphite electrode producers began in 1992 and continued through at least $1997 .^{39}$ According to reports in the press, investigation of alleged price-fixing began after a complaint from a steel manufacturer. ${ }^{40}$ Lawsuits and criminal charges have been brought in the U.S., Canada, and the European Union. ${ }^{41}$ Convictions are detailed in Table 2. In the U.S., for example, there were seven firms indicted for price-fixing, UCAR, SGL, C/G, Showa Denko, Tokai, SEC, and Nippon, and six firms fined (C/G was granted leniency by the Department of Justice). An eighth firm, VAW Aluminum, was fined by the European Commission, but not by either the U.S. or Canada. Fines (not including civil damages) against these eight firms now total almost $\$ 500$ million.

After the GE firms pled guilty to the U.S. charges, dozens of civil suits followed. Almost forty U.S. steel producers sued for damages, and many of these suits have been settled. In general, although manufacturers in developing countries must have been damaged by many recent worldwide cartels, such as the vitamin, citric acid, lysine, and steel tube conspiracies, they have apparently not sued in U.S. courts. The graphite electrodes case is an exception, where a civil lawsuit has been brought by a group of non-U.S. steel producers. 27 international EAF steel producers, many of them from developing countries, filed the "Ferromin" antitrust suit in February 1999. ${ }^{42}$ The plaintiffs' firms reside in Turkey, Thailand, Australia, China, Australia, and Sweden. The defendants named are UCAR, SGL, Tokai, C/G, Nippon and SEC. The

\footnotetext{
${ }^{38}$ International Iron and Steel Institute, Trends and Indicators: World Steel Production Data, at http://www.worldsteel.org/trends_prod/prod06. (visited November 2000).

${ }^{39}$ EuropeAn UnION, Commission Fines Eight Companies in Graphite Electrode Cartel, European Union Press Release, July 18, 2001. As is the case in most such cases, the exact dates of the conspiracy are not known. The alleged dates of conspiracies vary depending on the claimant and the accused firm.

${ }^{40}$ Adam Jones, Blowing the Whistle - American-Style, THE TIMES, February 24, 2000.

${ }^{41}$ The Japanese Fair Trade Commission issued a warning to Japanese GE firms in March of 1998. There was no conviction or fine, apparently due to a lack of evidence.

${ }^{42}$ One of the plaintiffs is the Ferromin International Trade Corporation, which is a U.S. company that purchased graphite electrodes on behalf of its Turkish affiliates.
} 
plaintiffs claim that their purchases of GEs in the U.S., Europe, Australia and Asia totaled $\$ 180$ million over 1992-97 and that they were overcharged an average of 45 percent during this period. In June 2001 a U.S. District Court dismissed most of these claims giving standing only to those plaintiffs who state they can show that the GEs they purchased were invoiced in the United States. $^{43}$ We will discuss the legal issues arising from this case and a similar Christie's art auction case in more detail in Section V.

The information that we have on the cartel structure and organization comes almost exclusively from the U.S. Department of Justice's investigation. Cartel members agreed to: 1) increase and maintain prices, 2) eliminate price discounts, ${ }^{44}$ 3) allocate volume among conspirators, 4) divide the world market among themselves and designate the price leader in each region, 5) reduce or eliminate exports to members' home markets, 6) restrict capacity, 7) restrict non-conspirator companies' access to certain graphite electrode manufacturing technology, 8) exchange sales and customer information in order to monitor and enforce the cartel agreement, and 9) issue price announcements and price quotations in accordance with the agreement.

Each of the provisions listed above would be considered "normal" (necessary, but not sufficient) for the successful operation of a cartel. One of the most interesting aspects of the conspiracy is the agreement to restrict access to technology, although the Justice Department has, so far, provided no details of these allegations. One of the most noteworthy absences, though, is a provision of penalties for cheating on the agreement. This may have been implicit and discussed in the meetings, but never formalized. Since they did collect and share information on sales for the purposes of enforcing the agreement, there presumably would have been a discussion (or implicit threats) of the consequences of cheating.

The alleged price increases by the cartel were significant. In the United States, graphite electrode prices increased over 50\% from May 1992 through February 1997. The Ferromin antitrust claimants allege that the price increases they suffered averaged over $45 \%$. In Canada

\footnotetext{
${ }^{43}$ Ferromin complaint.

${ }^{44}$ More specific information on this point is given in Government's Sentencing Memorandum and Government's Motion for a Guidelines Downward Departure (U.S.S.G. §5K1.1), U.S. Department of Justice, Filed October 19, 1999. It says that all forms of discounts were to be eliminated, including rebates and consumption guarantees.
} 
prices rose by more than $90 \%$ over 1992-97. ${ }^{45}$ The Canadian market was much more concentrated at the time, consisting only of UCAR and SGL, with a combined market share during the conspiracy years of over 90 percent.

The U.S. price trend from 1980 through 2000 is shown Figure 2. The chart captures the fall in prices during the steel slump of the late 1980 s, a clear increasing trend in the nominal price of GEs during the cartel period, and a decline after the firms were convicted by the DOJ. (The dotted line indicates missing data for the mid-1980s.) Purchasing Magazine reports that the last price trough was \$2,100 per metric ton in early $1992 .{ }^{46}$ In May 1992 the U.S. price was \$3,123, and by February 1997 it had risen to $\$ 3,439 .^{47}$

Developing country producers may have been able to increase their prices under the rising cartel price umbrella. That does not mean that developing country producers would have charged the same cartel price; there may be quality differences or other differences in transportation costs, supply assurance, contract terms, and so on. Although this is a reasonable conjecture, given profit-maximizing behavior on the part of developing country producers, we have no data to corroborate this hypothesis.

Alternatively, developing country GE producers may have been damaged if the cartel was able to prevent imports into its territory. Indian graphite electrode producers have made exactly this accusation: "Producers claim that the electrodes are being dumped into India at a price of $\$ 2200$ per tonne as against the international price of $\$ 3200$ per tonne." 48 In response to a complaint filed by the Indian Graphite Electrode Manufacturers Association, the government imposed anti-

\footnotetext{
${ }^{45}$ Industry Canada, Competition Bureau, Foreign Corporation Fined \$12.5 Million for Price Fixing, News Release (July 18, 2000).

${ }^{46}$ Hotline, Purchasing, October 19, 1995. Viewed on the web at http://www.manufacturing.net/magazine/pu...ng/archives/z1995/pur1019.p5/102hots.htm.

47 There are a few details worth noting about the prices used for Figure 2. From 1992-97 they reflect prices in the United States, as laid out in the DOJ Sentencing Memorandum of October 19, 1999. Outside of that time period, prices are taken from a variety of sources, including Forbes, Oil and Gas Journal, Dow Jones Commodity Service, UCAR earnings reports, and C/G SEC filings. It is unclear whether the price quotes given before 1992 and after 1997 reflect world prices or U.S. prices. For example, one news source says "high-performance graphite electrodes are approaching $\$ 2,100$ per metric ton" without specifically stating whether this price applied to only the U.S. or more broadly.

${ }^{48}$ CVD on Graphite Electrodes Imports Likely, FINANCIAL EXPRESS, April 20, 1997, at 2.
} 
dumping duties in 1997 on imports from the U.S., several European countries, and China. ${ }^{49}$ Since the anti-dumping claims were filed in 1996, while the conspiracy was still operating, it is possible that the conspiring GE producers were trying to force the exit of, or at least discipline, Indian producers.

There has been a clear downward price trend since the conspiracy ended, as shown in Figure 2. This certainly reflects in part the Asian financial crisis that hit the steel industry and therefore the graphite electrode industry in late 1998. There is some evidence, albeit anecdotal, that points to readjustment to a new equilibrium in the industry since the cartel ended. One recent article mentions a "market share-driven price war" that has cut prices by five percent. ${ }^{50}$ In addition, individual companies have restructured in the face of mounting fines. Joint ventures are also being formed. In 1999, for example, UCAR entered into a production and marketing joint venture with Jilin Carbon, the largest Chinese producer of graphite electrodes. ${ }^{51}$ Whether such a joint venture facilitates or controls Chinese entry is not yet clear, but it does suggest that monitoring of industries by competition authorities after the breakup of a price-fixing conspiracy may be warranted.

\section{Seamless Steel Tubes (Oil Country Tubular Goods) Cartel \\ 1. Industry Background}

Seamless steel tubes, pipes, and casings are used in the construction of wells in the oil and gas industry. They are often referred to in the trade literature as Oil Country Tubular Goods (OCTG). Steel line pipes are used in the transmission of oil and gas from wells. Stainless steel tubes, made by established steel producers, represent new competition for the traditional OCTG product, and are the only substitute.

Demand is extremely variable over time. It is closely correlated with the amount of drilling currently being undertaken by oil and gas firms, which in turn depends on the price of oil and gas. This means that there is excess capacity in the steel tubes industry during periods of low oil

\footnotetext{
${ }^{49}$ Sharad Goel, HEG, Graphite Not Elated Over Dumping Duty on Electrodes, THE ECONOMIC TIMES, June 16, 1997.

${ }^{50}$ Purchasing Hotline, PURCHASING, June 1, 2000, at 3.
} 
prices. During periods of increasing oil prices, oil producers seem to accept price increases in OCTG, but OCTG prices also seem to come quickly down when the price of oil does, as steel producers try to make use of existing fixed capacity.

Natural gas creates greater demand for OCTG than does oil drilling, because natural gas wells are deeper. Thus, consumer substitution of natural gas for oil increases demand for OCTG (and the reverse). OCTG costs are not a large enough portion of the cost of production to lead to a shift between natural gas and oil in response to fluctuations in the price of OCTG.

Entry in to the industry is, in principle, fairly easy, and there are a large number of firms. The industry structure is, however, both more complicated and much more concentrated than a simple count of the number of firms would suggest (see Table 5). In the U.S., there are a small number of firms that produce a full line of steel tubes, casings, and line pipes, and sell that line to the industry. These firms are often vertically integrated steel producers. There are a large number of smaller firms that produce less than a full line of OCTG products. These firms are usually not vertically integrated and instead purchase semi-finished steel inputs. They often also purchase some OCTG or line pipe products from other manufacturers in order to offer a full line to their customers. These firms often customize (with specialized coatings, etc.) products for their customers. The U.S. firms sell primarily or exclusively to the North American market, which includes the Gulf of Mexico. Otherwise, U.S. firms do not seem active in the export of OCTG.

Other leading producers are located in Japan, Germany, France, Italy, Argentina, Mexico, Brazil, and Sweden. These producers sell to both U.S. and worldwide markets. Three large alliances, including all of the members of the former cartel, dominate world trade. The largest alliance is that of an Italian-Argentine firm (Techint), which controls OCTG producers in Mexico, Argentina, Italy, and Canada. These various relationships among steel tube producers, either as suppliers and customers, or as owners or partners in a joint venture, provide many opportunities for cooperation and may substantially lessen competition in the industry from what one would expect if these various industry participants were all independent competitors.

${ }^{51}$ John E. Sacco, UCAR Enters Joint Venture with Jilin Carbon, AMERICAN MeTAL MARKET, October 17, 2000. 
Internationally, the creation of alliances among major producers has also meant the consolidation of their sales forces. In fact, in the case of the alliance among Nippon, Kawasaki, and Sumitomo Metal it appears that the alliance is essentially the creation of a joint sales agency to distribute their goods worldwide. ${ }^{52}$ The opportunity to combine its sales force with the existing international sales network of Techint (DST) was apparently central to NKK's decision to spin off its OCTG unit to NKKTubes, which is now jointly owned by NKK and DST. ${ }^{53}$ While the use of a single, consolidated sales network may provide efficiencies in distribution or convenience for customers, it also make communication and coordination of prices and market shares much easier, and effectively prevents cheating by firms who have delegated sales to the joint distributor.

Smaller, independent oil and gas producers may rely on brokers while larger firms have in recent years been more likely to establish direct, long-term relationships with OCTG producers. For example, Pemex, the Mexican state-owned oil producer, entered into a long-term arrangement with Techint, whereby the Techint group provides just-in-time supplies of OCTG allowing Pemex to reduce its inventories to near zero.

This kind of relationship, which has grown more prominent since the demise of the cartel in 1995, has changed the structure of distribution in the industry. In doing so, it has increased the competitive advantages associated with vertical integration and horizontal size, because being large and diversified is necessary to being able to guarantee supplies to customers in an industry with such high variance in demand. It also has increased barriers to entry as customers are tied to long-term relationships.

\section{Price-Fixing Conspiracy and Its Effects}

It is unlikely that the cartel agreement had a direct impact on the U.S. market where prices are above world levels because of anti-dumping tariffs currently in effect. There has been no antitrust case to date in the United States. In December 1999, the European Commission fined

\footnotetext{
${ }^{52}$ Audrey McAvoy, Japanese Steel Companies Discussing Seamless Steel Pipe Tie-Up, Dow JonEs InTERNATIONAL News (August 18, 1999).

${ }^{53}$ NKK Merges Seamless Pipe Operations in JV with Grupo Techint, Dow Jones InTERNATIONAL News (November 2, 1999).
} 
four European and four Japanese steel manufacturers over $\$ 100$ million, charging them with fixing bids on seamless steel tubes and line pipes between 1990 and 1995. The European manufacturers included the inventor of steel tubes, Mannesmann; British Steel, now Corus, which exited the industry in 1994; Dalmine, indirectly owned at the time by the Italian government but privatized in 1996; Vallourec, a French steel producer who specializes in tubular products. The Japanese conspirators were NKK, Kawasaki, Nippon, and Sumitomo Metal. These eight independent firms created a cartel organization called the "Europe Japan Club." Under the auspices of the Europe Japan club they agreed "that the domestic markets of the different producers ... should be respected" so that producers refrained from selling in the home countries of the other members of the Club. ${ }^{54}$ In shared markets, the Club met regularly and designated which company was to win a particular job by bidding an agreed upon price, with the others to submit higher bids.

The European Commission decision covered restrictions on sales and pricing agreements in Europe. According to the EC, the cartel agreement also restricted competition in "certain third markets." The fines issued by the EC did not reflect these non-European markets because, the Commission concluded, there was no evidence that they had a restrictive effect on the European Union. Further details on this agreement have not been made public by the European Commission pending appeals by some of the accused. Because the EC has not included these other "third markets" in its decision, it is likely that details regarding this aspect of the agreement will never be made public. This points to an important weakness in international competition policy. The competition authorities in Europe may well have information regarding restrictions on competition in developing countries (or other developed countries), but under current law and agreements there is often not permission, let alone responsibility, to share that information with the affected parties.

We have detailed data for OCTG prices in the United States over the period in question. ${ }^{55}$ However, because of the substantial tariffs in place during this period, these may not be a good proxy for worldwide prices. Average prices of OCTG are presented in Figure 3. (Note that

\footnotetext{
${ }^{54}$ EUROPEAN COMMISSION, Commission fines cartel of seamless steel tube producers for market sharing, European Commission Press Release (December 8, 1999).

${ }^{55}$ We are extremely grateful to Charlie Perkins of Pipe Logix for providing us with this data.
} 
OCTG is produced in both electric resistance welded or ERW form and a seamless form. The cartel exerted control over both products, and Figure 3 shows both price series.) The OCTG price falls during most of the period of the conspiracy. However, this was also a period of low and declining oil and gas prices. Thus the observed prices, even in the U.S. where the cartel's effect was presumably only indirect, may have been higher than they would have been under competitive conditions. Further analysis, controlling for the price of oil and gas, is necessary to obtain a quantitative estimate of the effect of the cartel on prices.

Price trends in the industry continue to mirror oil and gas prices. U.S. prices fell during the early 1990s, reaching a trough in mid-1995. They then increased for three years until declines in oil prices in 1998 led to a $41 \%$ drop in U.S. OCTG demand and declining prices of OCTG. By the middle of 1999, OCTG prices were again increasing, as they continued to do for most of 2000.

The share of worldwide seamless tube exports coming from Germany, France, England, and Japan stayed roughly the same during the period of the cartel (Figure 4), actually increasing slightly toward the end of the period. As the cartel included the major producers from each of these countries, this measure is a reasonable estimate of cartel exports. To the extent that there were alliances between the cartel participants and producers in other countries, this measure actually understates the market share of the cartel. The fact that their market share does not decline suggests that entry (or expansion by non-participants) was not a viable source of increased competition during this period.

No evidence was found indicating that steel producers blocked entry or potential entry into the OCTG market from developing country steel producers. Several of the participants have production facilities in developing countries, including Brazil, Mexico, Argentina, and the transition economies of Eastern Europe. It appears that any sales of OCTG by producers from Eastern Europe will be accomplished through cooperation with one of these international alliances.

Since the demise of the cartel, the industry has undergone a fairly substantial reorganization, in which all parties to the cartel have joined in one of three international alliances. The largest of these, with a $25 \%$ market share of world consumption of OCTG is led by the Techint, an Italian- 
Argentinean firm controlled by the Rocca family. Techint controls Dalmine, the Italian member of the cartel, Tamsa, a Mexican tube producer, and Siderca, an Argentine steel producer. They are known jointly as the DST group. The Rocca family has been in the steel tube business since before World War II. Tamsa is currently under investigation by the Mexican Federal Competition Commission for taking advantage of its position as the sole seamless tube producer in Mexico. There is no indication in published reports that this investigation is linked to the European Commission charges. ${ }^{56}$ NKK, also a member of the Europe-Japan club, has now formed an alliance with DST, as has a Canadian producer.

As mentioned above, the other three Japanese producers who were members of the cartel (Nippon, Kawasaki, and Sumitomo Metal) have formed an alliance in which they use a single sales agency to represent all three. Mannesmann and Vallourec, the other two firms in the Europe-Japan Club have formed a joint venture to which they have transferred all their OCTG production. They are also engaged in steel tube joint ventures with Corus, another member of the Club that has exited the OCTG market.

China's exports of seamless steel tubes have increased significantly, but the current focus of its steel tube producers is improving manufacturing technology and product quality rather than expansion of capacity for export. ${ }^{57}$ This suggests that, at least in the short run, China will not significantly increase competition for established producers.

Tariffs continue to play a significant role in this industry and may well limit the entry of developing country firms not aligned with one of the three groups that dominate the industry. The European Union imposed anti-dumping duties on Ukraine and Croatia in February 2000. It has had anti-dumping tariffs in force against six other East European countries since 1997. Tariffs have been maintained in U.S. since 1995 against Mexico and since 1994 against Japan. ${ }^{58}$ The recently enacted steel tariffs specifically exclude OCTG from increased tariffs. ${ }^{59}$ Imports of

\footnotetext{
${ }^{56}$ Mexico: Investigation into Tamsa, Metal Bulletin, August 21, 2000, at 14.

${ }^{57}$ Chinese Steel Industry Will Mainly Develop Flat Products, ASIA PULSE (September 20, 2000).

58 Sumitomo Anticipates OCTG Rebound, AmERICAN METAL MARKET (April, 5, 2001).

${ }^{59}$ President of the United States of America, Steel Products Proclamation: To Facilitate Positive Adjustment to Competition From Imports of Certain Steel Products, (March 5, 2002) at http://www.whitehouse.gov/news/releases/2002/03/20020305-7.html.
} 
pipe into the United States have increased in part because tariffs on steel sheets have encouraged foreign producers to export finished products into the U.S.

\section{Summary}

There are a number of lessons to draw from these three cases. First, consider the potential for consumer welfare effects. International cartels can clearly have worldwide effects, but until now, no one has examined this issue directly. In certain cases these cartels significantly raised prices for several years. These price increases were on sophisticated intermediate goods, which are passed on to both consumers and downstream producers. It is particularly costly to the development process to raise prices and limit entry on this set of goods. Without prosecution by government authorities, consumers lack the information, resources, and, in some cases, legal structure to protect their own interests.

Second, the cases give us several insights into firm behavior and follow-on policy implications. One of the lessons is that access to technology and markets is actively limited by the cartels (or at least such attempts are made), using both governmental (tariff) barriers and private barriers. Governments must therefore be attentive to how they might inadvertently help to support cartel practices. In addition, significant industry restructuring often follows the break-up of cartels, yet no antitrust authority seems to be watching to see if competition is being preserved during the restructuring.

Also, we observe that some of these cartels came together during periods of increasing price competition, often following entry. In general, we suspect that cartel formation may also follow periods of market integration. Market integration alone, without vigorous anti-cartel enforcement, may give rise to increasing cartel activity rather than competition. Increasing liberalization of international trade may have inadvertently, by increasing competition in formerly protected national markets, increased the incentives for firms to participate in cartels. Such a response undermines the process of international integration, and decreases the benefits of economic integration to consumers around the world. It may also undermine political support 
for international liberalization if citizens believe that private barriers to trade will simply replace government-created ones. ${ }^{60}$

Finally, there is a regrettable lesson for empirical research. The effects of private (as opposed to state run) international cartels on developing countries are quite difficult to determine, even on a case-study basis. There is anecdotal evidence about prices and barriers to entry, but few definitive conclusions can be drawn. There are enormous difficulties in estimating the quantitative impact of cartels on developing country incomes because of the secrecy under which cartels operate, the lack of antitrust prosecutions in developing countries themselves (leading to a lack of information on the activities of cartels in developing country markets), and the general lack of data on individual transactions that might have been influenced by the existence of a cartel. For this reason, we turn to the trade data as a way to quantify, however roughly, the effects of contemporary international cartel activity on developing countries.

\section{Estimate of Developing Country Trade Affected By Recent International Cartels}

It is impossible to gauge the true number of international cartels in existence in the 1990s. However, we do know that the U.S. Department of Justice and the European Commission have recently successfully prosecuted at least forty-two different international price-fixing conspiracies that were in force at some point in the past decade. The surge in U.S. prosecutions of international cartels stems primarily from the revision and expansion of the Antitrust Division's corporate amnesty program in 1993. The number of corporations coming forward and seeking amnesty rose from roughly one corporation per year to one per month. ${ }^{61}$ On the heels of

\footnotetext{
${ }^{60} \mathrm{We}$ should note that some of the cartels in our cross-section sample, discussed in the next section, clearly pre-date recent moves toward international liberalization.

${ }^{61}$ Speech by Anne K. Bingaman, Assistant Attorney General, Antitrust Division, Opening Markets and Protecting Competition for America's Businesses and Consumers: Goals and Achievements of the Antitrust Division, U.S. Department of Justice, Fiscal Year 1993 through March 1996, March 27, 1996, at 8. See also Howard Adler Jr. and David J. Laing, The Explosion of International Criminal Antitrust Enforcement, BUS. CRIMES BULLETIN: COMPLIANCE AND LiTigation (March 1997). Adler and Laing state, for example, that "In 1991, only 1 percent of corporate defendants were foreign and no foreign individuals were charged that year. From July 1996 to January 1997, 20 percent of all corporations and 27 percent of all individuals charged were foreigners.” (p. 1)
} 
this increased enforcement by the U.S., both the European Union as well as some non-European countries have strengthened their anti-cartel laws and stepped up enforcement. ${ }^{62}$

From these recent international price-fixing cases, we have created a sample of forty-two international cartels on which the cross-section analysis in this paper is based (Table 6). We believe that this is close to the universe of international cartels that have been successfully prosecuted by the United States or the European Commission for fixing prices during the 1990s. Table 6 summarizes the dates of cartel operation, the legal entity (i.e., the U.S. or the EC) that prosecuted the case, the country of origin of the indicted firms, whether firms from developing countries are known to be participants in the price-fixing arrangement, and, finally, which country or countries are known to be affected (as consumers) by the cartel. In order to appear in this table, a cartel must satisfy the following five conditions: 1) it must involve more than one producer (otherwise, we consider it an extension of monopoly power case); 2) it must include firms from more than one country; 3 ) it must have attempted to set prices or allocate markets; 4) it must have existed during part or all of the 1990s (so, for example, there are cartels in our sample that began in the 1980s and ended in the 1990s); and, 5) it must have been successfully prosecuted by the U.S. or EU (or both). This sample, like its intellectual antecedents, may be biased as a result of its dependency on prosecution as a sample selection criterion. ${ }^{63}$

Table 7 shows reported market concentration figures and cartel price increase information for selected cartels. The typical international cartel has operated in a highly concentrated market (in those cases where we can find the information). Estimates of the increase in price resulting from these cartels vary widely by industry. At the low end, for example, we have a price increase of ten percent for the thermal fax paper cartel, which was formed as the industry was declining and lasted for less than a year. At the high end there is the price increase estimate of 100 percent for the stainless steel cartel, and 50-60 percent in the U.S. and 90 percent in Canada for the graphite electrodes cartel.

\footnotetext{
${ }^{62}$ See, for example, Michael Reynolds, EU Briefings, 18 InT'L FinANCIAL L. REV. 48 (1999). The article announces the decision within the European Commission to create a new unit to fight cartel activity.

${ }^{63}$ See Richard A. Posner, A Statistical Study of Antitrust Enforcement, 13 J. LAW ECON. 365 (1970); George A. Hay and Daniel Kelley, An Empirical Survey of Price Fixing Conspiracies, 17 J. LAW ECON. 13 (1974); Peter Asch and Joseph J. Seneca, Characteristics of Collusive Firms, 23 J. IND. ECON. 223 (1975).
} 
In order to determine whether developing countries were consumers of one of the cartelized products in the sample, we matched the products in Table 6 with import-export data for the sample period. The trade data come from Robert Feenstra's, World Trade Flows, 1980-1997, With Production And Tariff Data (Center for International Data, Institute of Governmental Affairs, University of California - Davis, 1999). The data include trade flows (imports and exports) for all countries, classified according to the Standard International Trade Classification (SITC), Revision 2. ${ }^{64}$ The data include only trade in goods. The list of developing countries is taken from the World Bank's World Development Report 2000/2001. ${ }^{65}$

Tables 8 through 13 summarize import data for thirty-two of the cartelized products in Table 6 for 1997, the most recent year for which trade data are available. ${ }^{66}$ The sample size falls from the forty-two to thirty-two for two reasons. First, the data on trade flows exclude services, so cartels that fixed prices on services were ruled out for further analysis. Second, goods were dropped from the sample where the data appeared to be misclassified or aggregated to such a level that no reasonable match to the cartel product could be made. Tables 8 through 10 contain a combination of less aggregated and more aggregated data. Whenever possible, the narrower, 4-digit SITC product code, was used to track the trade data, but if the data were missing for that category, we then used the broader, 3-digit code to categorize the cartel product. Tables 11 through 13 use less aggregated classifications (4-digit SITC codes only), and the number of products for which we can obtain data falls to nineteen. Even then, the SITC codes are, unfortunately, often broader than the product affected by cartel behavior. We indicate

\footnotetext{
${ }^{64}$ Countries that were formerly part of the Soviet Union are conspicuous by their absence from World Trade Flows. Thus, the data on imports, exports, and Gross Domestic Product presented here simply exclude those developing countries that were formerly a part of the Soviet Union. There are also cases where World Trade Flows grouped smaller countries together (especially smaller island countries). We do not believe that this leads to any substantial misclassification in the data presented here.

${ }^{65}$ According to the World Bank's classification, there are 155 developing countries, divided into three groups (lowincome, lower-middle-income, and upper-middle-income) and 52 "high income" countries. Examples of "lowincome" countries are Armenia, India, and Vietnam; examples of "lower-middle" are Albania, China, and Thailand; and, examples of "upper-middle" are Argentina, Czech Republic, and Turkey. Gross Domestic Product (GDP) figures are calculated from World Bank data (www.worldbank.org/data/countrydata/countrydata.html). The World Bank provides detailed data on its website with country-specific statistics. The figures for total GDP by country categories are based on the same set of countries as those in the World Trade Flows sample.

${ }^{66}$ These are the products for which we have been able to find minimally reliable data in international trade statistics. These data problems are discussed further below.
} 
discrepancies between the cartelized products and the SITC categories in the notes to Tables 8 13.

Tables 8 and 11 report 1997 imports of "cartel-affected" products as a percent of total imports to developing countries (using more and less aggregated product definitions, respectively) with countries aggregated by income categories. Tables 9 and 12 present 1997 import data for these same products, showing them as a percent of total GDP. Tables 10 and 13 give the total dollar value of cartel-affected imports. We also report in each of these tables, just for comparison, the analogous import values for high-income countries. In all of these tables we have deleted the cartels that dealt with services, but we have left in the names of each of the thirty-five cartel goods, so that it is easy to see where the missing data problems occur. For example, in Tables 810, we do not even have 3-digit data for explosives, nucleotides, or zinc phosphates (thus, the sample size falls to thirty-two). The number of products with missing data grows to sixteen in Tables 11-13, where we try to find 4-digit SITC category matches.

Although Tables 8-10 cover a larger sample size, the product definitions are often much too broad. We therefore focus on Tables 11-13. Examining the sub-sample of nineteen products those products that were cartelized at some point during the 1990s and for which we were able to obtain a good match to the trade data - the total value of such "cartel-affected" imports to developing countries was $\$ 54.7$ billion (see the last row in Table 13). This figure made up 5.2\% of all imports to developing countries in 1997 and equaled 1.2\% of their combined GDP. The impact appears to be largest on the most developed countries of the developing world. Cartelaffected imports made up 5.6\% of imports and 1.3\% of GDP for the "upper middle income" countries who have the income and industries that demand and rely on imports of sophisticated intermediate manufactured goods. While the total value of cartel-affected imports is higher for high-income countries (\$157.9 billion compared to $\$ 54.7$ billion), these imports represent a smaller proportion of imports and GDP (4.6\% and $0.9 \%$ respectively). Of course, in countries where producers belonged to the cartel, domestic production as well as imports is affected by cartel behavior.

Using more aggregated data, we can obtain data on trade for almost all industries in which firms have been convicted of fixing the price of goods (32 of 35 industries). This sample is more 
comprehensive, in that it includes all cartelized goods, but it is also less accurate, because the data include trade in many products that were presumably not affected by cartel behavior. Thus, these figures present an upper bound to the value of affected trade in these industries. This upper bound for the total value of affected trade is $\$ 155.9$ billion of developing country imports, representing $12.2 \%$ of their imports and $2.8 \%$ of their GDP (Tables $8-10$ ).

These numbers clearly do not represent an exact value of the imports to developing countries affected by all international cartels. The estimates are, on the one hand, biased downward because we include only some of the forty-two known price-fixing conspiracies. At the same time, even our lower estimate of affected trade, including only nineteen products, includes cases where the trade categories are broader than the products whose prices were fixed by the cartel. In general, when interpreting the trade data it must be kept in mind that some of the cartel product-SITC matches are poor. These estimates are intended to give a sense of the order of magnitude of affected trade, not an exact measure.

We can illustrate the typical problems with the data by using the citric acid, graphite electrodes, and seamless steel tubes cartels again as illustrative cases. We have not been able to obtain accurate international trade data for citric acid. Therefore, citric acid simply does not appear in Tables 11-13. As with other narrowly specified chemicals, we suspect that there is misclassification in the trade data, but whatever the source of the problem, volume of trade in citric acid is simply not available. Even if we did have import measures they would understate the full impact of the cartel on developing country consumers who pay higher prices not only for raw citric acid, but also for a wide range of citric-acid containing goods. We can, however, obtain data for the broader category of "carboxylic acids and their anhydrides and halides." This latter category is so broad that it contains at least five different products that have been affected by cartels. We use data on trade in "carboxylic acids and their anhydrides and halides" in Tables $8-10$, but there are surely other products in that category in which there is no cartel activity.

For graphite electrodes the situation is slightly better. Table 11 suggests that graphite electrodes constitute a significant fraction of developing country imports $(0.95 \%)$. Graphite electrodes are important to developing countries that manufacture steel using the EAF process, but the data that we present here undoubtedly vastly overstates their value, as this import category includes not 
only graphite electrodes, but all "otherwise unclassified electrical equipment." This broader category again includes more than one cartel product, as carbon cathode blocks also fall into this same catchall. On the other hand, if we did have a good match to graphite electrodes, that measure would understate the impact of the cartel on trade because the product is an intermediate good that is also imported into the developing country in a more processed state. To the extent that the graphite electrode cartel increased the price of steel imports to developing countries, focusing on graphite electrode imports understates the impact of the cartel. Therefore, the data must be read with a degree of skepticism.

The OCTG cartel-trade data match is also problematic. This category (seamless tubes and pipes; blanks for tubes and pipes) is much broader than the oil and gas goods that were included in this particular conspiracy. However, there have been recent European Commission decisions convicting an overlapping set of steel producers for fixing the price of steel heating pipes, steel beams, pre-insulated pipes, and stainless steel during the late-1980s to mid-1990s. ${ }^{67}$ Thus, it is possible that the prices of the other steel pipe products included in these import data have been affected by these various activities. Some imports included in these figures were certainly produced by firms who were not a party to these agreements. However, given the substantial market shares of the firms in the cartel, it is likely that their behavior changed the prices charged by firms who were not a party to and not even aware of the price fixing of their larger competitors. Without more information about the secret activities of cartels, it is impossible to determine the quantitative effect of these cartels on developing country incomes.

Even with these qualifications, it is clear from the magnitude of these figures that cartels have adversely affected a not insignificant portion of the trade, and therefore the trade balance, and consumption of developing countries. (Following the industrial organization literature, we focus on trade and consumption, though the impact on the trade balance is not an unimportant issue in a period in which some developing countries have experienced severe currency crises.) Given the actual and potential effects on trade that reach into the tens of billions of dollars, a natural

\footnotetext{
${ }^{67}$ Charles Goldsmith and Martin DuBois, European Commission Fines Steelmakers $\$ 116.7$ million, WALL ST. J. EuroPe, February 17, 1994, at 3; Emma Tucker, European Commission Ten Companies Penalised for Fixing Prices of Insulated Steel Heating Pipes, FinANCIAL Times, October 22, 1998, at 3: and Philip Burgert, EC Issues Fines for Stainless Price Fixing, AMERICAN Metal Market, January 26, 1998, at 2.
} 
question to ask is why these many affected countries are not seeking damages from cartel member firms in their home countries. In particular, given that the United States has the strongest laws and enforcement record against price-fixing, a legal mechanism for civil suits (which, the European Union, for example, does not have for antitrust violations), and some of the richest companies, why is it that there are relatively few lawsuits brought by foreign companies seeking damages? Not surprisingly, given the many recent international cartel prosecutions, there are a number of parties interested in this issue. The question of whether U.S. antitrust law can be applied to foreign transactions has recently become a lively legal issue, and it is one that we turn to now.

\section{Foreign Plaintiffs' Access to U.S. Courts in International Cartel Cases}

Consumers in developing countries harmed by the activities of international cartels may be unable to pursue legal remedies in their own countries, either because domestic antitrust laws prohibiting such behavior do not exist, do not provide adequate remedies, or are not enforced by the relevant authorities. In many such instances, those consumers may look to U.S. law instead for remedies for the antitrust injuries they have suffered. The ability of such plaintiffs to sue in U.S. courts is restricted, however, by the fact that U.S. antitrust laws do not reach all anticompetitive conduct. Rather, U.S. antitrust laws apply to "anticompetitive conduct directed at foreign markets that directly affects the competitiveness of domestic markets," but not to "anticompetitive conduct directed at foreign markets that only affects the competitiveness of foreign markets." ${ }^{168}$ In determining whether U.S. antitrust laws will apply to specific acts, the courts look to the effect of the anticompetitive conduct, not the situs of that conduct. ${ }^{69}$ This "effects" test can thus subject defendants whose anticompetitive conduct occurred solely outside the U.S. to suit in U.S. courts, where the effects of that conduct are felt in the United States.

Historically, U.S. courts have not been particularly sympathetic to the claims of foreign antitrust plaintiffs whose claims arise from anticompetitive conduct directed at foreign markets. However, a March 2002 decision of the U.S. Court of Appeals for the Second Circuit, Kruman v.

\footnotetext{
${ }^{68}$ Kruman v. Christie's International PLC, 2002 U.S. App. Lexis 3895 at*17 (2d Cir. Mar. 13, 2002).

${ }^{69}$ United States v. Aluminum Co. of America, 148 F.2d 416, $433-44$ (2d Cir. 1945).
} 
Christie's International $P L C{ }^{70}$ has suggested a broader mechanism by which foreign plaintiffs can pursue legal remedies in the U.S. courts for the anticompetitive behavior of international cartels.

The access of foreign antitrust plaintiffs to U.S. courts is largely governed by the Foreign Trade Antitrust Improvements Act (FTAIA) of 1982, ${ }^{71}$ which Congress enacted in an effort to clarify application of U.S. antitrust laws to foreign conduct and to limit application of U.S. antitrust laws when non-import foreign trade is involved. In particular, Section $6 \mathrm{a}$ of the FTAIA provides, in relevant part, that the Sherman Act "shall not apply to conduct involving trade or commerce ... with foreign nations unless . . . such conduct has a direct, substantial, and reasonably foreseeable effect . . . on trade or commerce which is not trade or commerce with foreign nations and such effect gives rise to a claim under" the Sherman Act. ${ }^{72}$

Until the Second Circuit's recent decision in Kruman, all of the federal courts which addressed this issue agreed that the FTAIA requires foreign plaintiffs suing under U.S. antitrust law to show: (1) that the alleged anticompetitive behavior had a "direct, substantial and reasonably foreseeable effect" on the U.S. marketplace and (2) that an anticompetitive effect on the U.S. marketplace gave rise to the plaintiff's claimed injuries. ${ }^{73}$ The coupling of these two requirements effectively bars many foreign plaintiffs from suing in U.S. courts for international cartel activities. To proceed, plaintiffs must be able to show that their injuries were caused specifically by the anticompetitive effect of the defendant's conduct on the U.S. marketplace and not by anticompetitive conduct that affects a worldwide market, even if that market includes the United States.

In Ferromin International Trade Corp. v. UCAR International, Inc. ${ }^{74}$ for example, 27 plaintiffs had alleged that they suffered injury as a result of price fixing and market allocation in the worldwide market for graphite electrodes between 1992 and 1997. The U.S district court

\footnotetext{
702002 U.S. App. Lexis 3895 (2d Cir. Mar. 13, 2002).

${ }^{71}$ Pub. L. No. 97-290, 96 Stat. 1246 (codified at 15 U.S.C. $\left.\$ 6 a\right)$.

7215 U.S.C. \$6a.

${ }^{73}$ See, e.g., Den Norske Stats Oljeselskap As v. HeereMac Vof., 241 F.3d 420 (5th Cir. 2001); Ferromin Int'1 Trade Corp. v. UCAR Int'l, Inc., 153 F. Supp.2d 700 (E.D. Pa. 2001); In re Copper Antitrust Litigation, 117 F. Supp. 2d 875, 876 (W.D. Wis. 2000); de Atudcha v. Commodity Exch., Inc., 608 F. Supp. 510 (S.D.N.Y. 1985).

${ }^{74} 153$ F. Supp.2d 700, discussed supra notes and accompanying text.
} 
dismissed the claims of 16 of the plaintiffs, stating that although the plaintiffs had alleged a number of anticompetitive effects upon the U.S. marketplace resulting from the defendants' conduct, the plaintiffs had not alleged that their injuries stemmed from the effect of the higher prices for graphite electrodes in the U.S. market (as opposed to higher prices in other, foreign markets). Indeed, the court found that the higher prices paid by those foreign plaintiffs were caused by anticompetitive effects in foreign countries, not in the U.S. The court allowed the claims of the remaining 11 plaintiffs to go forward, however, because some of the electrodes purchased by these plaintiffs were invoiced in the U.S., thus satisfying the "causal requirement" that these plaintiffs were injured as a result of higher prices in the U.S. marketplace. ${ }^{75}$

In its recent decision in Kruman, however, the Second Circuit deviated from prevailing precedent on the meaning of Section 6a of the FTAIA, opening the door to more suits by foreign plaintiffs. In a sense, the Kruman decision was a narrow one, as it was based specifically upon existing Second Circuit precedent, and thus its impact on the law of other circuits is uncertain. In another sense, however, the Kruman decision was of wide-ranging impact, both because of the prominence of the Second Circuit and because the decision created a circuit split on an issue of significant importance - the availability of U.S. antitrust remedies to foreign plaintiffs who were harmed by anticompetitive conduct directed at least in part to a foreign marketplace. The legal and policy implications of the Kruman decision are substantial and deserve careful exploration, as the issue may well end up before the U.S. Supreme Court for ultimate resolution. ${ }^{76}$

The Kruman court rejected the two-step test articulated by all other federal courts addressing this issue. Specifically, the court determined that the FTAIA had not altered prior law in the Second Circuit with respect to the nature of the effect that anticompetitive conduct directed at foreign markets must have on the domestic marketplace in order to be actionable under U.S. antitrust laws. Under the Second Circuit's National Bank of Canada rule, 77 "anticompetitive conduct directed at foreign markets is only regulated by the Sherman Act if it has the 'effect' of causing injury to domestic commerce by (1) reducing the competitiveness of a domestic market; or (2)

\footnotetext{
${ }^{75} \mathrm{Id}$. at 706 .

${ }^{76}$ A detailed analysis of the Kruman decision is outside the scope of this paper, but we plan on addressing this issue in future research.

${ }^{77}$ See National Bank of Canada v. Interbank Card Assoc., 666 F.2d 6, 8 (2d Cir. 1981).
} 
making possible anticompetitive conduct directed at domestic commerce. ${ }^{.78}$ The first prong of this test encompasses anticompetitive conduct that is directed toward both foreign and domestic markets and that actually reduces the competitiveness of the domestic market. The second prong encompasses anticompetitive conduct that is "directed only at a foreign market, but has the effect of allowing a separate course of conduct that directly affects the competitiveness of . . . domestic markets. ${ }^{, 79}$

The effect of the Second Circuit's rule is to allow antitrust suits to proceed in instances in which other federal courts would find the FTAIA prohibited such suits. The plaintiffs in Kruman were buyers and sellers at foreign auctions who alleged that they were overcharged for auction services in auctions held outside the U.S. as a result of a price-fixing conspiracy by the defendants. (A separate suit was brought by plaintiffs who alleged they had been overcharged for auction services in auctions held in the U.S. as a result of domestic price-fixing conspiracy by the same defendants.) Because the plaintiffs had alleged only that they had paid inflated prices at foreign auctions, the district court dismissed their claims, stating that they had not satisfied the FTAIA's requirements. While the imposition of high prices overseas may have had an effect ultimately on the U.S. marketplace, the plaintiffs had not alleged that this domestic effect gave rise to their injuries. ${ }^{80}$

The Second Circuit reversed, noting that the plaintiffs had alleged that the domestic price-fixing scheme could not have succeeded in the absence of the foreign price-fixing scheme. If this was true, the foreign conduct clearly had an anticompetitive effect upon the domestic market. The "conduct" at issue could be described as an agreement to fix prices in both foreign and domestic markets, which conduct clearly has an effect upon domestic markets because it includes conduct directed at a domestic market. Alternatively, the "conduct" could be "described as an agreement to fix prices in the foreign auction market that made possible an agreement to fix prices in the domestic auction market." ${ }^{\prime 11}$ In either event, one of the prongs of the National Bank of Canada rule is met, and the FTAIA would not bar the plaintiffs from bringing suit in a U.S. court.

\footnotetext{
${ }^{78}$ Kruman, 2002 U.S. App. Lexis 3895, at*5-*6.

${ }^{79} I d$. at $* 22$.

${ }^{80}$ Kruman v. Christie's Int'l PLC, 129 F. Supp.2d 620 (S.D. N.Y. 2001).

${ }^{81} 2002$ U.S. App. LEXIS 3895 at *40.
} 
Without ruling on the issue, the Second Circuit discussed the applicability of its ruling to international cartels. In identifying the type of conduct that would satisfy the first prong of its National Bank of Canada test (i.e., conduct that would have the effect of injuring domestic commerce by reducing the competitiveness of a domestic market), the court provided the example of an international cartel whose anticompetitive behavior was directed at both domestic and foreign markets, and stated that "the FTAIA was clearly intended to regulate such conduct." 82

The Kruman court did limit the scope of the conduct that could be regulated by U.S. antitrust laws. The defendants had argued that given the nature of the modern global economy, with its global marketplaces, any anticompetitive conduct that affects foreign markets could conceivably affect the U.S. economy and so lead to a suit under U.S. antitrust laws. The Kruman court rejected this line of reasoning, however, noting that under its test, such conduct would be actionable only if it caused injury to domestic commerce through an anticompetitive effect or by making possible anticompetitive acts directed at domestic commerce. In addition, the court noted that the FTAIA itself also limited the reach of the antitrust laws by requiring that the "effect" of the conduct be "direct, substantial, and reasonably foreseeable," 83 stating that this standard would prevent conduct with a merely "ancillary effect" upon U.S. markets from being actionable under U.S. antitrust laws.

At this point, we have many questions and few answers regarding the Second Circuit's ruling. There are significant jurisprudential and policy issues raised by this decision. On the legal side, for example, the Kruman ruling leaves open issues of proof (will they be insurmountable for the foreign plaintiffs?) and how to measure the remedies. On the policy side, questions about the costs and benefits of this decision, if it stands, are numerous. For instance, what does the U.S. have to gain by allowing such lawsuits to proceed? Is it primarily an additional instrument of deterrence against anticompetitive behavior? How can we gauge whether the benefits to the degree of market competition in the U.S. as a result of this rule with outweigh costs to the U.S. legal system? These questions highlight an important avenue for future research.

\footnotetext{
${ }^{82}$ Id. at $* 39$ n.9.

${ }^{83} 15$ U.S.C. $\S 6$ as (quoted id. at $* 42$ ).
} 


\section{Conclusion}

In this investigation of the effects of international cartels on developing countries we have addressed both developing countries as consumers, as well as developing countries as competitors or co-conspirators. The cases discussed show the potential for an international cartel made up of producers from industrialized countries to have simultaneously harmful effects on developing country consumers and harmful or beneficial effects on developing country producers.

The multi-dimensional role that U.S. and EU governments play in responding to these cartels has varied effects on developing countries. The vigorous prosecution of international cartels by the U.S. and EC may well open up entry possibilities to developing country producers. On the other hand, these governments are also susceptible to manipulation by domestic producers using tariff barriers and anti-dumping duties to protect the home market, either during or after the conspiracy. As raised in the previous section, impending legal decisions on whether to take a narrow or broad view of the application of U.S. antitrust law will have a direct effect on damages suffered by developing countries from international cartels.

Finally, there is the role of the antitrust authorities in holding confidential certain information that could clarify the effect of cartels on developing country consumers and producers. In general, although U.S. and EC decisions often mention that a cartel had effects "in the U.S. and elsewhere" or in "certain third markets," those effects are never included in calculating punishments. Details regarding the effects of the cartels outside of U.S. and EU markets will, in general, never be made public. This points to an important weakness in international competition policy as it affects developing countries. The competition authorities may well have information regarding restrictions on competition in developing countries, but under current law and agreements there is often not permission, let alone responsibility, to share that information with the affected parties. These and other issues will need to be addressed as international anticompetitive conduct collides with national competition policies. 


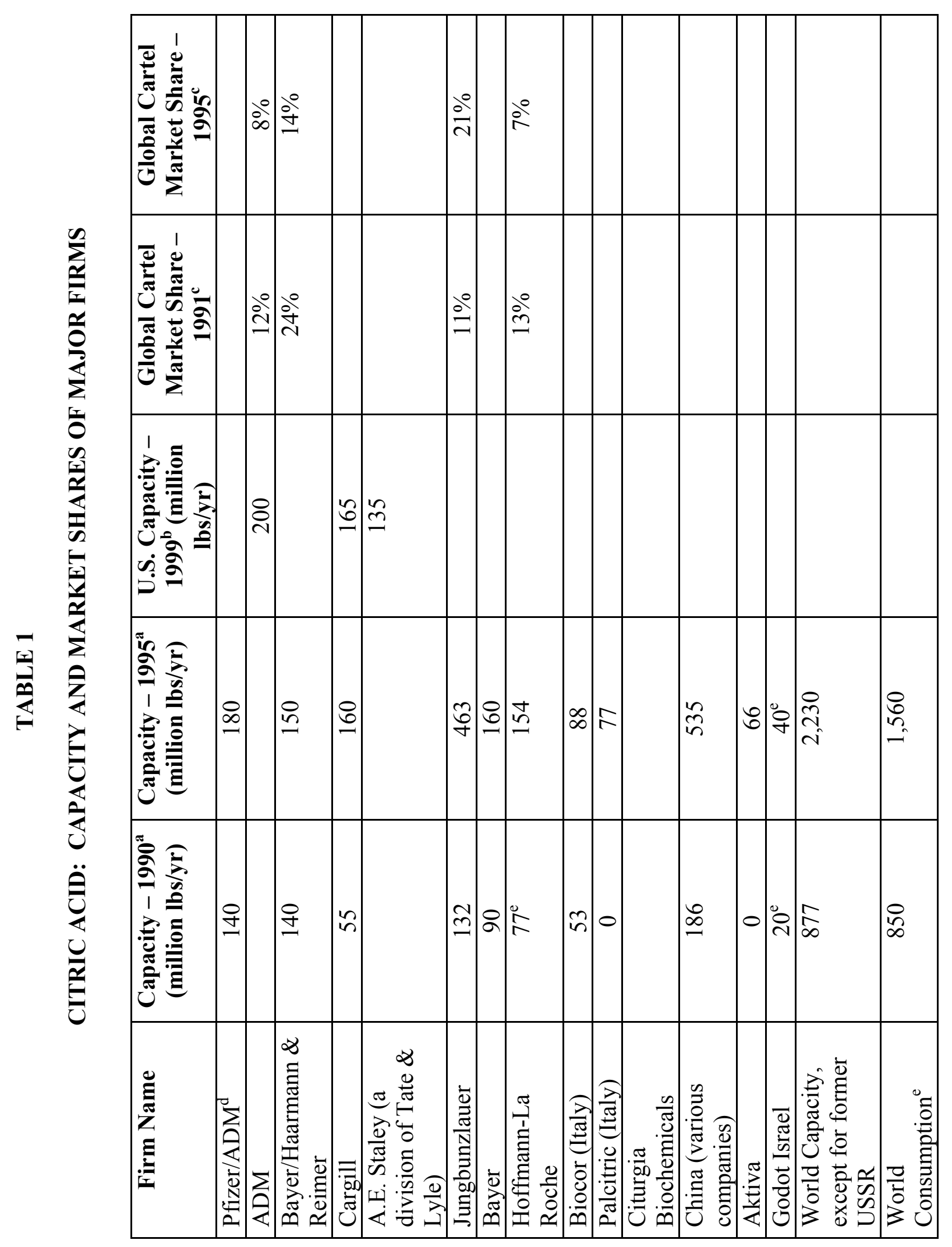



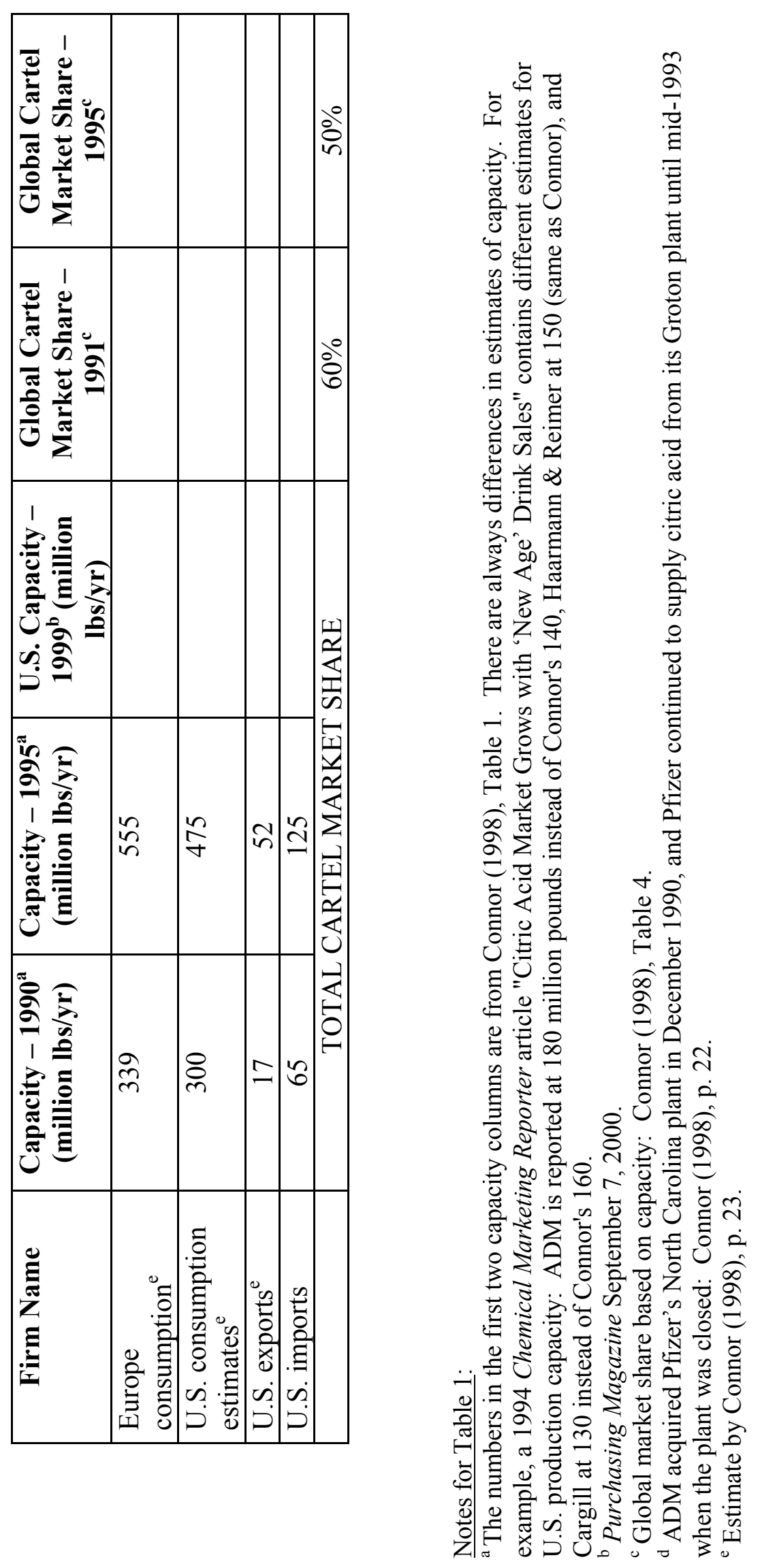


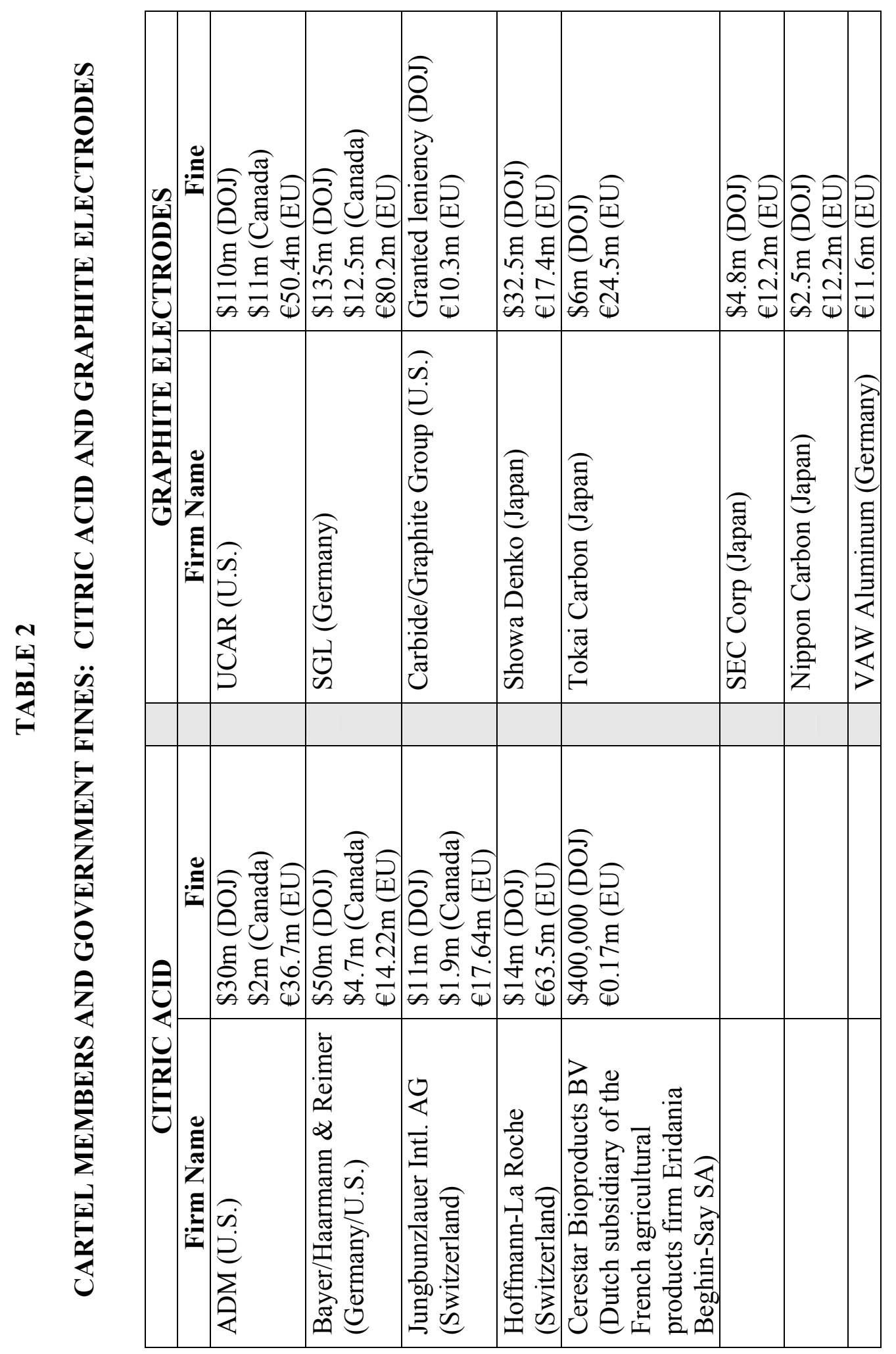




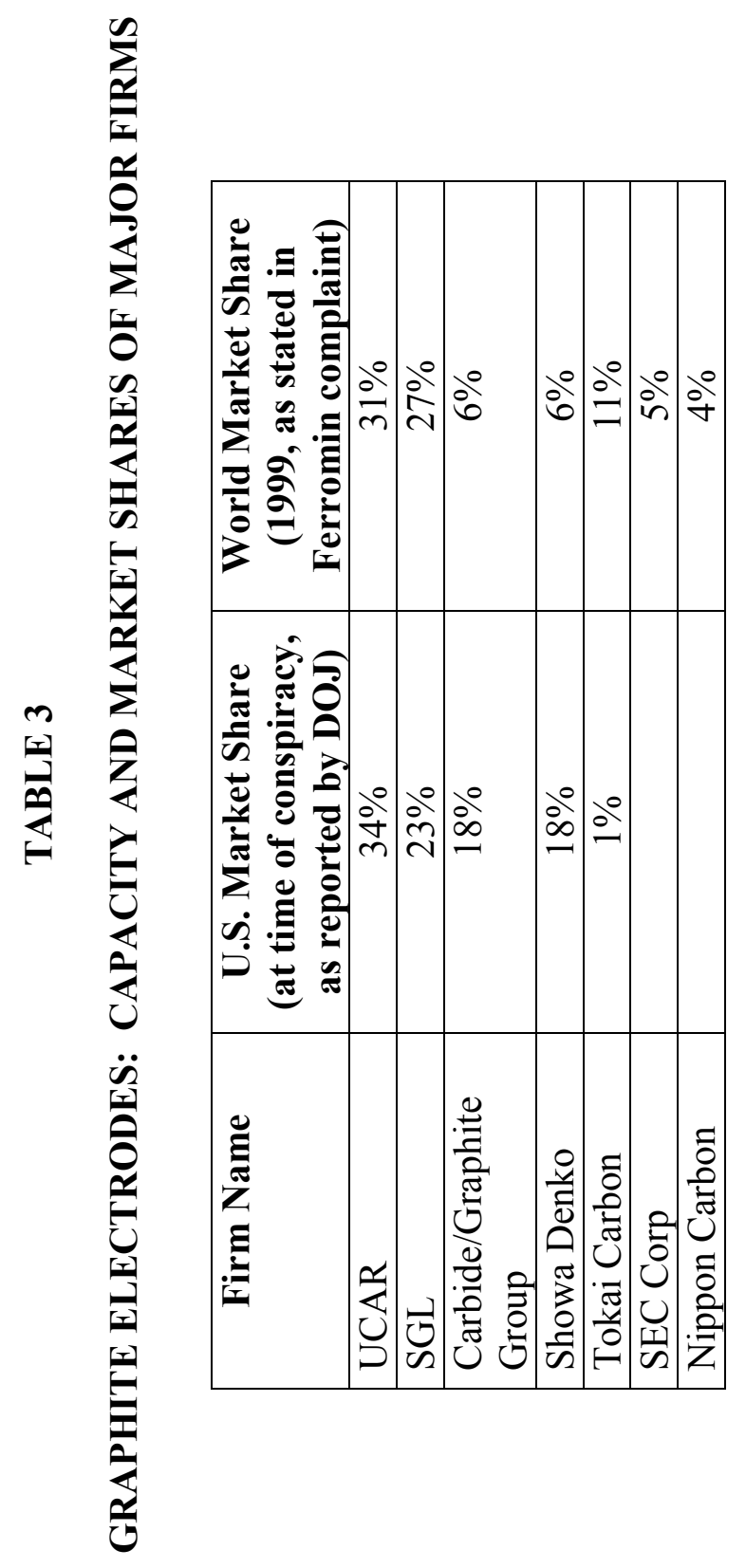

サ 


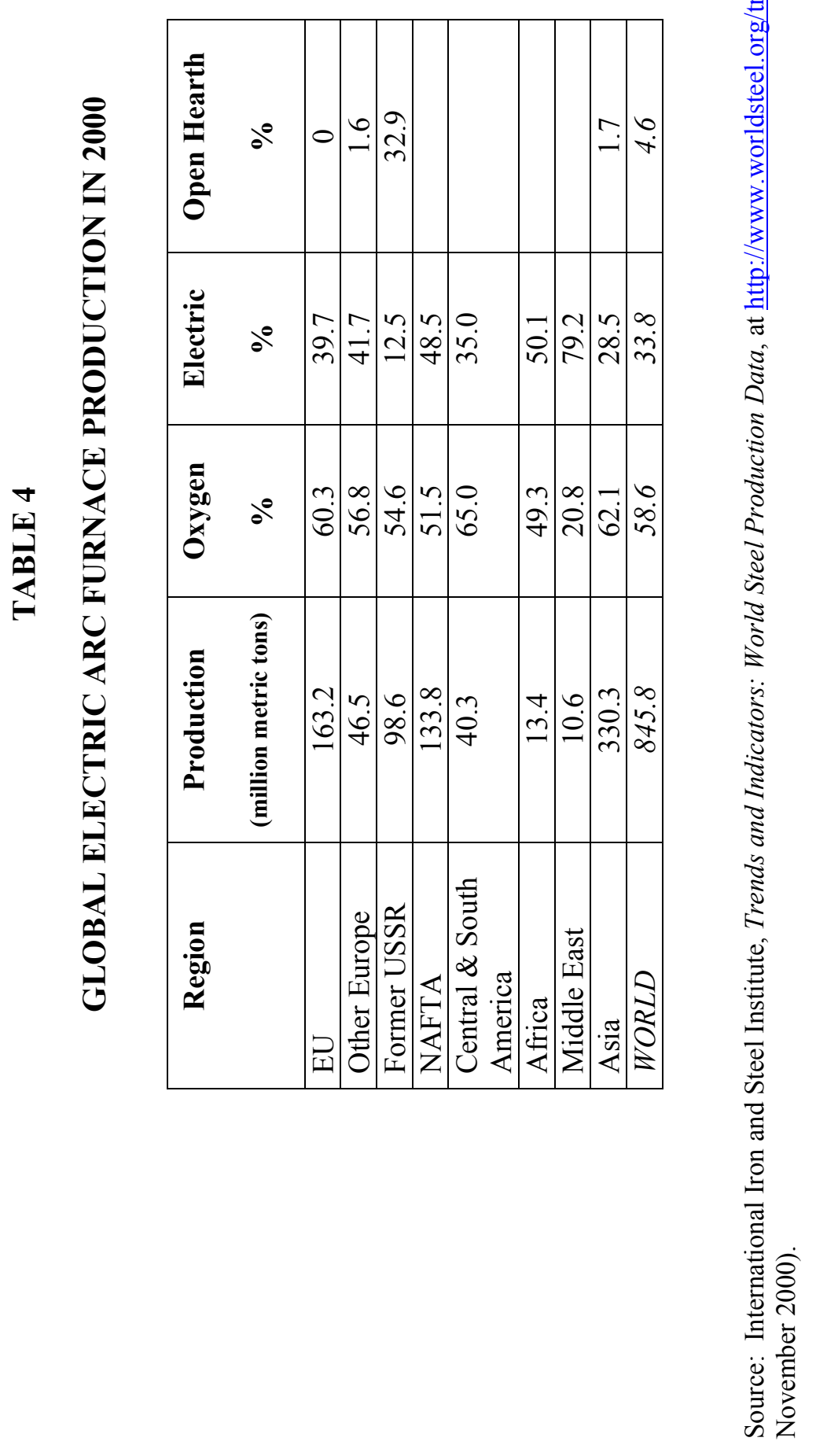




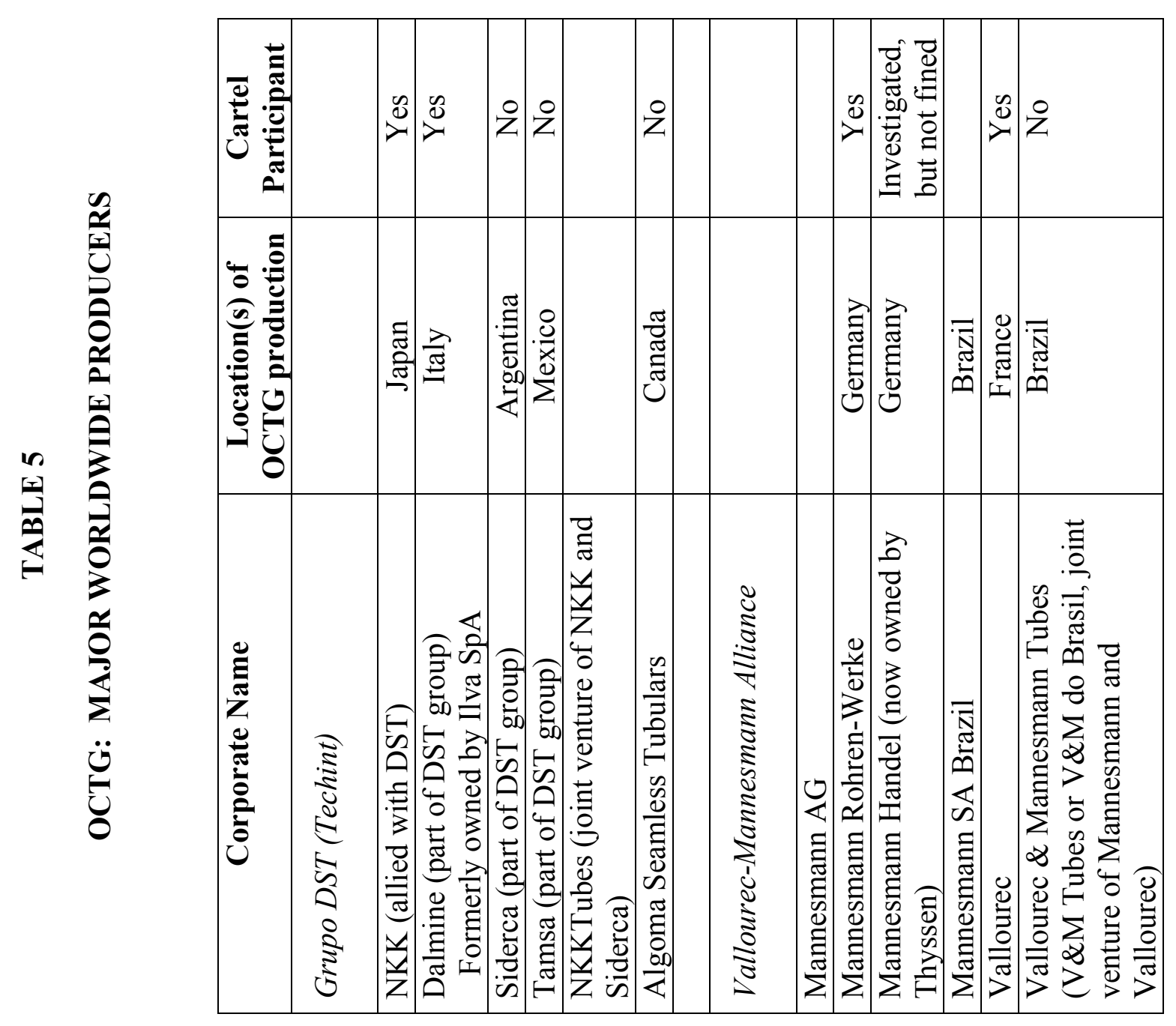




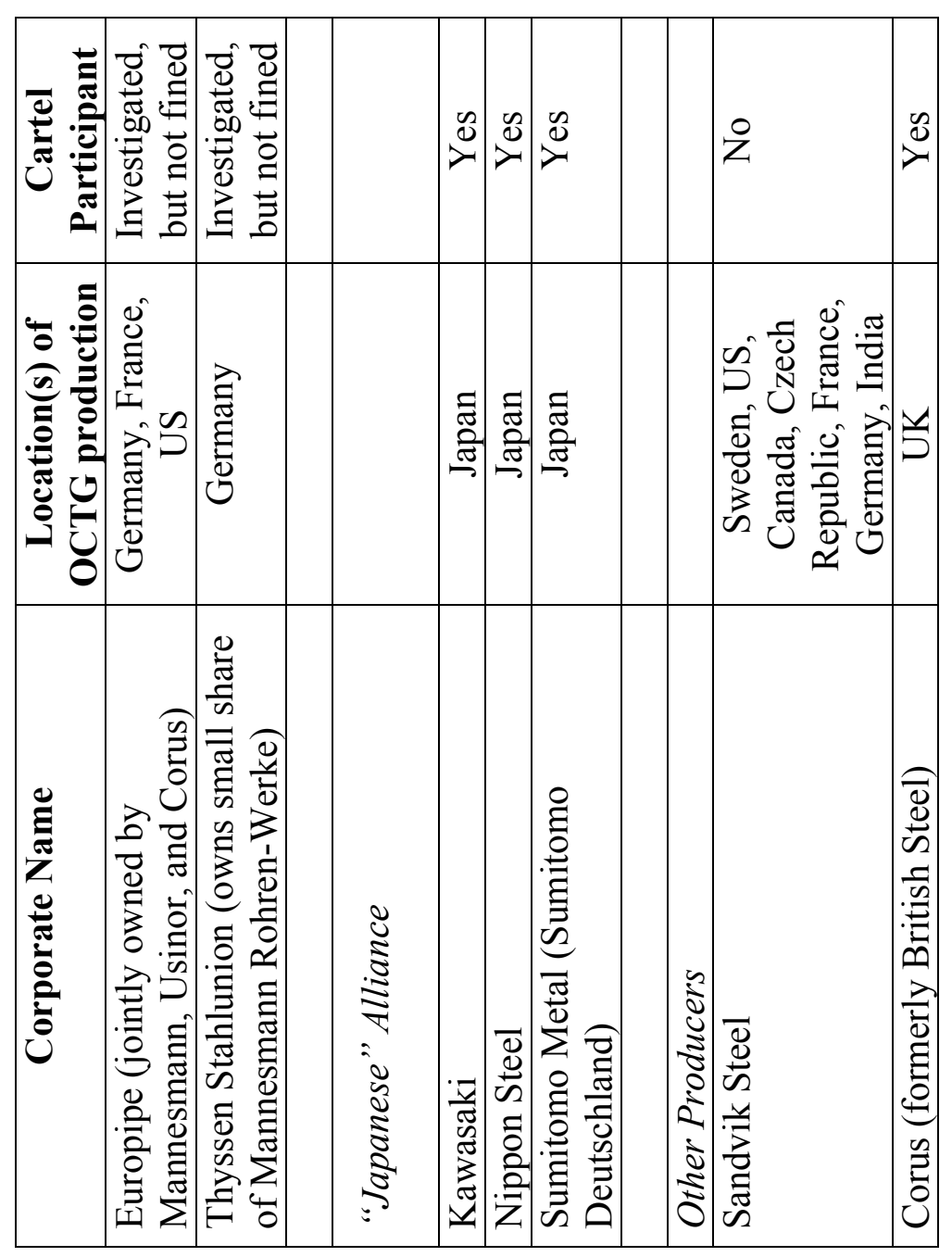




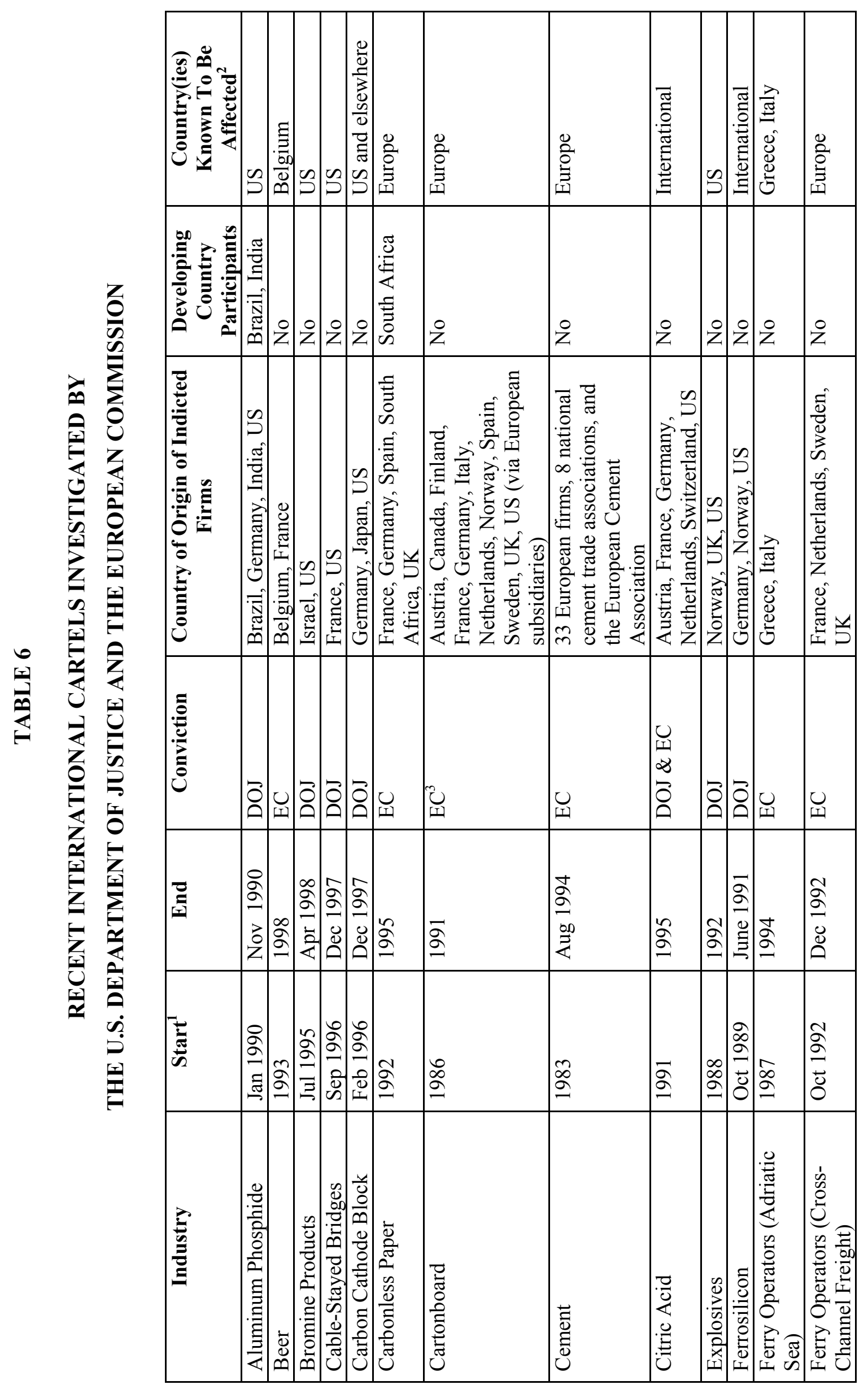




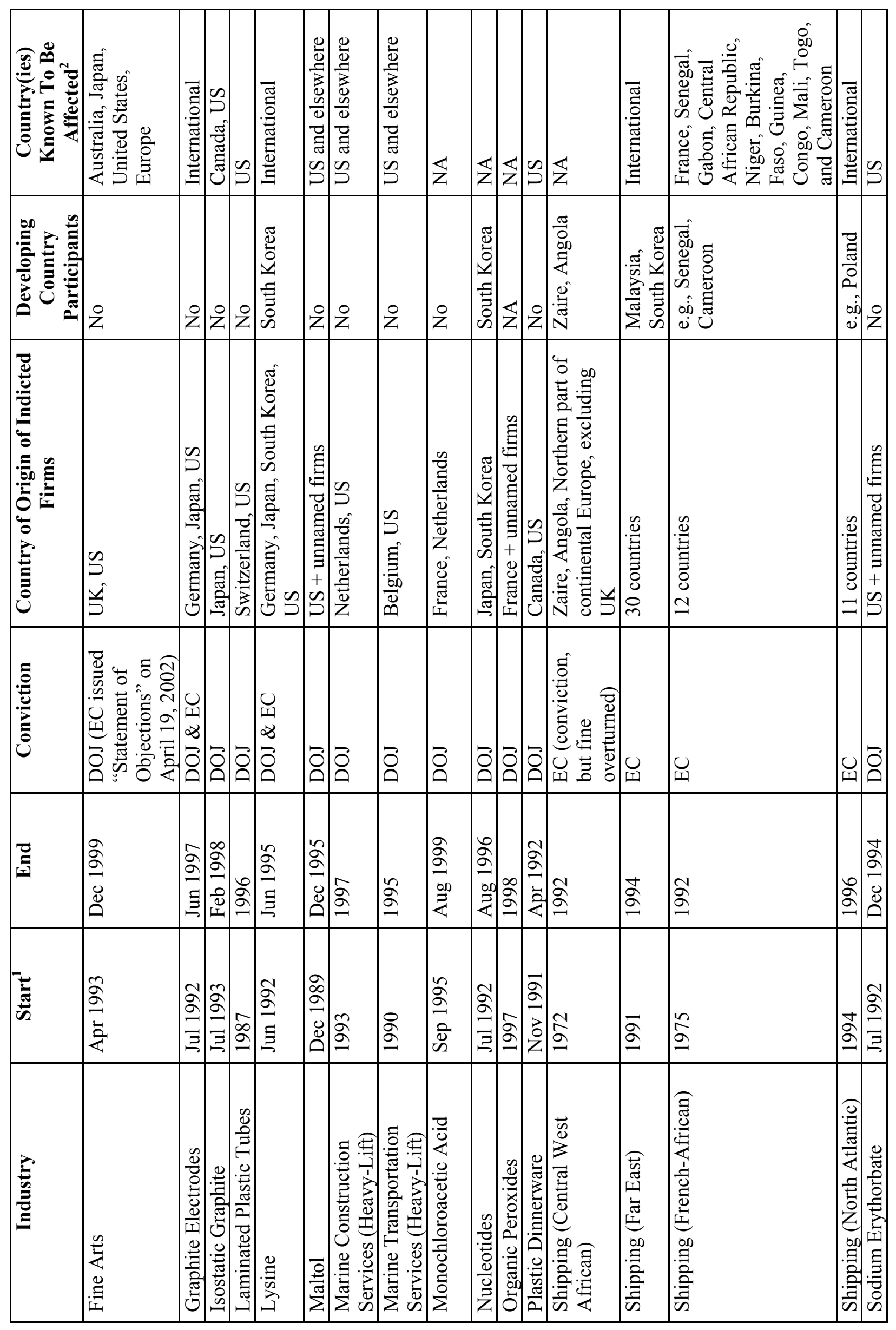




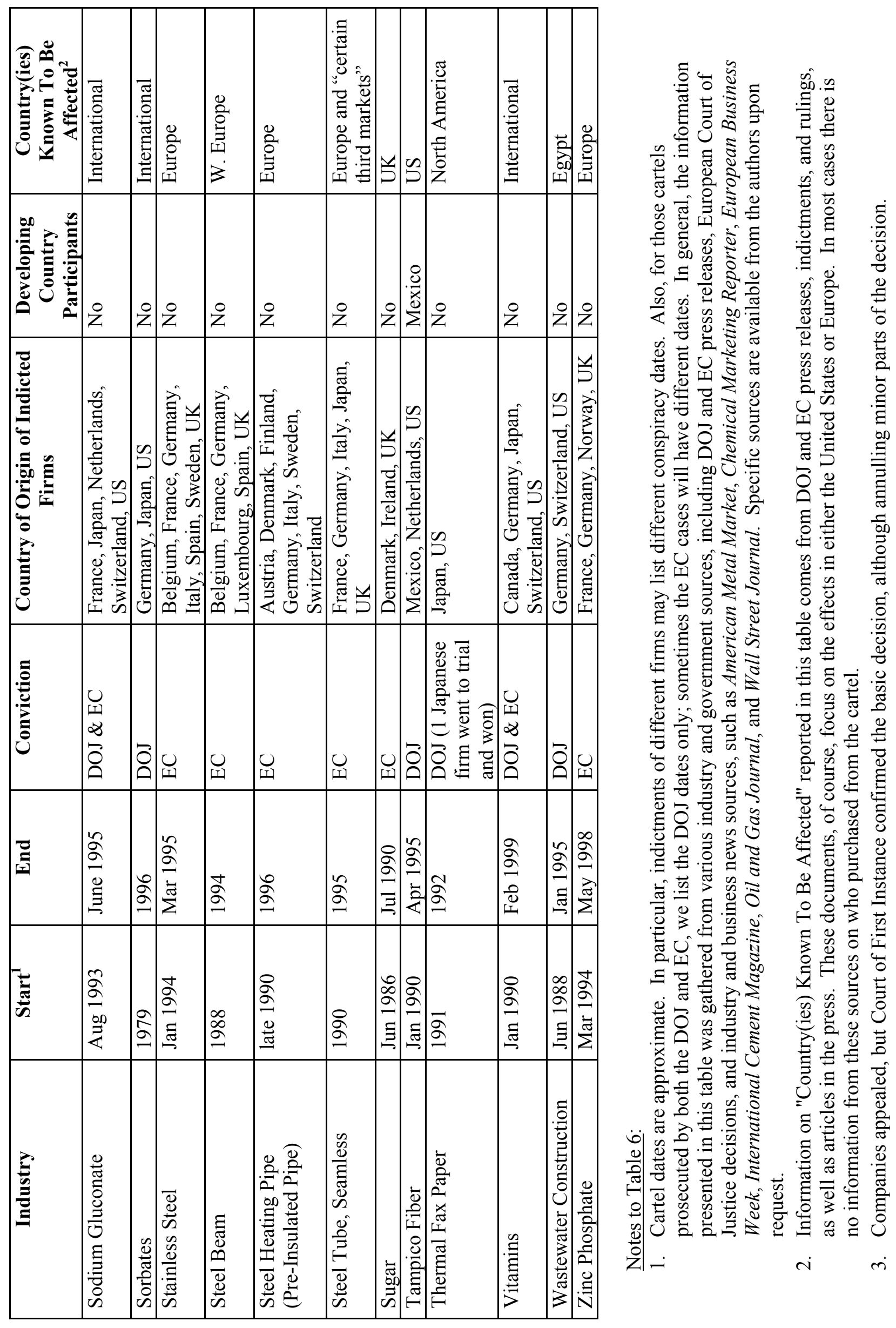




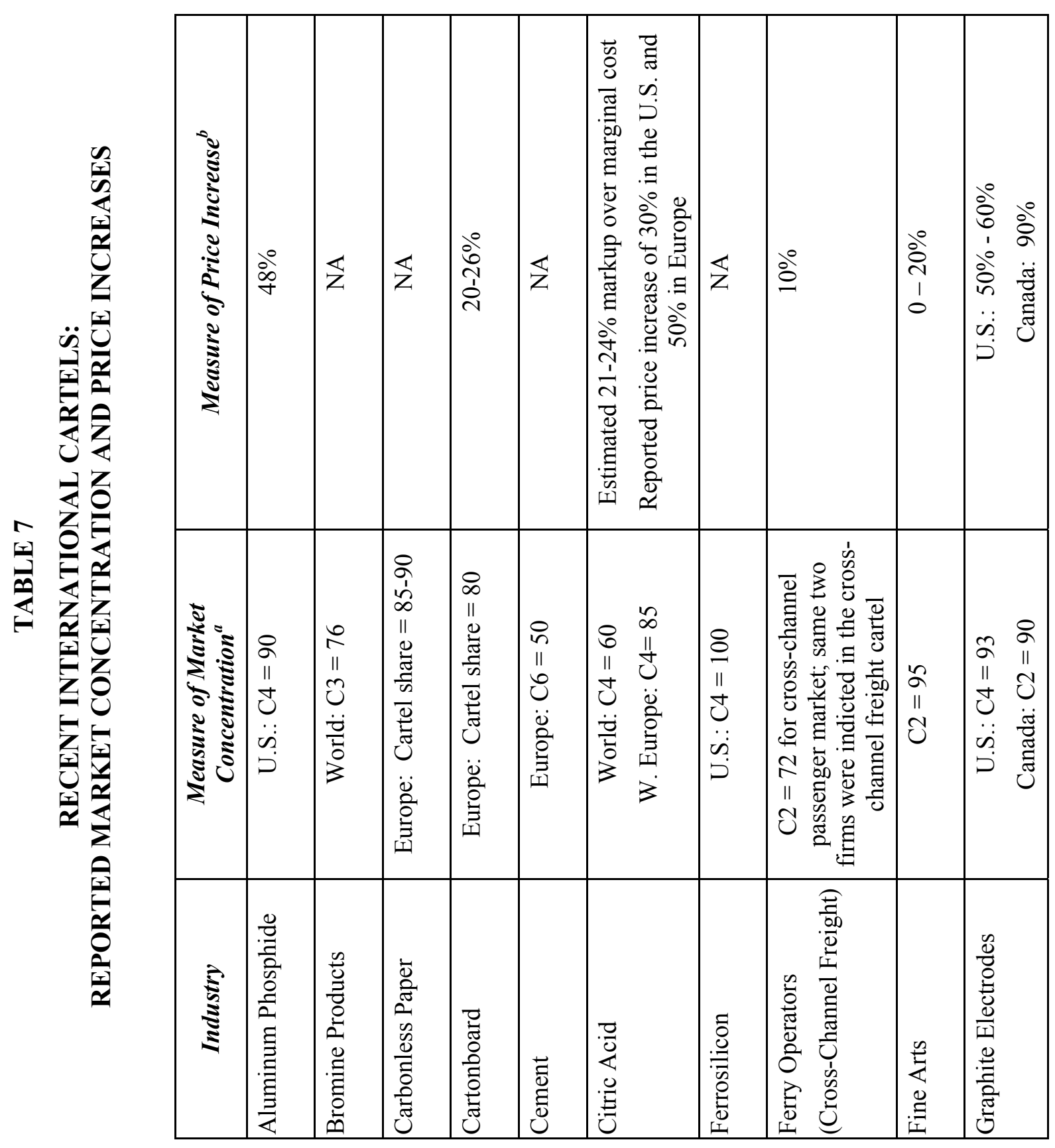




\begin{tabular}{|c|c|c|c|c|c|c|c|c|c|c|}
\hline 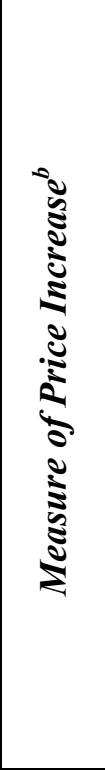 & $\mathbb{z}$ & $\mathbb{z}$ & 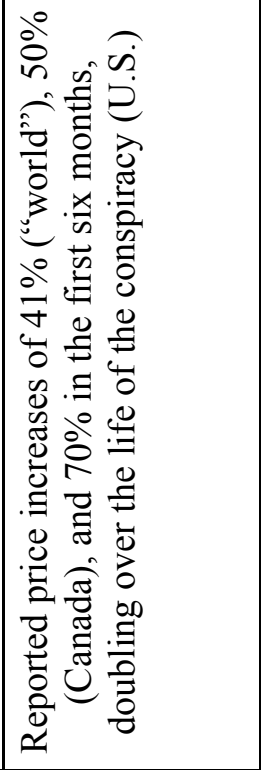 & $\overleftrightarrow{\mathrm{z}}$ & $\mathbb{z}$ & $\overleftrightarrow{z}$ & $\mathbb{z}$ & $\begin{array}{l}\text { oे } \\
\text { ले } \\
\dot{m}\end{array}$ & 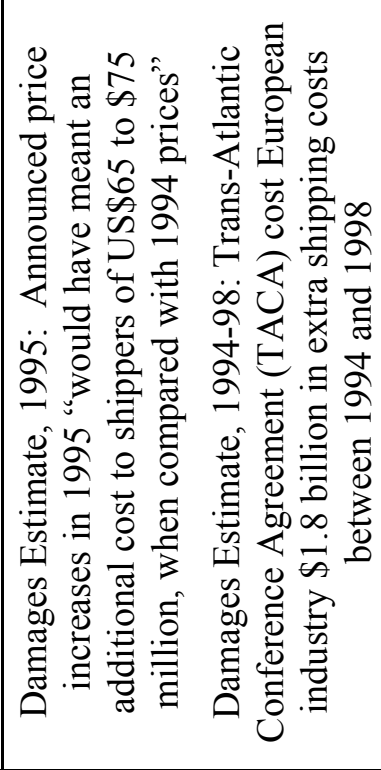 & $\sqrt{z}$ \\
\hline 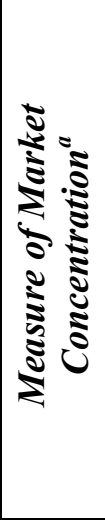 & 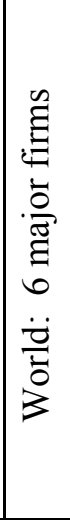 & $\begin{array}{l}n \\
\alpha \\
11 \\
\tilde{\delta} \\
\ddot{n} \\
\tilde{n}\end{array}$ & 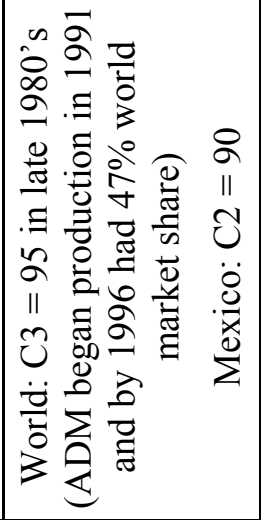 & 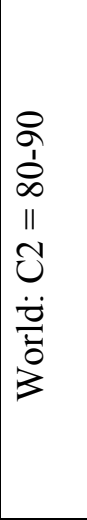 & $\begin{array}{l}\stackrel{Q}{\Omega} \\
\hat{\imath} \\
\tilde{U} \\
\ddot{n} \\
\ddot{n}\end{array}$ & 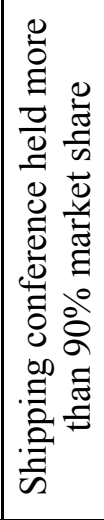 & 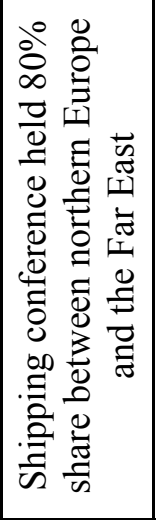 & $\begin{array}{l}8 \\
\text { II } \\
0\end{array}$ & 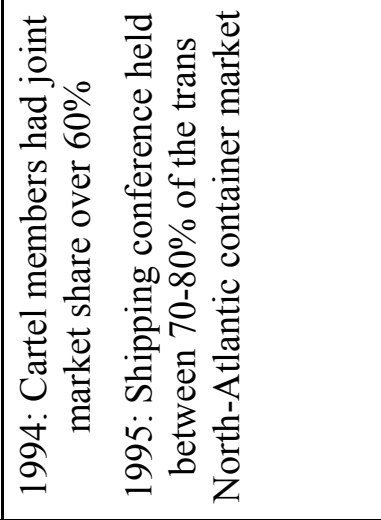 & $\begin{array}{l}8 \\
\text { II } \\
\tilde{U} \\
\ddot{\nu} \\
\ddot{\nu} \\
\dot{\nu}\end{array}$ \\
\hline $\begin{array}{l}\text { है } \\
\text { है } \\
\text { ह }\end{array}$ & 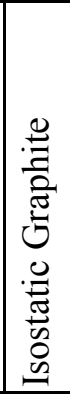 & 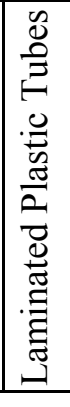 & 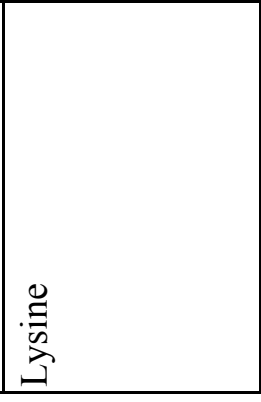 & 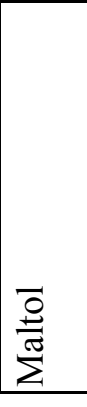 & 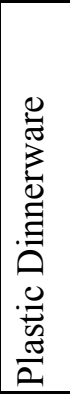 & 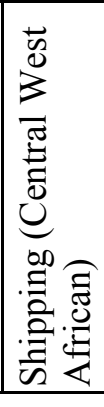 & 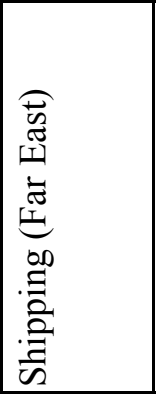 & 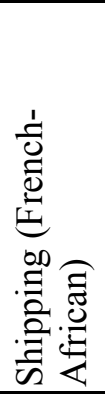 & 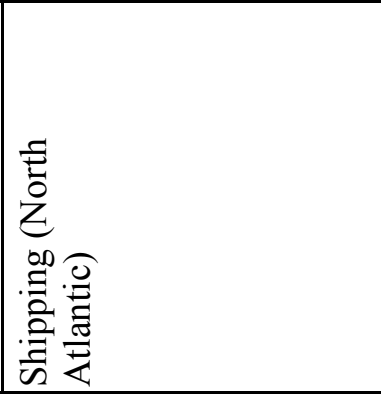 & 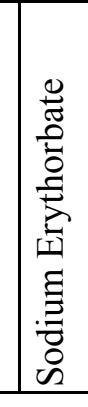 \\
\hline
\end{tabular}




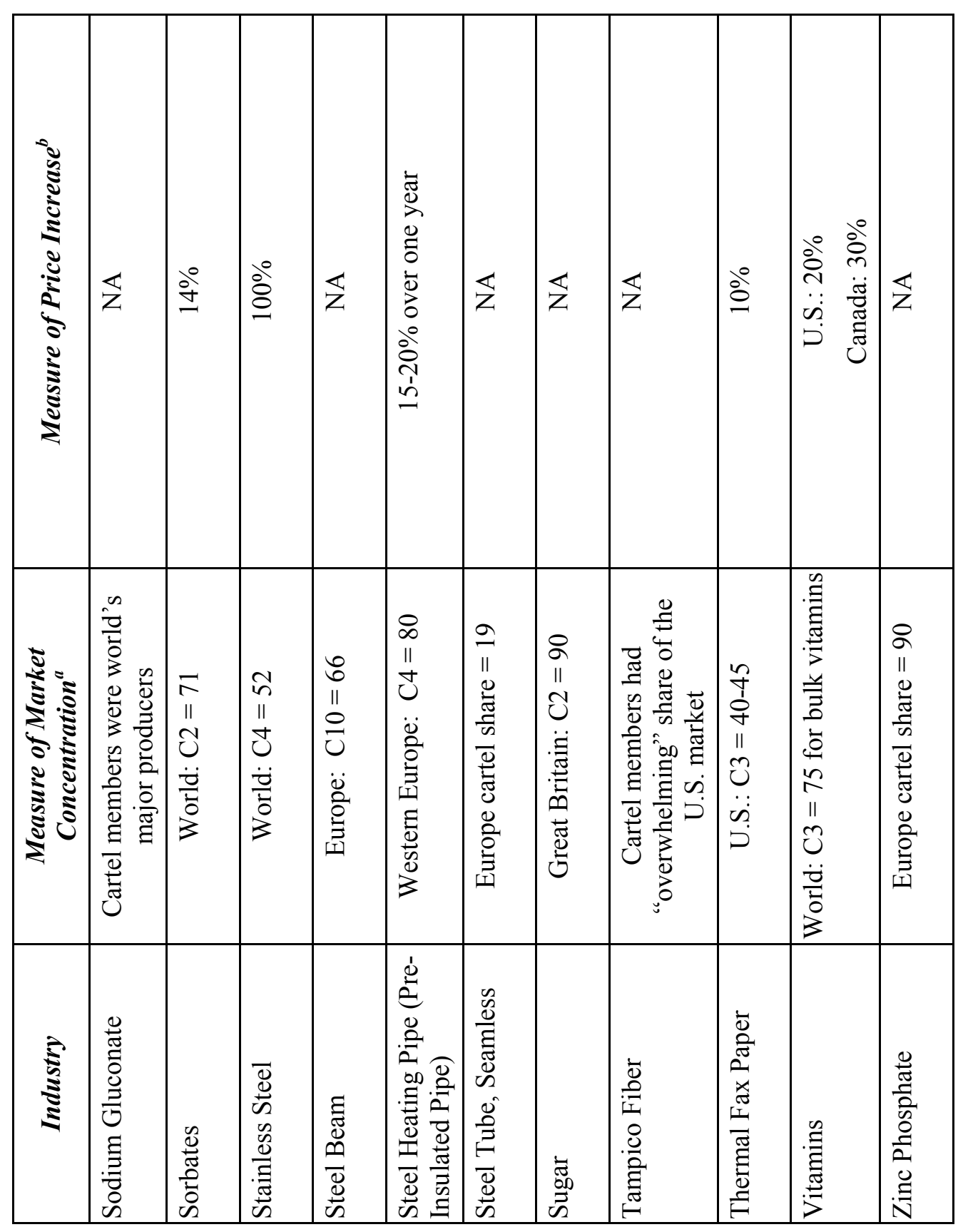




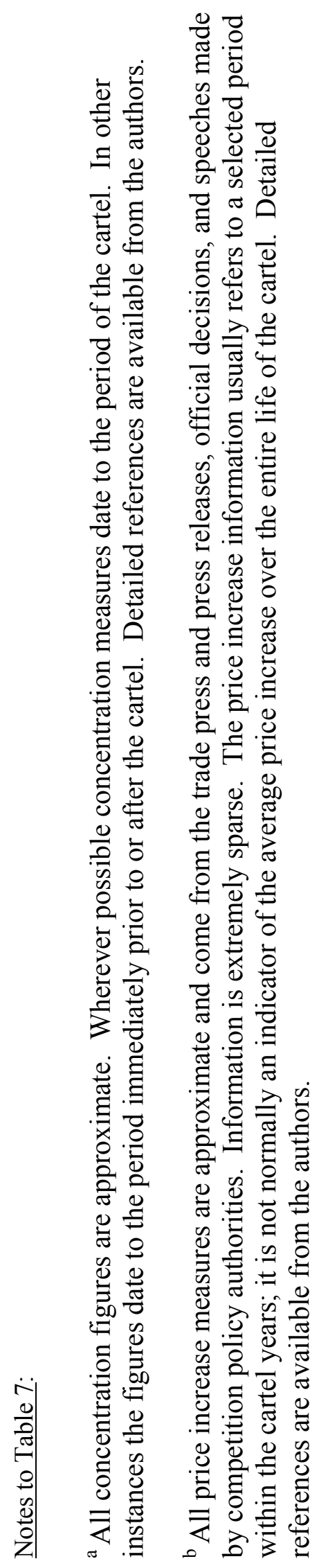




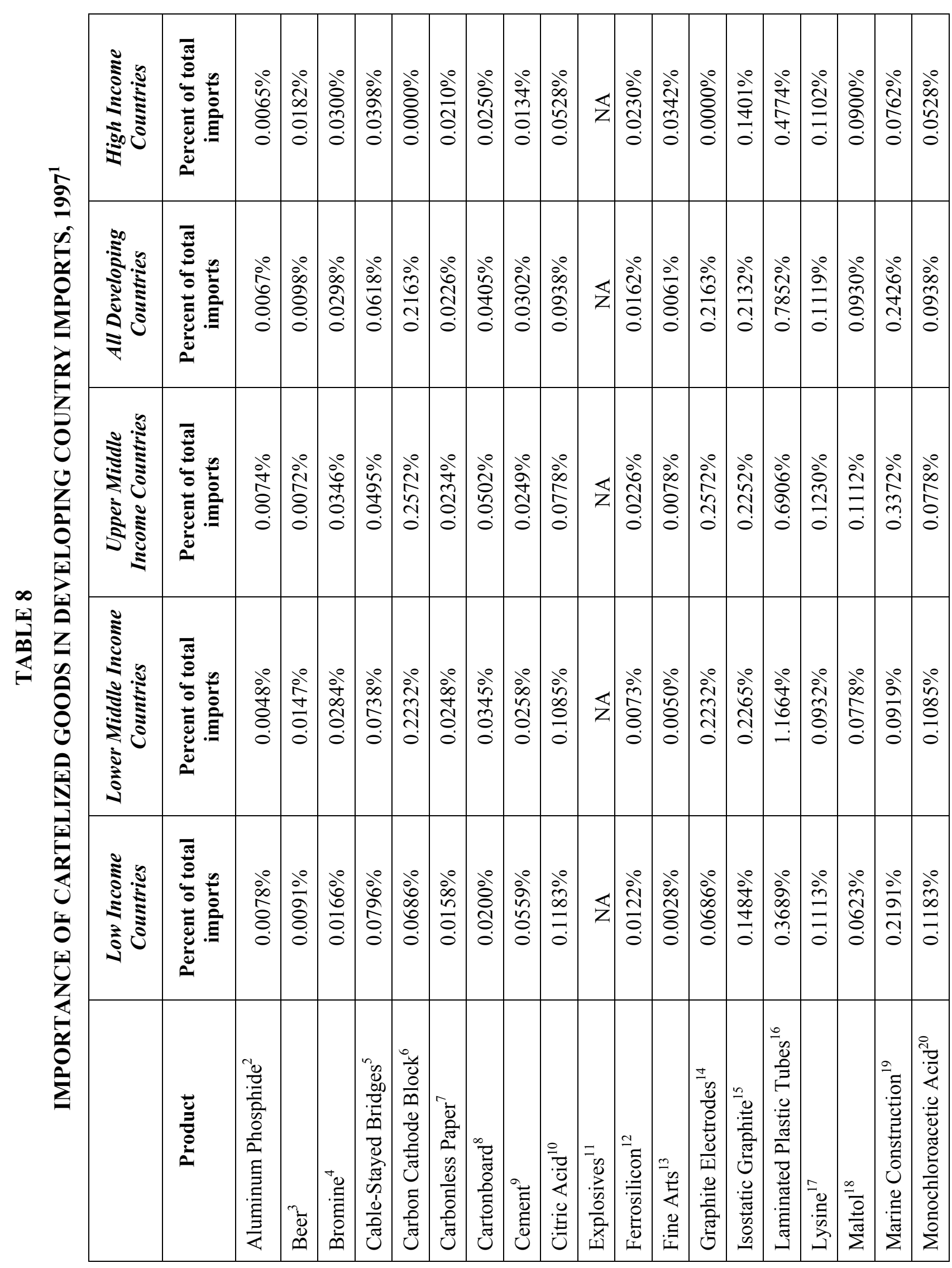




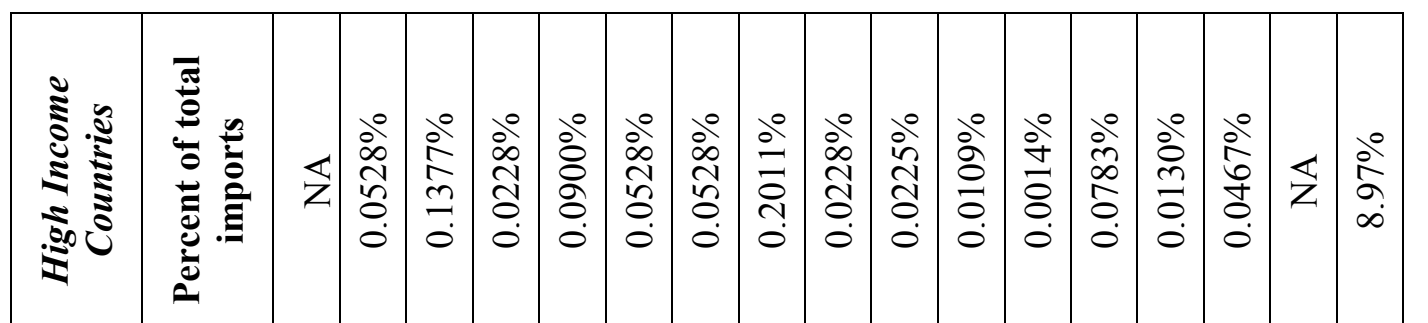

\begin{tabular}{|c|c|c|c|c|c|c|c|c|c|c|c|c|c|c|c|c|c|c|}
\hline 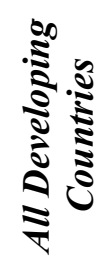 & 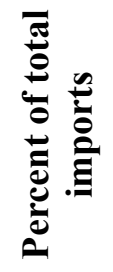 & $\overleftrightarrow{Z}$ & $\begin{array}{l}\partial_{0}^{0} \\
\infty \\
\\
\hat{o} \\
\dot{0}\end{array}$ & 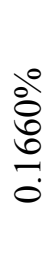 & 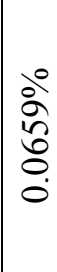 & $\begin{array}{l}\stackrel{0}{0} \\
\text { on } \\
\text { ô } \\
0\end{array}$ & $\begin{array}{l}\stackrel{0}{ } \\
\infty \\
\\
\stackrel{\partial}{0} \\
\dot{0}\end{array}$ & $\begin{array}{l}\stackrel{\circ}{ } \\
\infty \\
\\
\stackrel{0}{0} \\
\dot{0}\end{array}$ & $\begin{array}{l}\stackrel{0}{0} \\
\dot{0} \\
\dot{0} \\
\dot{0}\end{array}$ & 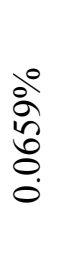 & $\begin{array}{l}\partial^{0} \\
\tilde{n} \\
\tilde{n} \\
0 \\
0\end{array}$ & $\begin{array}{l}\stackrel{0}{ } \\
\infty \\
\stackrel{0}{+} \\
\dot{0} \\
\dot{0}\end{array}$ & $\begin{array}{l}\stackrel{8}{0} \\
\frac{0}{8} \\
0 \\
0\end{array}$ & 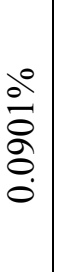 & $\begin{array}{l}\frac{0}{\sigma} \\
\frac{0}{0} \\
0\end{array}$ & $\begin{array}{l}\stackrel{0}{8} \\
\text { } \\
\text { ᄋ } \\
\dot{0}\end{array}$ & $\overleftrightarrow{Z}$ & $\begin{array}{l}\stackrel{\circ}{a} \\
\stackrel{a}{a}\end{array}$ \\
\hline
\end{tabular}

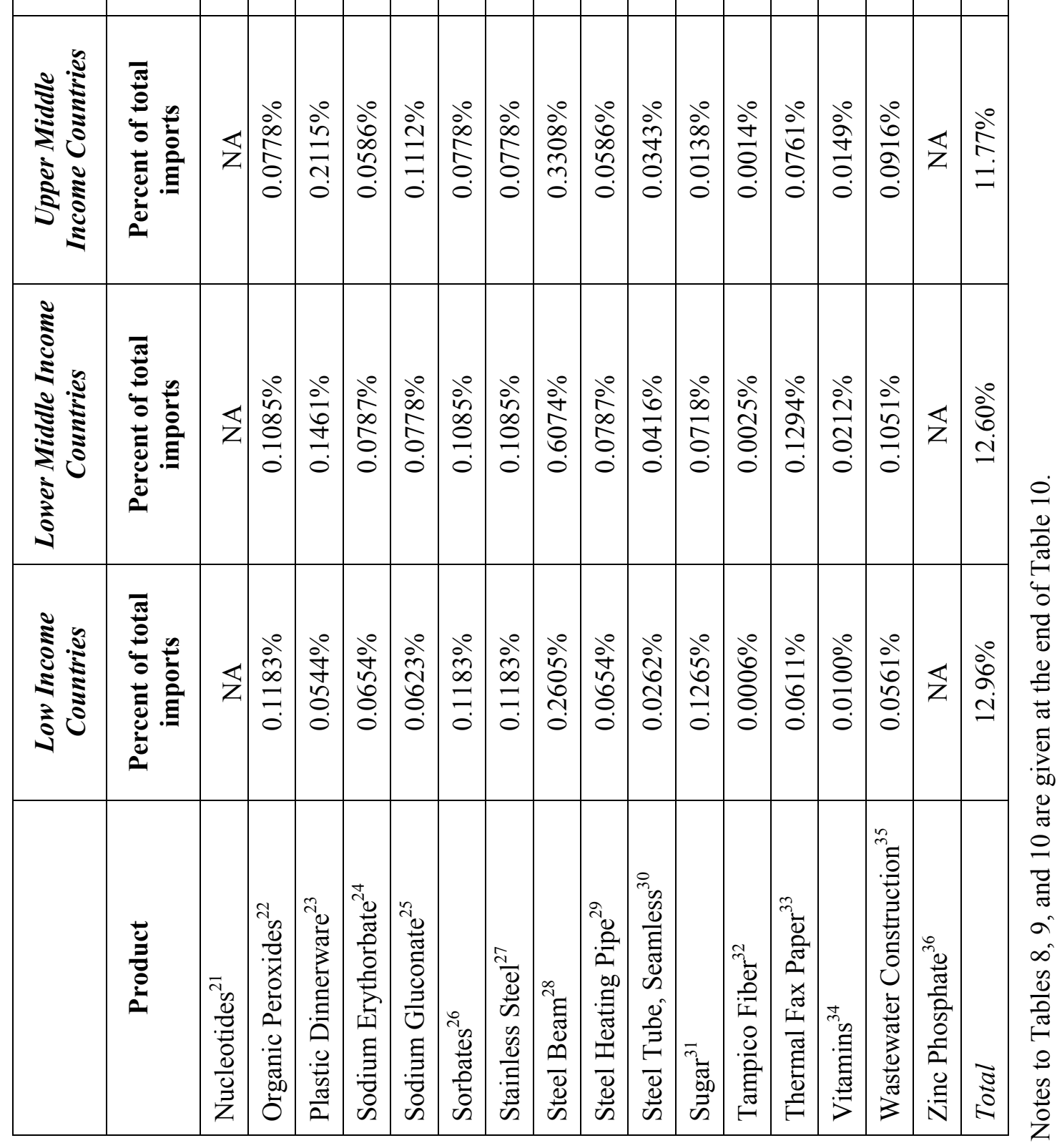




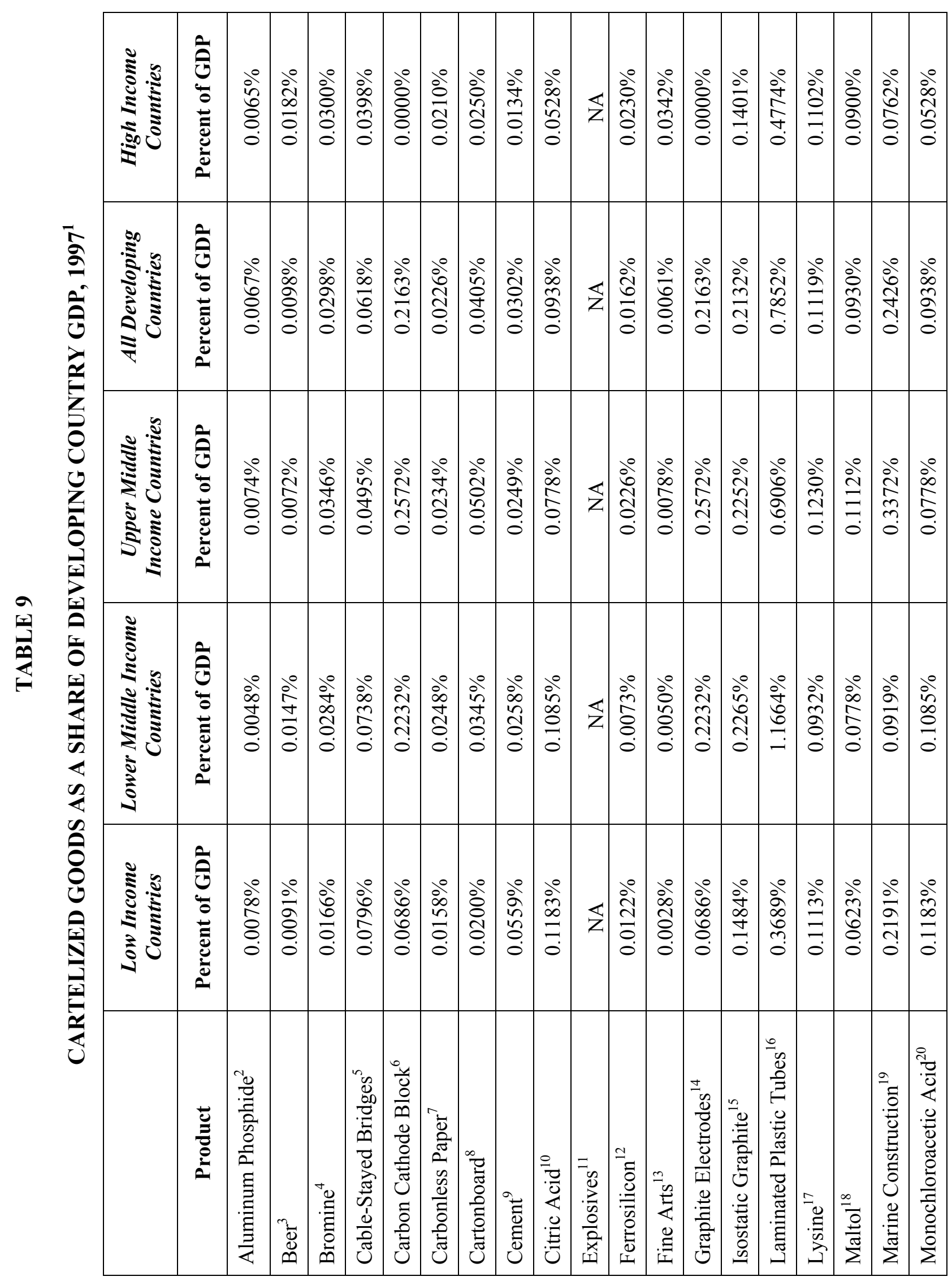




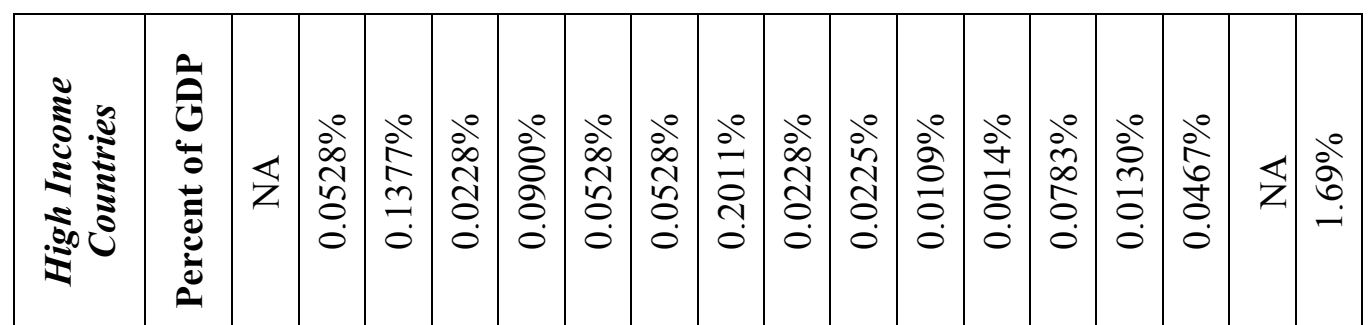

\begin{tabular}{|c|c|c|c|c|c|c|c|c|c|c|c|c|c|c|c|c|c|c|}
\hline 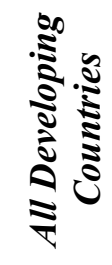 & 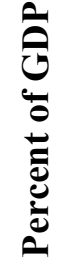 & $\overleftrightarrow{Z}$ & $\begin{array}{l}\stackrel{0}{\circ} \\
\infty \\
\stackrel{2}{0} \\
\dot{0}\end{array}$ & $\begin{array}{l}\stackrel{0}{0} \\
\stackrel{0}{0} \\
\stackrel{0}{0}\end{array}$ & 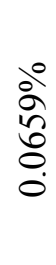 & $\begin{array}{l}\stackrel{0}{0} \\
\text { ஸे } \\
\stackrel{\partial}{0} \\
0\end{array}$ & $\begin{array}{l}\stackrel{0}{0} \\
\infty \\
\\
\stackrel{0}{0} \\
\dot{0}\end{array}$ & $\begin{array}{l}\stackrel{0}{ } \\
\infty \\
\\
\stackrel{0}{0} \\
\dot{0}\end{array}$ & $\begin{array}{l}\stackrel{0}{\dot{b}} \\
\dot{0} \\
\dot{0} \\
\dot{0}\end{array}$ & 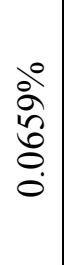 & $\begin{array}{l}\stackrel{0}{ } \\
\hat{n} \\
\tilde{n} \\
\text { ô } \\
0\end{array}$ & $\begin{array}{l}\stackrel{0}{ } \\
\infty \\
\stackrel{0}{0} \\
\dot{0} \\
\dot{0}\end{array}$ & $\begin{array}{l}\stackrel{8}{0} \\
\frac{0}{8} \\
0\end{array}$ & $\begin{array}{l}\frac{0}{\circ} \\
\text { } \\
\text { ஓे } \\
\dot{0}\end{array}$ & $\frac{0^{0}}{\sigma 0}$ & $\begin{array}{l}\stackrel{0}{8} \\
\text { ᄋ̊ } \\
\text { ᄋ } \\
\dot{0}\end{array}$ & $\overleftrightarrow{Z}$ & $\frac{0}{\infty}$ \\
\hline
\end{tabular}

\begin{tabular}{|c|c|c|c|c|c|c|c|c|c|c|c|c|c|c|c|c|c|c|}
\hline 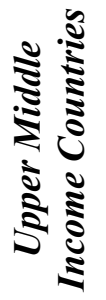 & 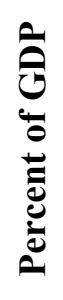 & $\overleftrightarrow{Z}$ & $\begin{array}{l}\stackrel{0}{0} \\
\infty \\
\hat{S} \\
0 \\
0\end{array}$ & $\begin{array}{l}\stackrel{0}{n} \\
\stackrel{i}{z} \\
0\end{array}$ & $\begin{array}{l}\stackrel{0}{0} \\
\dot{0} \\
0 \\
0 \\
0\end{array}$ & 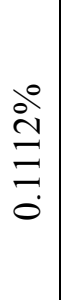 & $\begin{array}{l}\stackrel{0}{\infty} \\
\stackrel{0}{\$} \\
\stackrel{0}{0} \\
\dot{0}\end{array}$ & $\begin{array}{l}\stackrel{0}{\infty} \\
\stackrel{0}{\hat{S}} \\
\stackrel{0}{0} \\
0\end{array}$ & 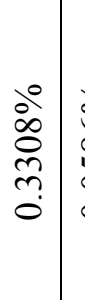 & 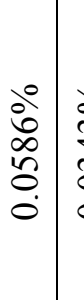 & 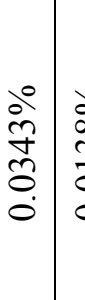 & $\begin{array}{l}0 \\
0 \\
\infty \\
m \\
0 \\
0 \\
0\end{array}$ & \begin{tabular}{l|l}
$\stackrel{0}{0}$ & 0 \\
\\
$\delta$
\end{tabular} & $\begin{array}{lll}0 & 0 \\
\frac{0}{0} & 0 \\
0 & 0 \\
0 & 0 \\
0 & 0\end{array}$ & 命 & $\begin{array}{l}0 \\
\frac{b}{0} \\
\frac{b}{6} \\
0 \\
0\end{array}$ & $\overleftrightarrow{\mathrm{Z}}$ & $\frac{0}{i}$ \\
\hline 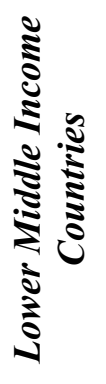 & 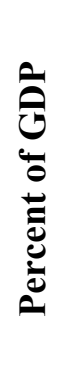 & $\mathbb{Z}$ & $\begin{array}{l}0 \\
i \\
\infty \\
0 \\
0 \\
0 \\
0\end{array}$ & $\begin{array}{l}0^{0} \\
0 \\
\dot{0} \\
0\end{array}$ & 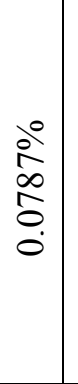 & $\begin{array}{l}0 \\
\infty \\
\infty \\
\hat{s} \\
0 \\
\dot{0}\end{array}$ & $\begin{array}{c}00 \\
0 \\
2 \\
0 \\
0 \\
0 \\
0\end{array}$ & $\begin{array}{l}0 \\
\stackrel{0}{ } \\
\infty \\
\infty \\
0 \\
0 \\
0\end{array}$ & $\begin{array}{l}\stackrel{0}{+} \\
\stackrel{+}{S} \\
\stackrel{8}{0} \\
\dot{0}\end{array}$ & $\begin{array}{l}\frac{0}{\hat{0}} \\
\frac{0}{5} \\
0 \\
0\end{array}$ & $\begin{array}{l}0 ْ \\
\dot{0} \\
\dot{\Xi} \\
\dot{0} \\
\dot{0}\end{array}$ & $\begin{array}{l}\stackrel{0}{0} \\
\infty \\
\overline{\mathbf{N}} \\
0 \\
0\end{array}$ & 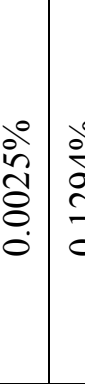 & $\begin{array}{l}\stackrel{\circ}{0} \\
\stackrel{\circ}{2} \\
\stackrel{0}{0}\end{array}$ & 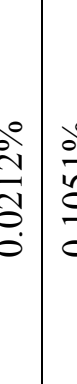 & $\begin{array}{l}\frac{0}{0} \\
\frac{0}{2} \\
0\end{array}$ & 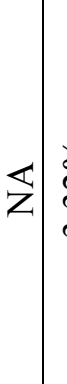 & 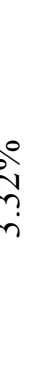 \\
\hline 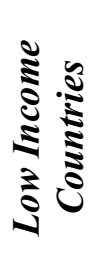 & 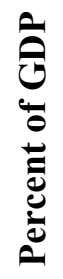 & $\mathbb{Z}$ & $\begin{array}{l}\stackrel{0}{0} \\
\infty \\
\infty \\
= \\
0\end{array}$ & $\begin{array}{l}\stackrel{0}{+} \\
\dot{J} \\
\stackrel{0}{0} \\
\dot{0}\end{array}$ & 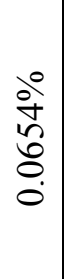 & 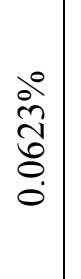 & $\begin{array}{l}\dot{0}^{0} \\
\infty \\
\equiv \\
\dot{0}\end{array}$ & $\begin{array}{l}\dot{0}^{0} \\
\dot{\infty} \\
\Xi \\
\dot{0} \\
\dot{0}\end{array}$ & $\begin{array}{l}\stackrel{0}{0} \\
\stackrel{2}{0} \\
\stackrel{0}{0} \\
\stackrel{1}{0}\end{array}$ & $\begin{array}{l}\stackrel{0}{0} \\
\dot{1} \\
\vdots \\
0 \\
0\end{array}$ & 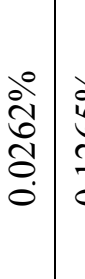 & 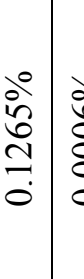 & $\begin{array}{l}0 \\
0 \\
0 \\
8 \\
8 \\
0 \\
0\end{array}$ & $\begin{array}{l}\frac{0}{0} \\
\frac{1}{0} \\
\vdots \\
0\end{array}$ & $\begin{array}{l}b_{0}^{0} \\
0 \\
0 \\
0\end{array}$ & $\begin{array}{l}\frac{0}{0} \\
0 \\
0 \\
0 \\
0\end{array}$ & $\mathbb{Z}$ & $\frac{e^{\circ}}{a}$ \\
\hline & $\begin{array}{l}\tilde{E} \\
\stackrel{\Xi}{0} \\
\stackrel{0}{0}\end{array}$ & 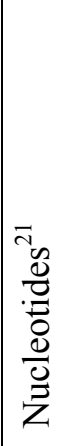 & 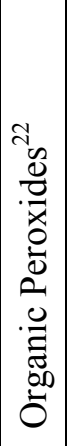 & 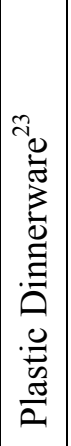 & 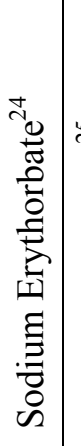 & 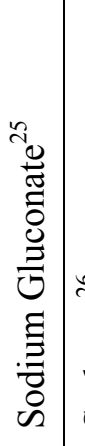 & 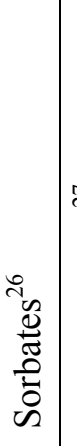 & 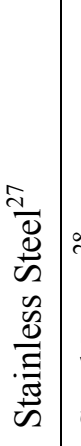 & 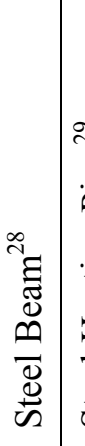 & 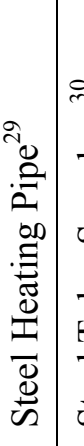 & 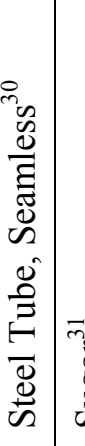 & 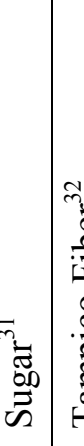 & 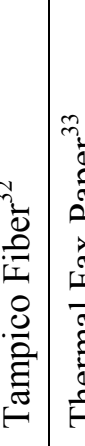 & 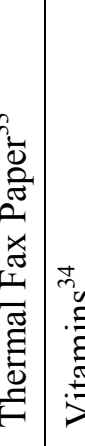 & 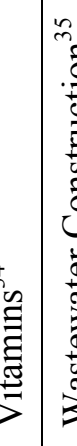 & 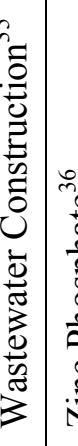 & 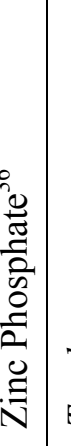 & $\frac{\mathbb{Z}}{0}$ \\
\hline
\end{tabular}




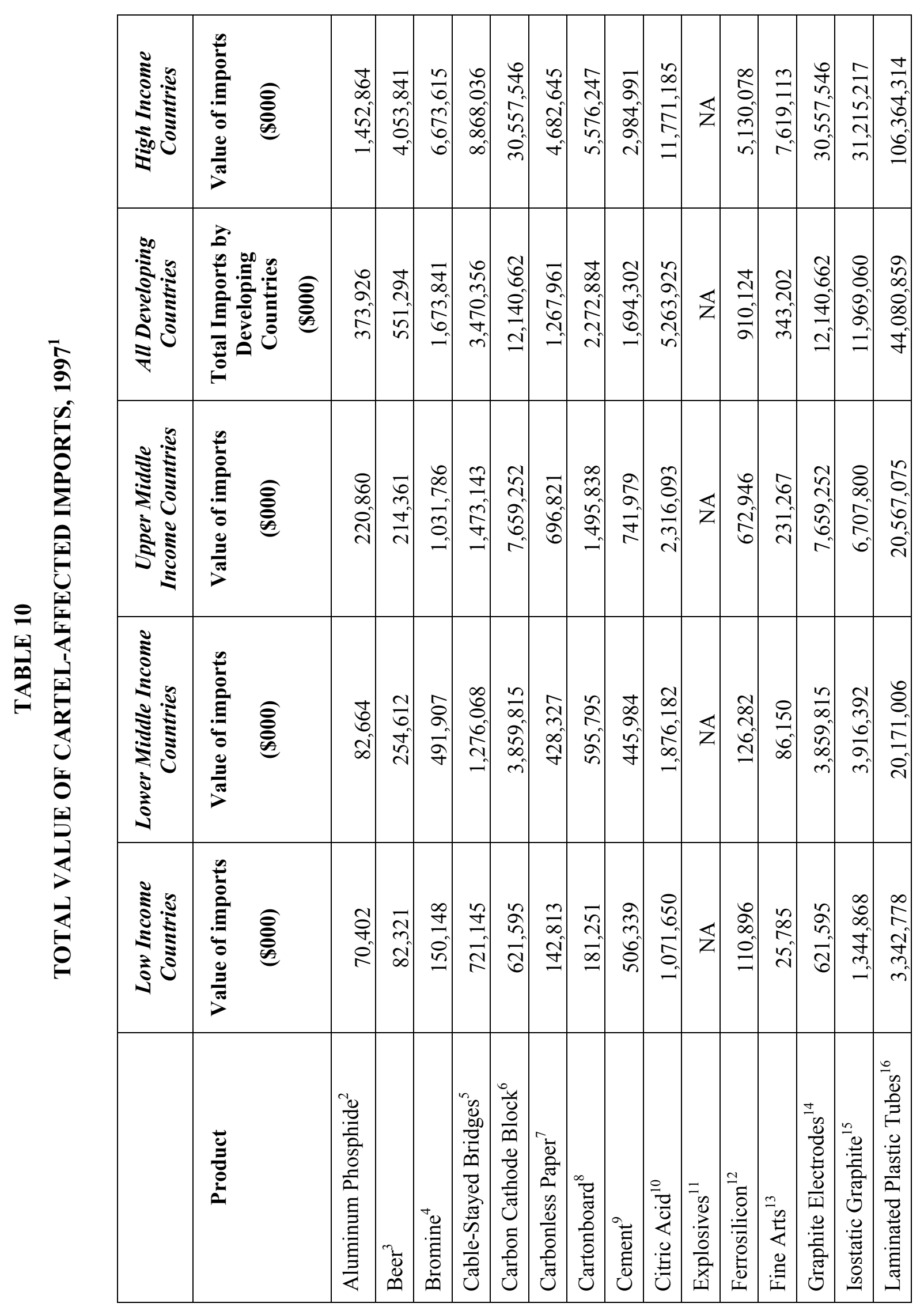




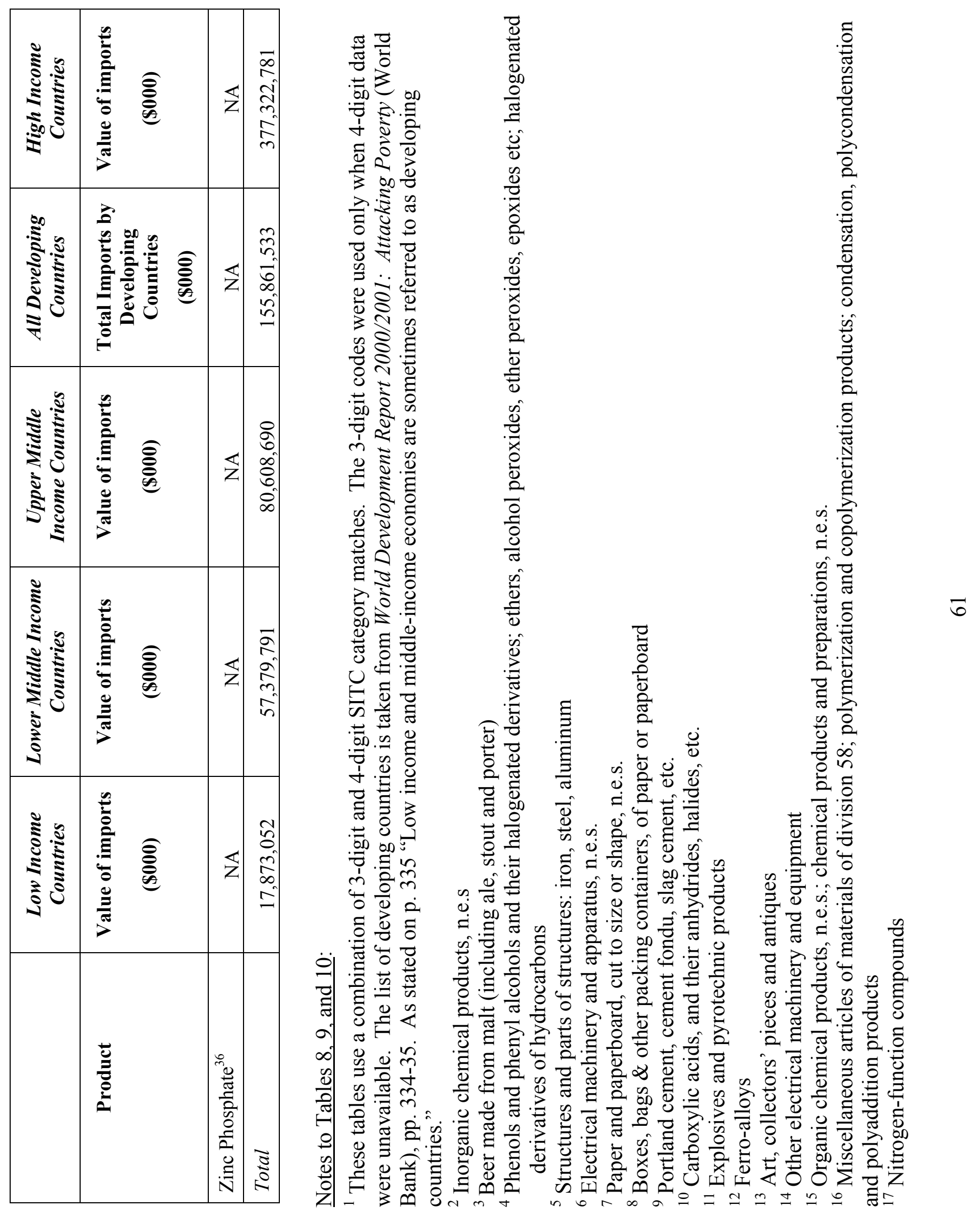




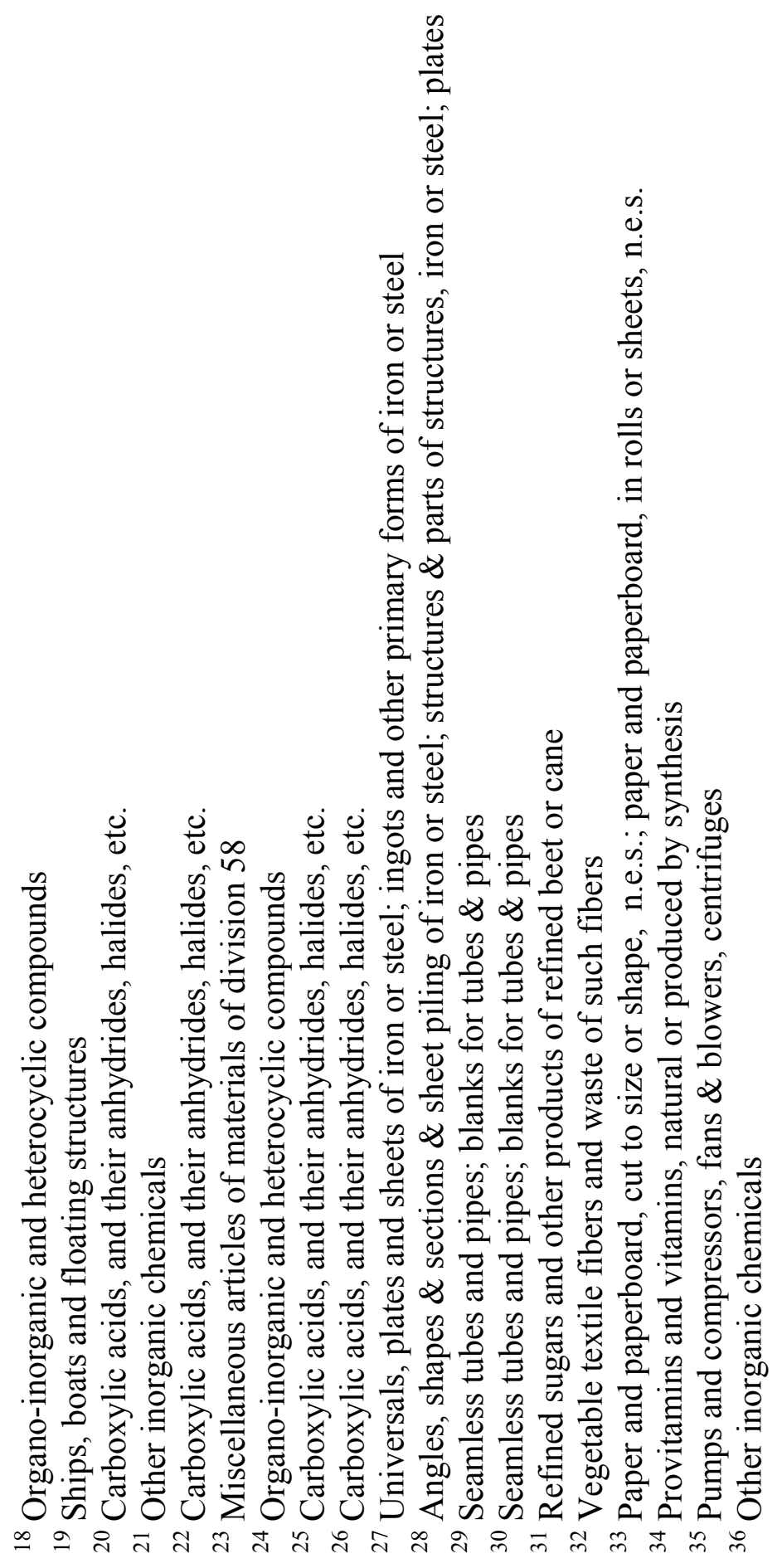




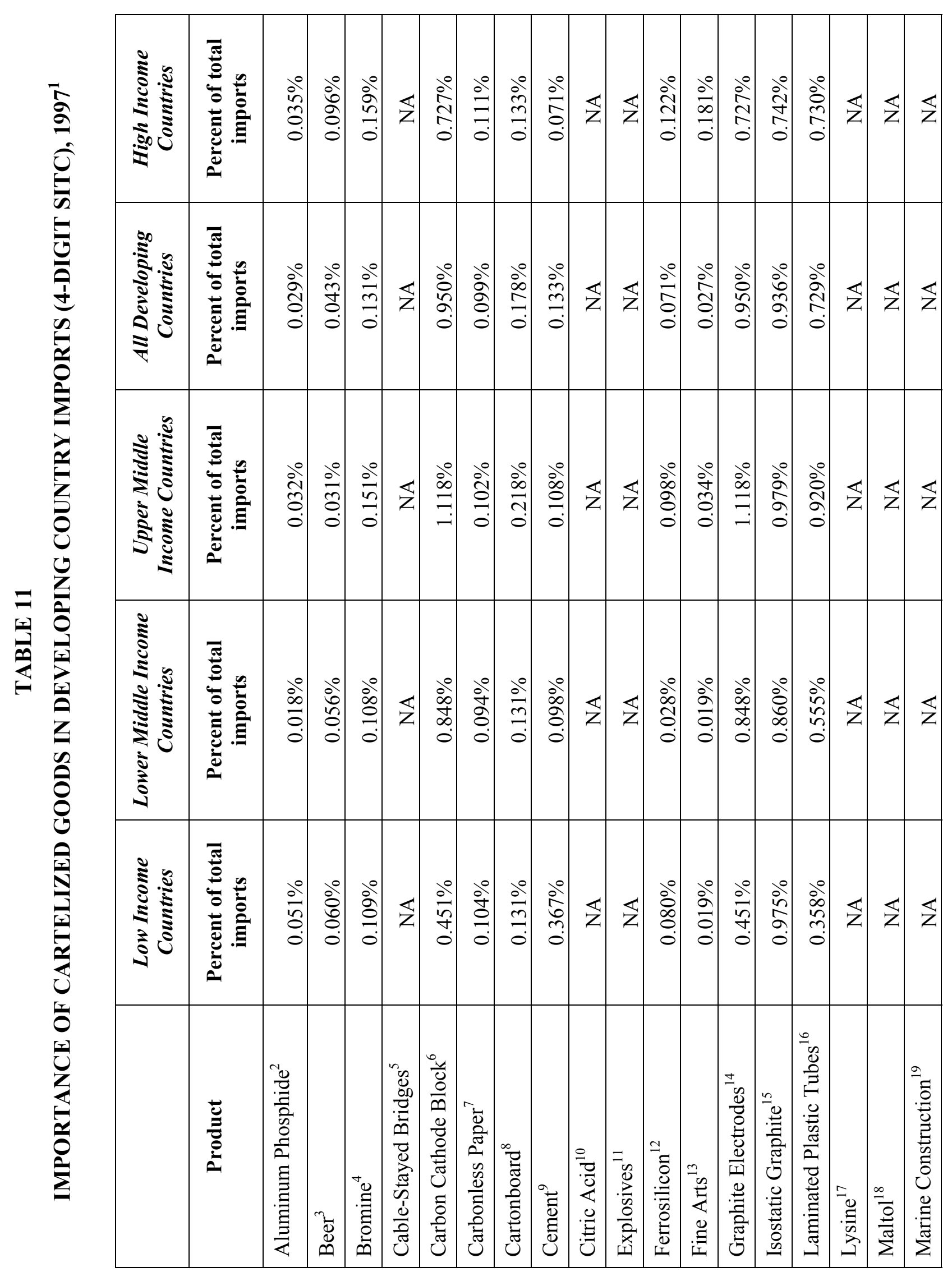




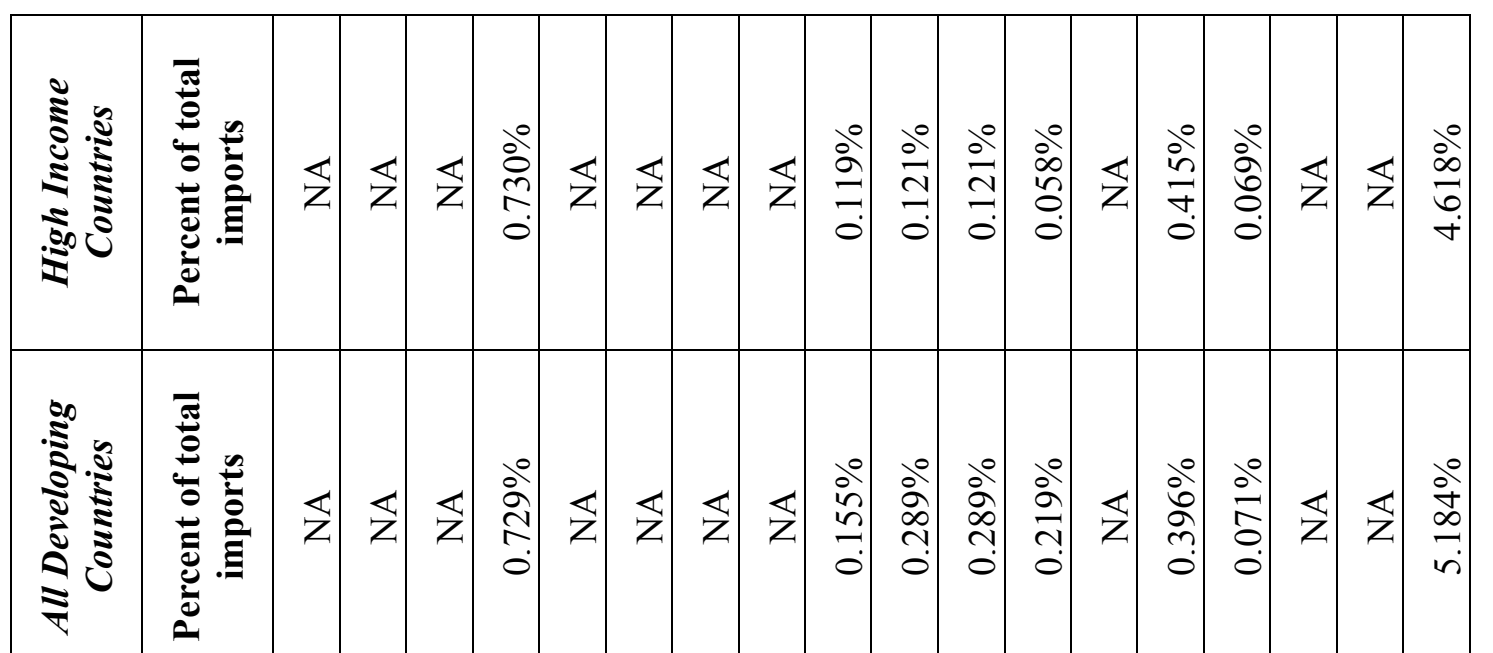

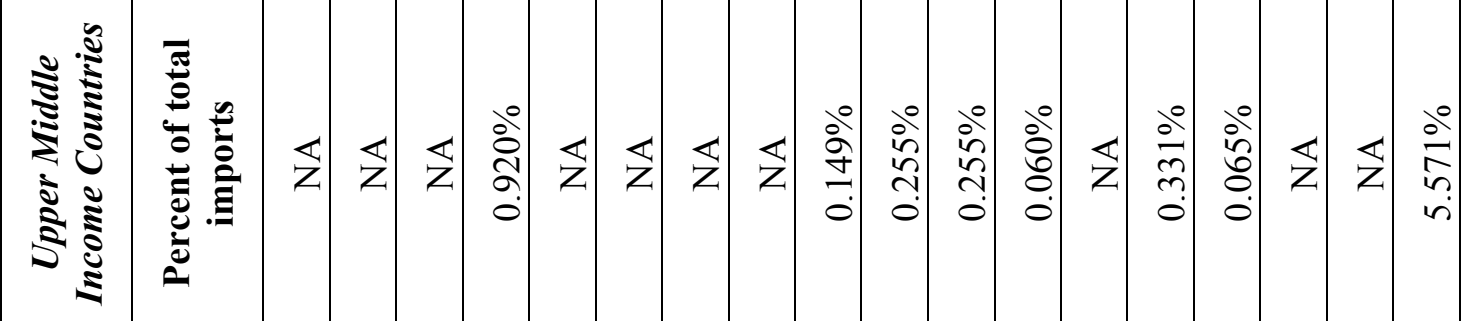

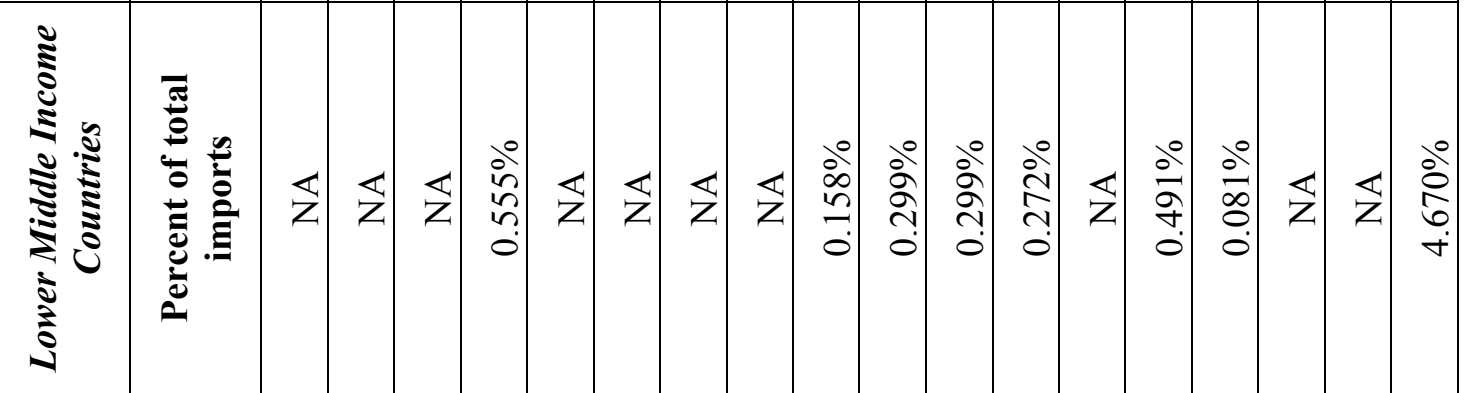

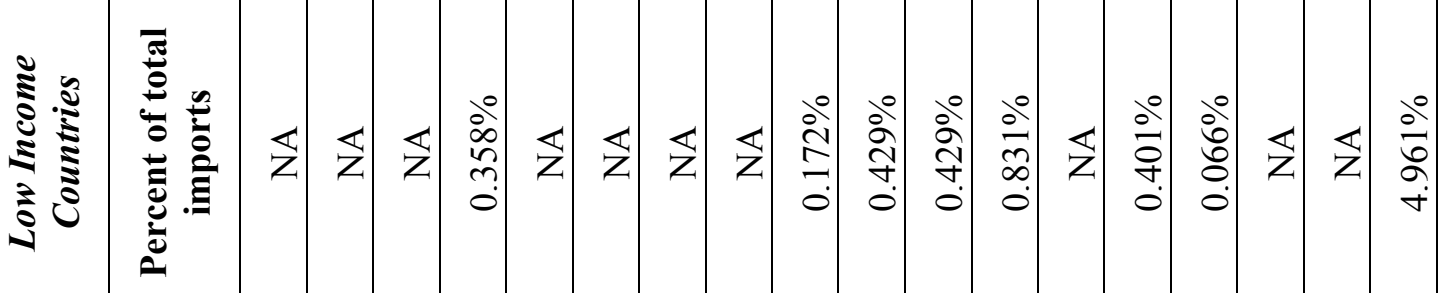

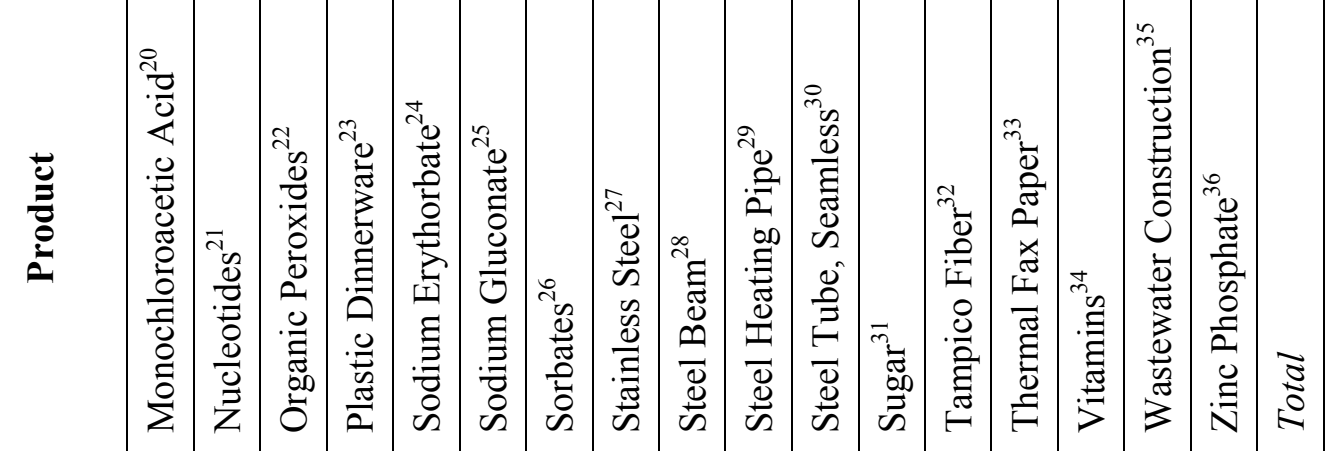




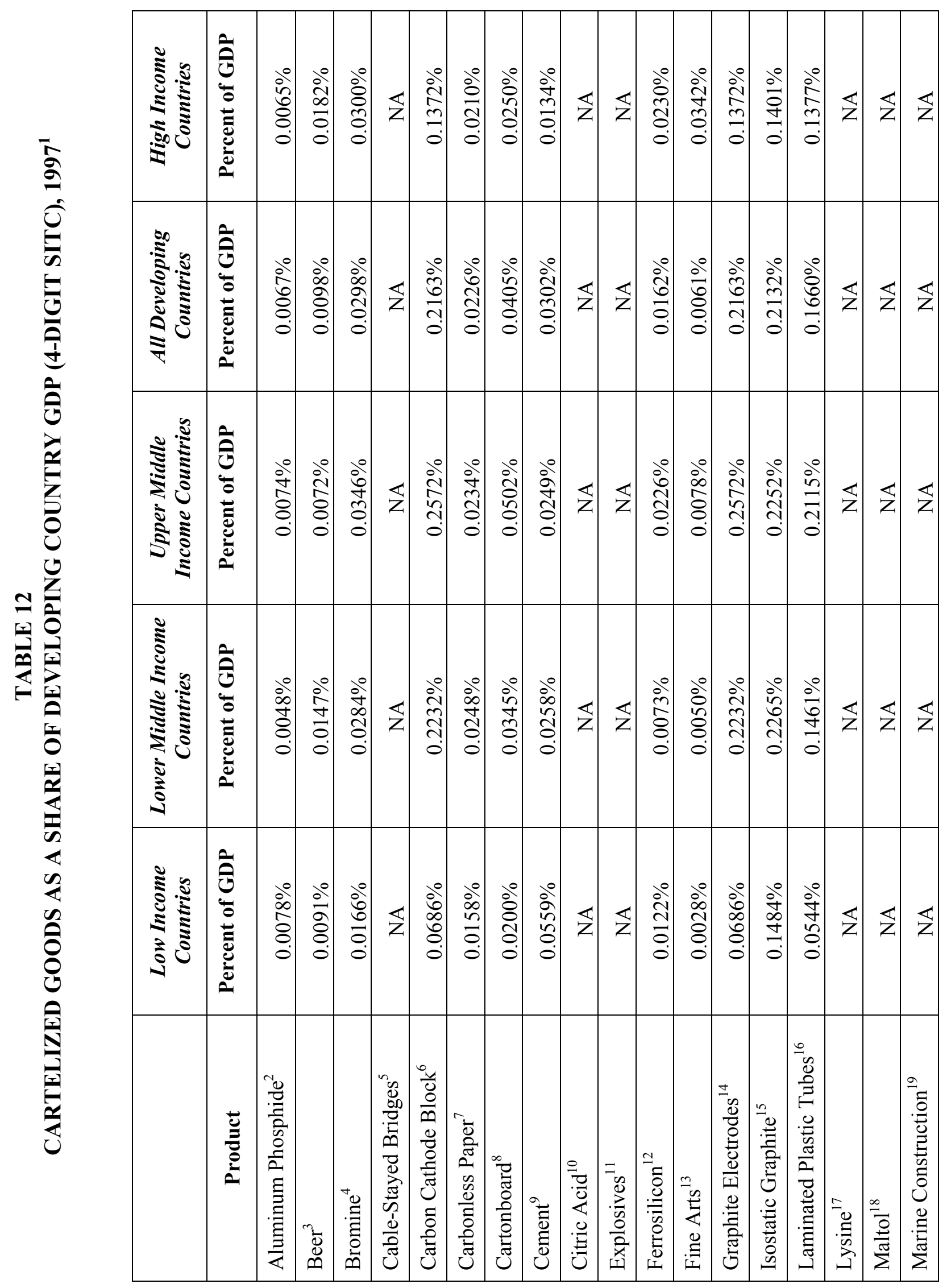




\begin{tabular}{|c|c|c|c|c|c|c|c|c|c|c|}
\hline 辛 & 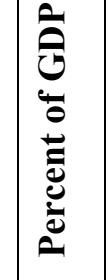 & $\widehat{z}=\mathbb{z}=\frac{z}{z}$ & & & $\bar{z} \mid z$ & 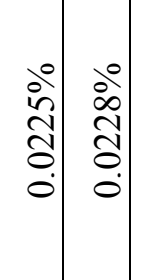 & 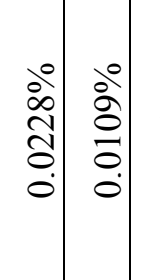 & $\widehat{z}$ & 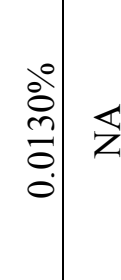 & $\frac{\partial}{z}$ \\
\hline : & 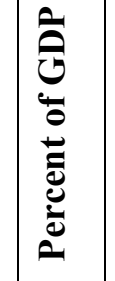 & $\bar{z} \mid \bar{z}=\bar{z}$ & 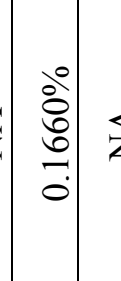 & $\bar{z}|\underline{z}|$ & $\mathbb{z} \mid \mathbb{z}$ & 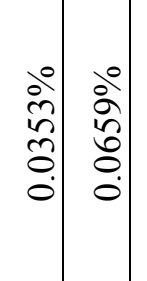 & $\begin{array}{cc}0 \\
0\end{array}$ & $z=\frac{\partial}{\bar{g}}$ & 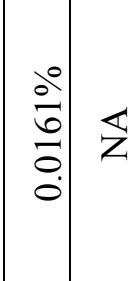 & $\hat{z}$ \\
\hline 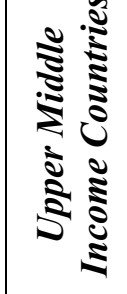 & 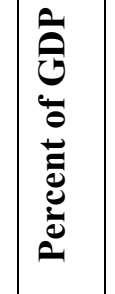 & $\vec{z}|\mathbb{z}| z$ & 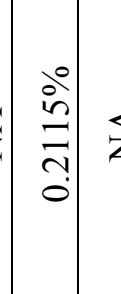 & 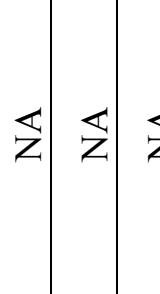 & $\underline{z} \mid \frac{s}{z}$ & 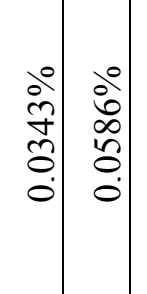 & 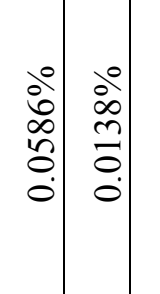 & & 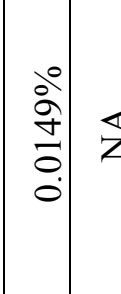 & $\bar{z}=\mathbb{z}$ \\
\hline ไู & 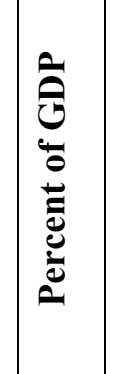 & $\overleftrightarrow{z}|s| z \mid z$ & $\mid$ & & $\mathbb{z} \mid \bar{z}$ & & |con & & 离 & $\widehat{z}$ \\
\hline 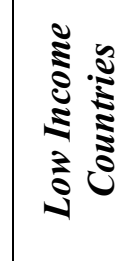 & 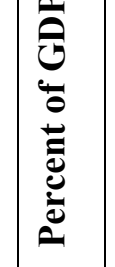 & $z=z$ & : & 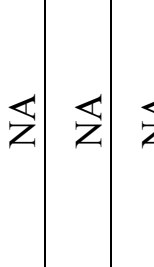 & $\overleftrightarrow{z} \mid \overleftrightarrow{z}$ & 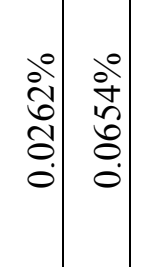 & 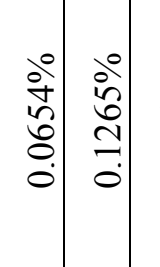 & $\widehat{z}$ & $\begin{array}{ll} & \\
\vdots & \vdots \\
\vdots\end{array}$ & $\vec{z}=\vec{z}$ \\
\hline
\end{tabular}

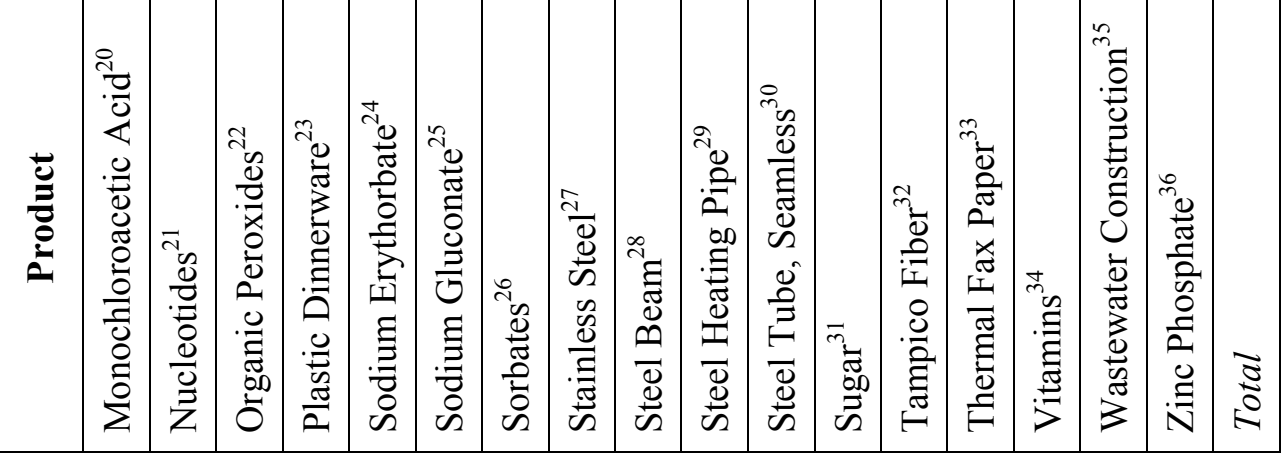




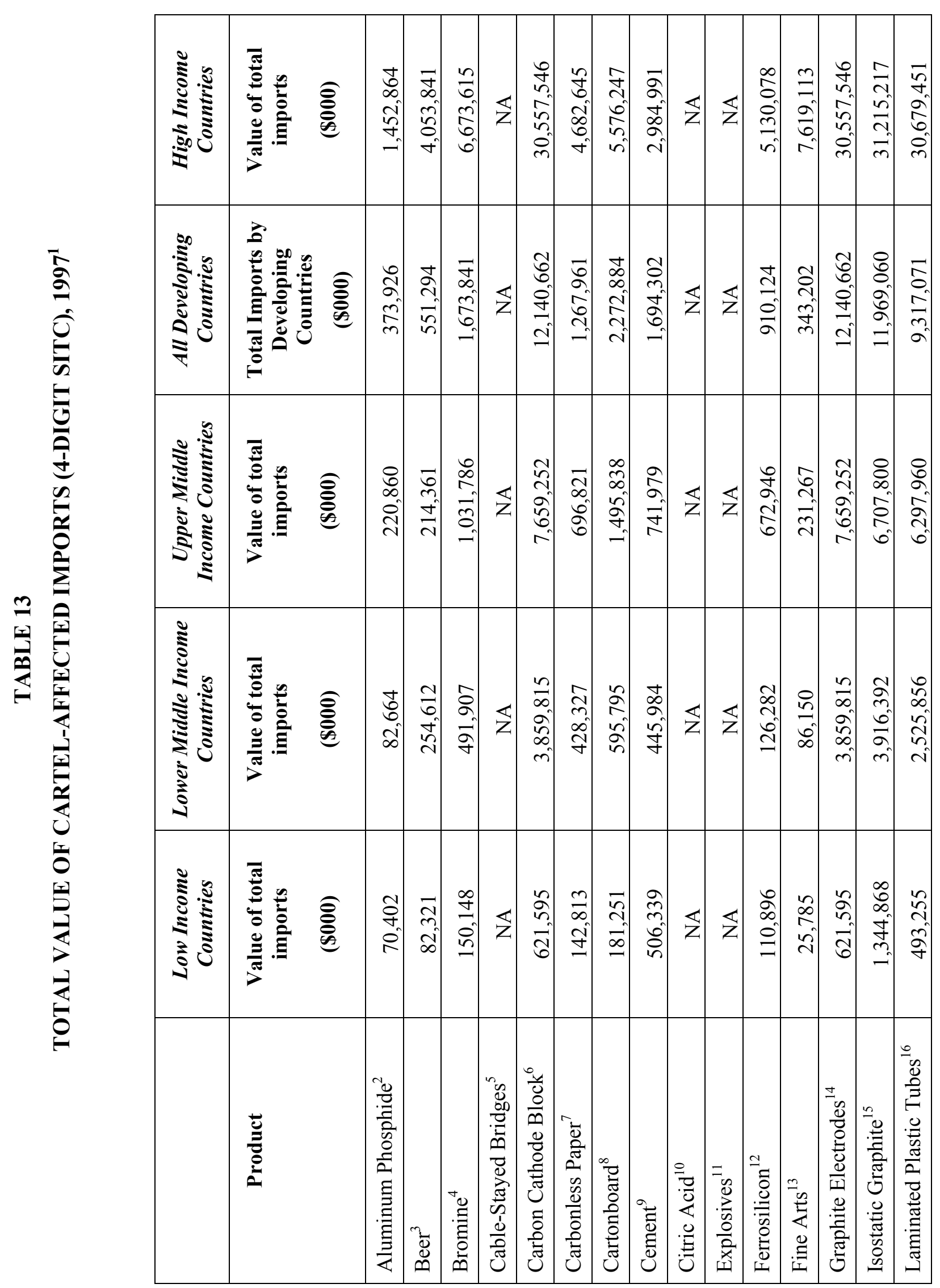




\begin{tabular}{|c|c|c|c|c|c|c|c|c|c|c|c|c|c|c|}
\hline ث. & 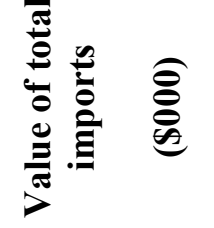 & $\stackrel{s}{z}$ & & & & & $\frac{s}{z}$ & $\mathbb{z}$ & & 年 & 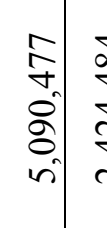 & & 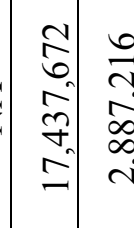 & o. \\
\hline 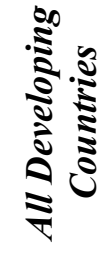 & 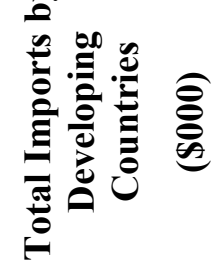 & $\mathbb{z} z$ & & & $\bar{z}$ & & & $\mathbb{z}$ & 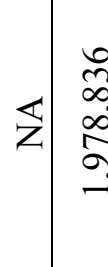 & 0 & : & $\frac{1}{z}$ & 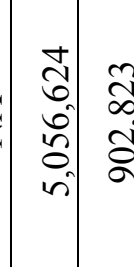 & \\
\hline 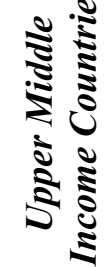 & 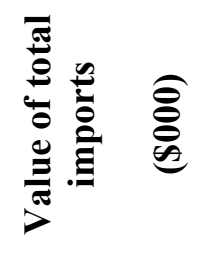 & 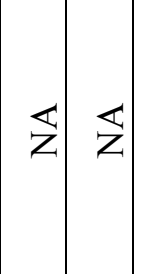 & & & $\stackrel{s}{z}$ & |- & $\bar{z}$ & $\underline{z}$ & & $\stackrel{ \pm}{*}=$ & 望 & & & \\
\hline 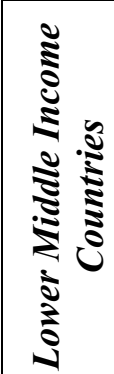 & 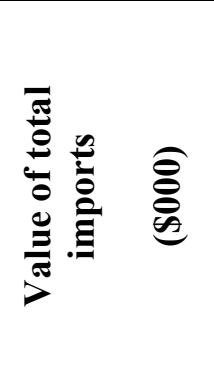 & & & & $\underline{z}$ & & $\bar{z} \mathbf{z}$ & 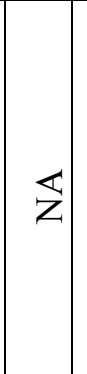 & 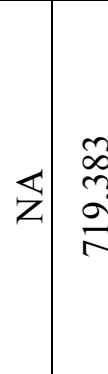 & 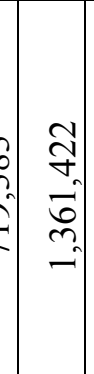 & 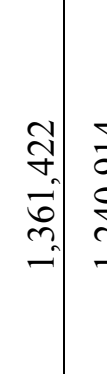 & & & \\
\hline 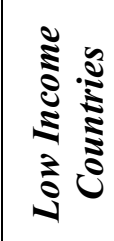 & 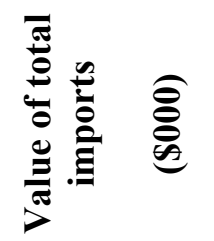 & & & & $\stackrel{\mathbb{z}}{z}$ & & & $\underline{z}$ & & & 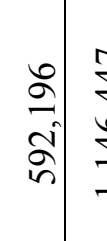 & & & 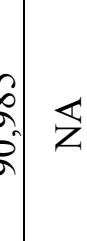 \\
\hline & 产 & 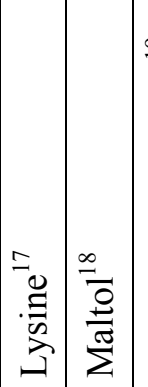 & 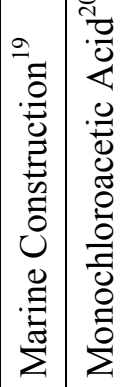 & & 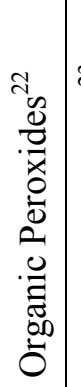 & 索: & 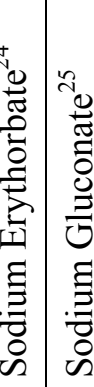 & 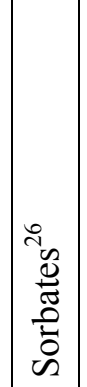 & 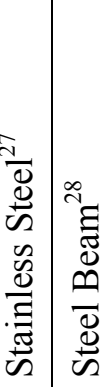 & 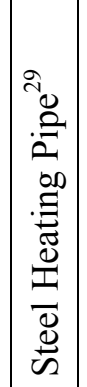 & 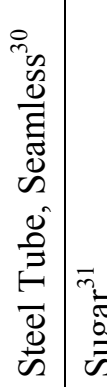 & & 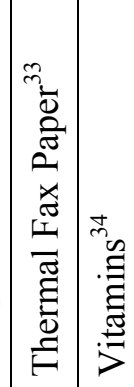 & 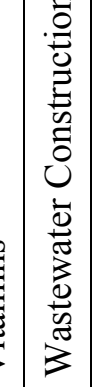 \\
\hline
\end{tabular}



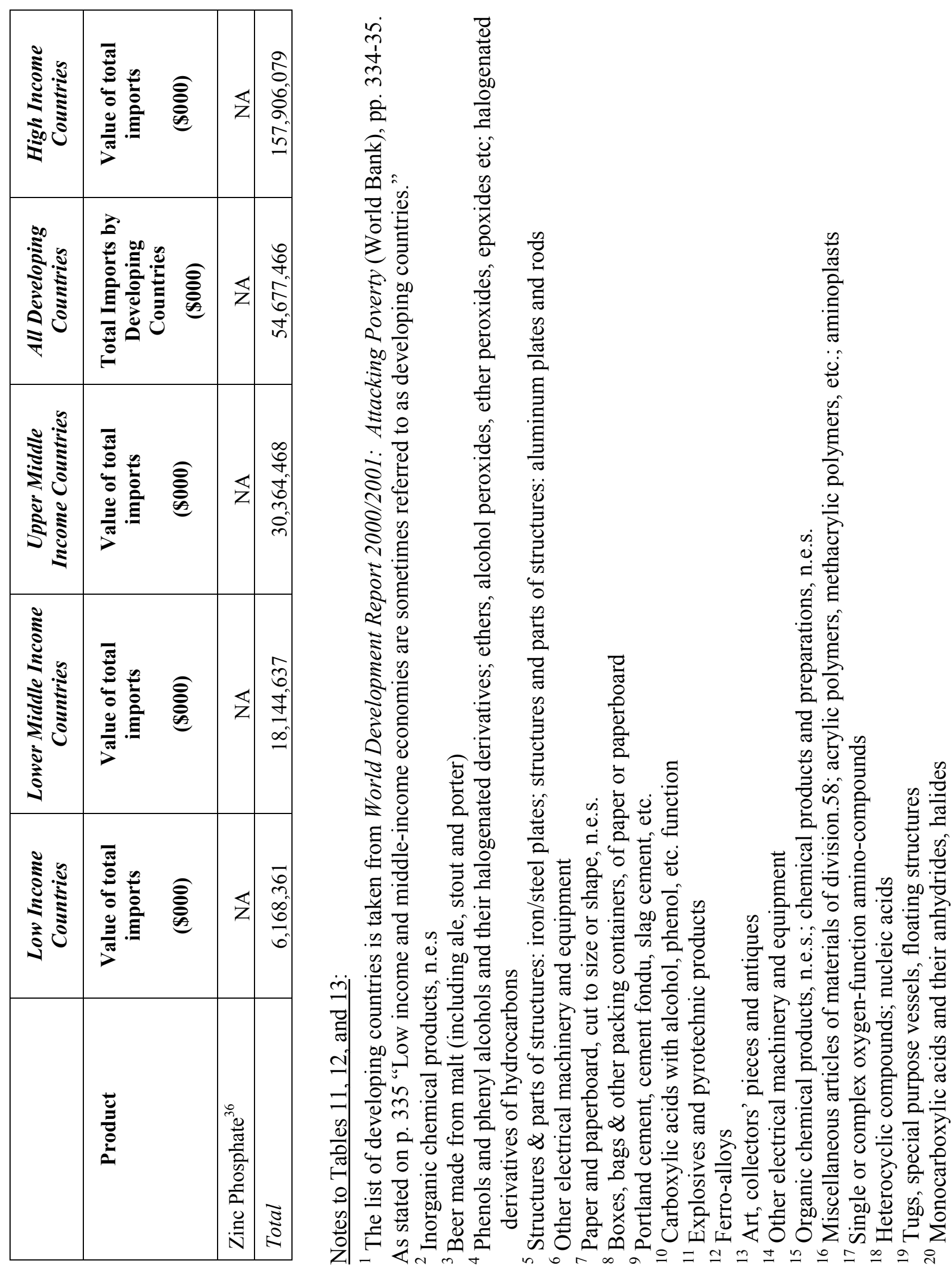


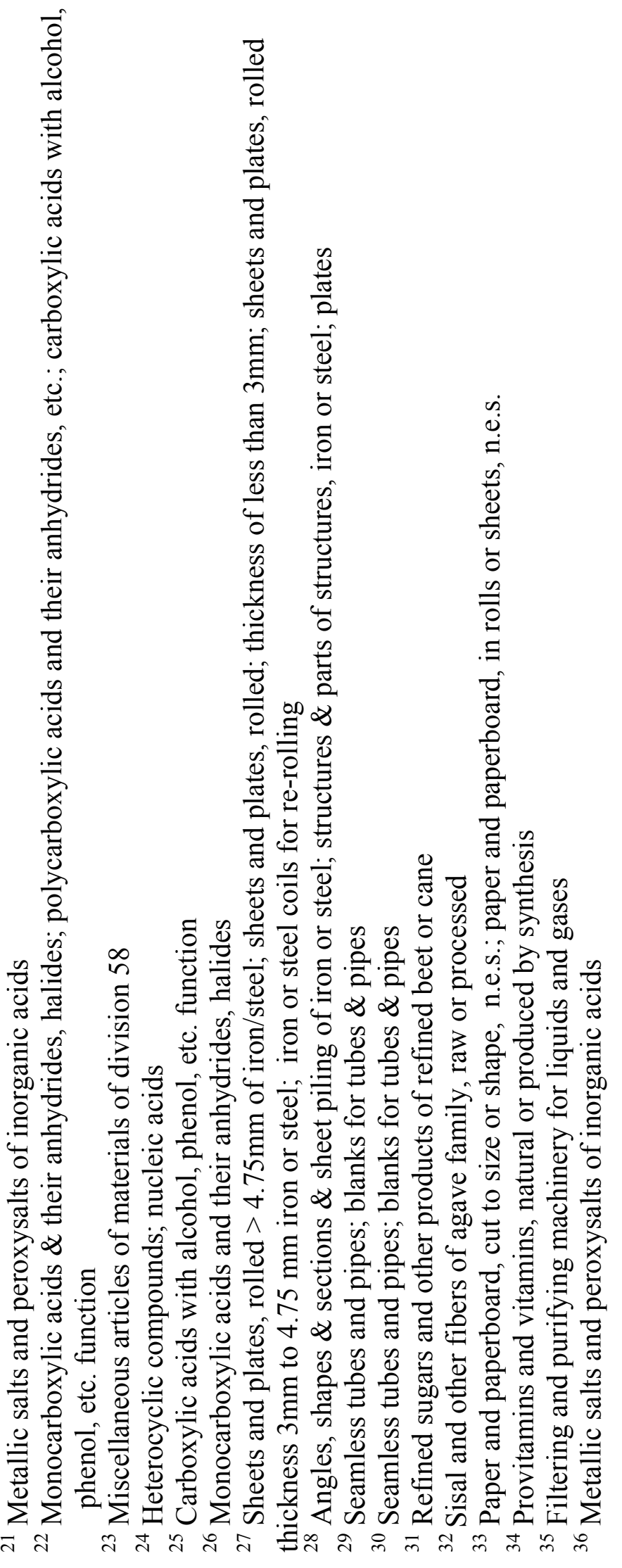




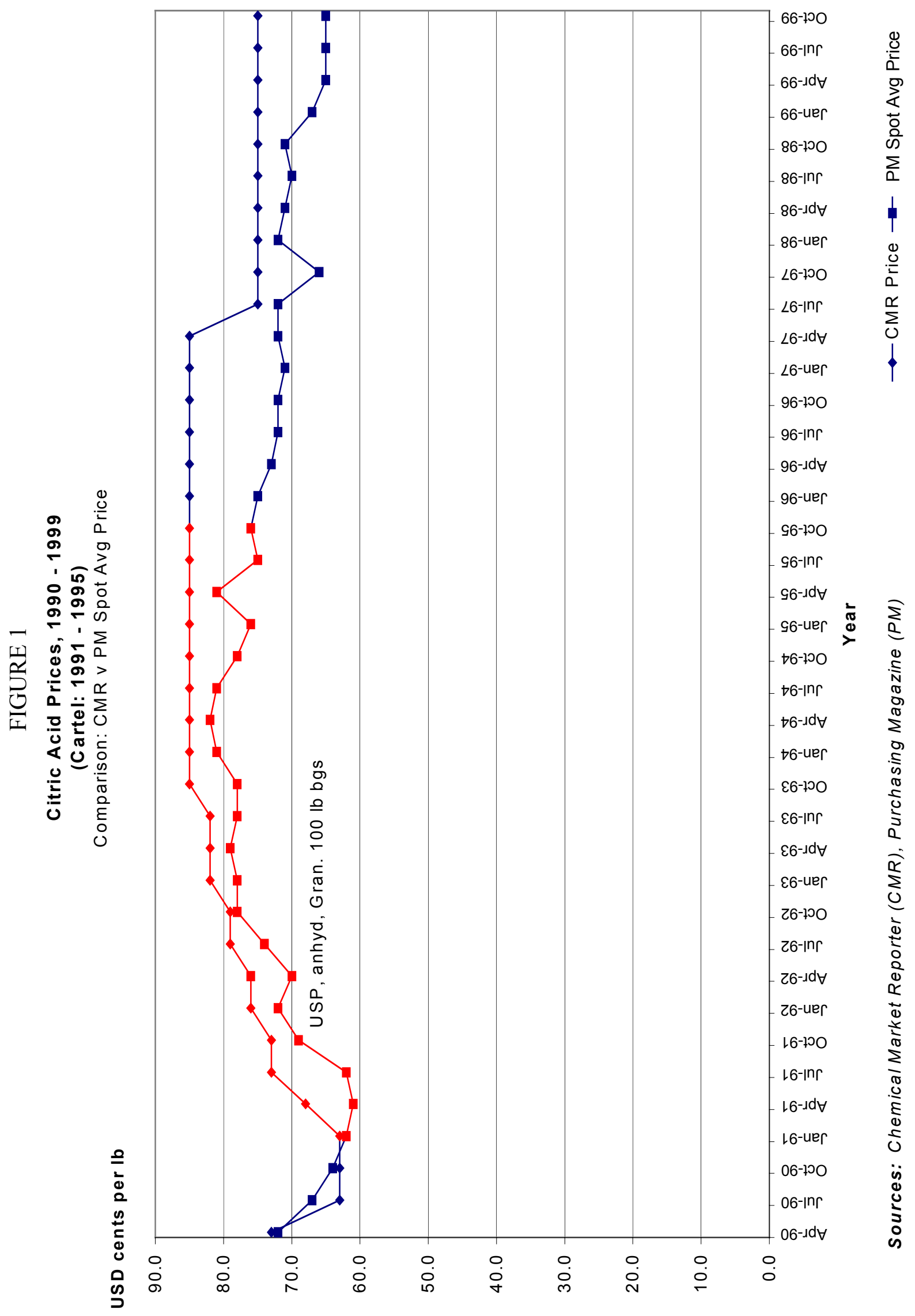




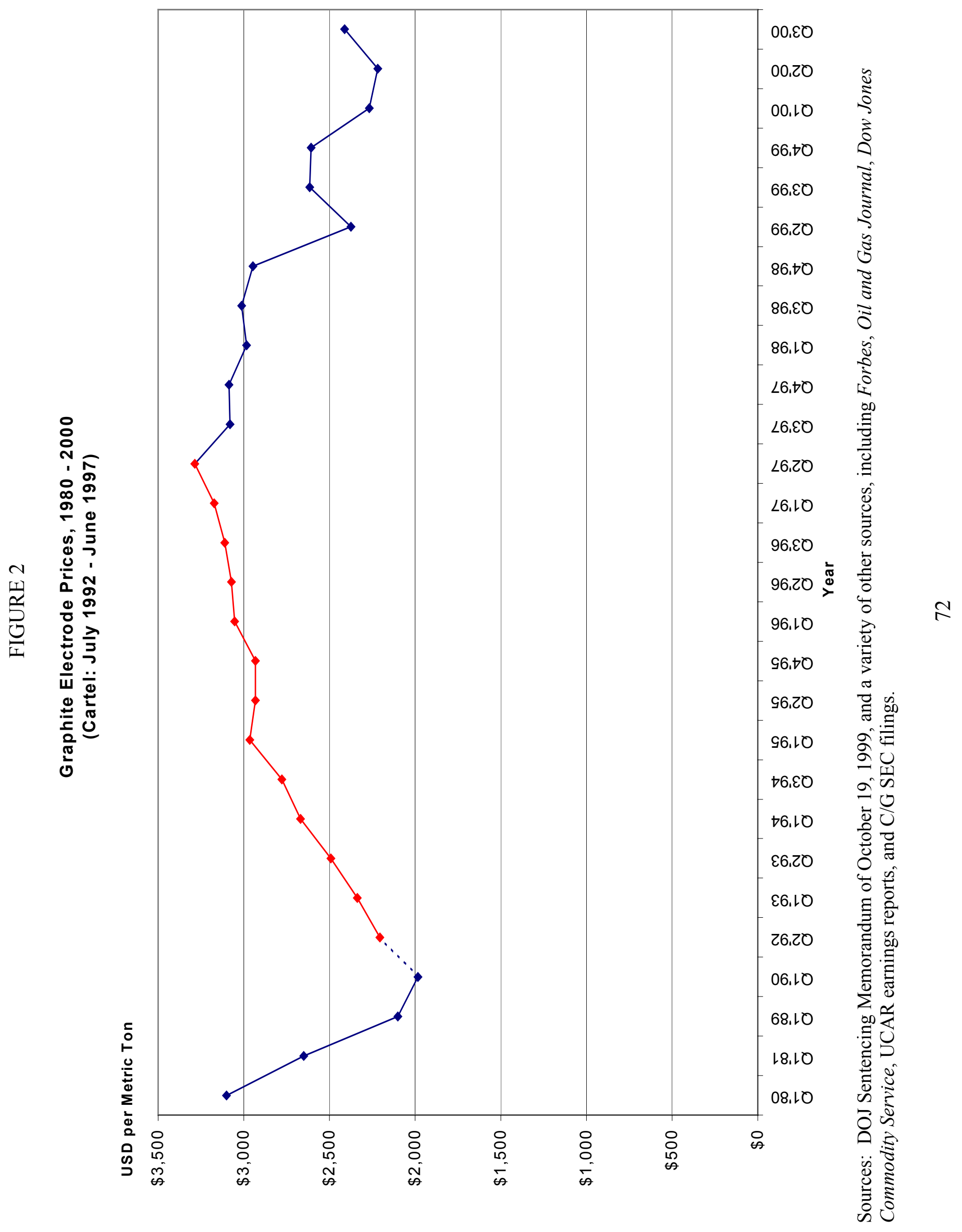




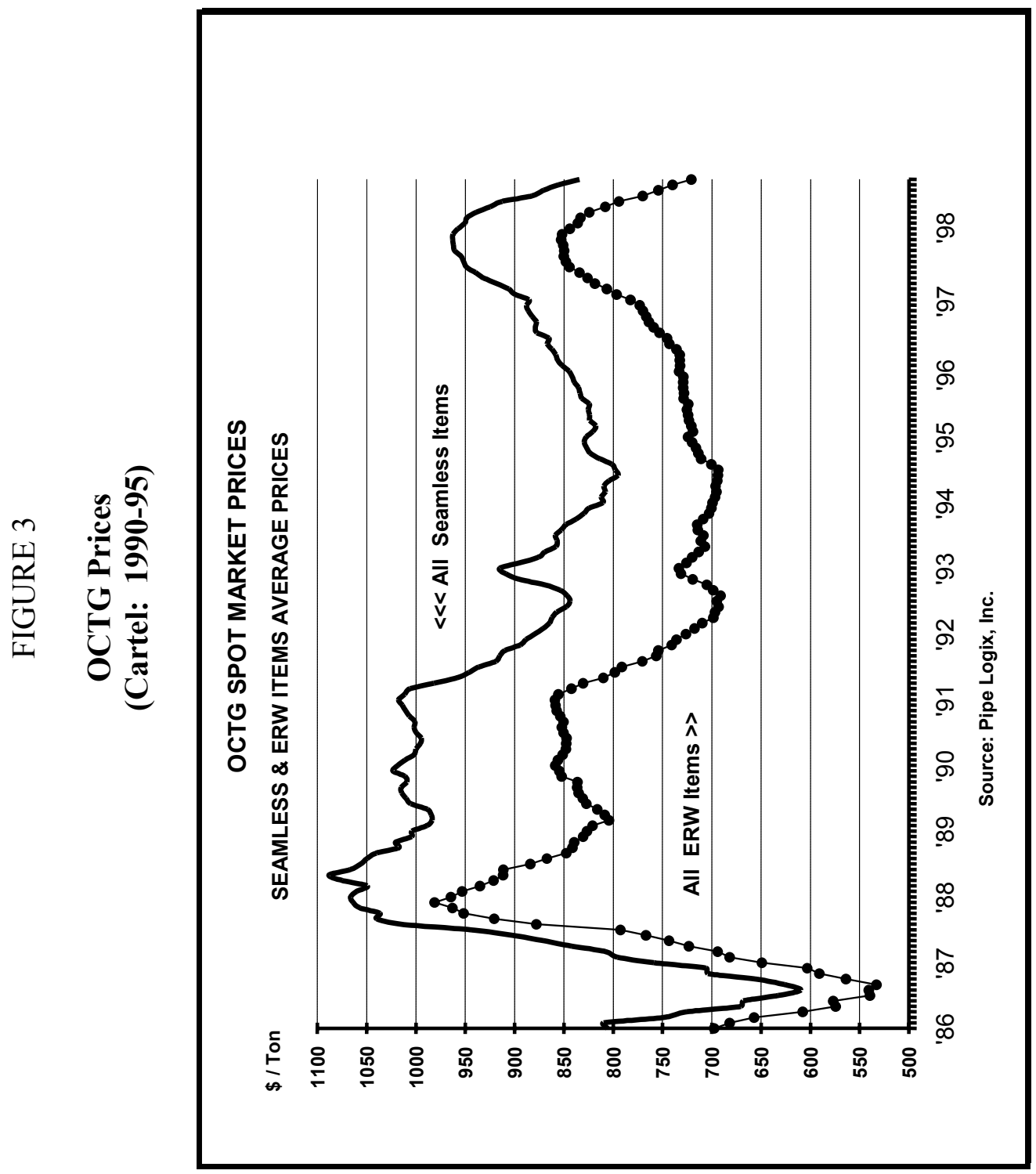




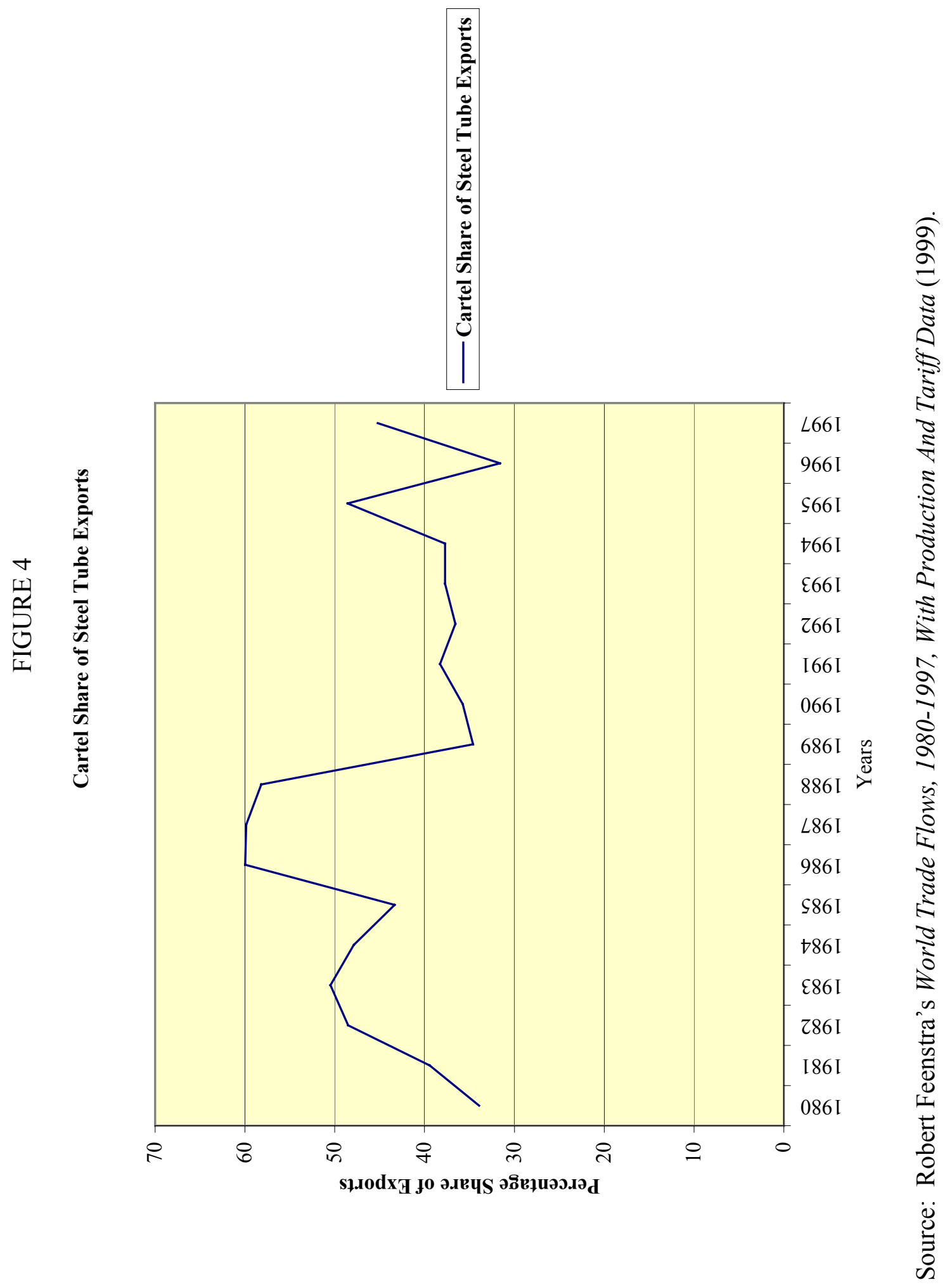

